\title{
Review \\ Genomic and Non-Genomic Regulatory Mechanisms of the Cardiac Sodium Channel in Cardiac Arrhythmias
}

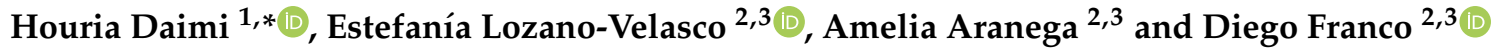 \\ 1 Biochemistry and Molecular Biology Laboratory, Faculty of Pharmacy, University of Monastir, \\ Monastir 5000, Tunisia \\ 2 Department of Experimental Biology, University of Jaen, 23071 Jaen, Spain; evelasco@ujaen.es (E.L.-V.); \\ aaranega@ujaen.es (A.A.); dfranco@ujaen.es (D.F.) \\ 3 Medina Foundation, Technology Park of Health Sciences, Av. del Conocimiento, 34, 18016 Granada, Spain \\ * Correspondence: daimihouria@gmail.com; Tel.: +216-25-223-446
}

check for updates

Citation: Daimi, H.; Lozano-Velasco, E.; Aranega, A.; Franco, D. Genomic and Non-Genomic Regulatory Mechanisms of the Cardiac Sodium Channel in Cardiac Arrhythmias. Int. J. Mol. Sci. 2022, 23, 1381. https:// doi.org/10.3390/ijms23031381

Academic Editors: Ademuyiwa S. Aromolaran and Brian P. Delisle

Received: 2 December 2021 Accepted: 6 January 2022

Published: 26 January 2022

Publisher's Note: MDPI stays neutral with regard to jurisdictional claims in published maps and institutional affiliations.

Copyright: (C) 2022 by the authors. Licensee MDPI, Basel, Switzerland. This article is an open access article distributed under the terms and conditions of the Creative Commons Attribution (CC BY) license (https:// creativecommons.org/licenses/by/ $4.0 /$ )

\begin{abstract}
Na}_{\mathrm{v}} 1.5$ is the predominant cardiac sodium channel subtype, encoded by the SCN5A gene, which is involved in the initiation and conduction of action potentials throughout the heart. Along its biosynthesis process, $\mathrm{Na}_{\mathrm{v}} 1.5$ undergoes strict genomic and non-genomic regulatory and quality control steps that allow only newly synthesized channels to reach their final membrane destination and carry out their electrophysiological role. These regulatory pathways are ensured by distinct interacting proteins that accompany the nascent $\mathrm{Na}_{\mathrm{v}} 1.5$ protein along with different subcellular organelles. Defects on a large number of these pathways have a tremendous impact on $\mathrm{Na}_{\mathrm{v}} 1.5$ functionality and are thus intimately linked to cardiac arrhythmias. In the present review, we provide current state-of-the-art information on the molecular events that regulate $S C N 5 A / \mathrm{Na}_{\mathrm{v}} 1.5$ and the cardiac channelopathies associated with defects in these pathways.
\end{abstract}

Keywords: cardiac sodium channel; gene regulation; cardiac arrhythmias

\section{Introduction}

The upstroke phase of the cardiac action potential (AP) is mainly coordinated by cardiac sodium channels, which are immediately activated and generate a fast $\mathrm{Na}^{+}$inward current, through the membrane, after membrane depolarization [1]. In atrial and ventricular myocytes, the sodium current $\left(I_{N a}\right)$ is principally governed by cardiac voltage-gated sodium channel $1.5\left(\mathrm{Na}_{\mathrm{v}} 1.5\right)$ with a tinny contribution of $\mathrm{Na}_{\mathrm{V}} 1.8$ [2]. The human $\mathrm{Na}_{\mathrm{v}} 1.5$ channel is composed of a pore-forming $\alpha$-subunit $(227-\mathrm{kDa})$ and one or more auxiliary $\beta$-subunit (30-kDa) [3]. SCN5A gene with $80 \mathrm{~kb}$ length is located on chromosome $3 \mathrm{p} 21$ and consists of 28 exons which encode a protein of 2016 amino acid, the $\alpha$-subunit of $\mathrm{Na}_{\mathrm{v}} 1.5$ channel [4]. This protein contains four homologous sites (DI-DIV), each composed of six transmembrane segments organized into two functional modules. Segments from one to four (S1-S4) generate the voltage-sensing module (VS), and segments five and six (S5-S6) jointly with P-loop create the pore module (PM). Finally, we can find an $\alpha$-helical S4-S5 linker, whose function is to bind these two structures, the voltage-sensing and the pore modules. Moreover, there are intracellular linkers that are in charge of DI-DII, DII-DIII, and DIII-DIV binding, and more concretely, the DIII-DIV linker is the controller of pore closing, acting as a fast inactivation gate [5]. The VS and PM modules of the $\mathrm{Na}_{\mathrm{v}} 1.5$ constitute preferred therapeutic targets for the treatment of several cardiac sodium channelopathies. Particularly, flecainide, as well as other class IC antiarrhythmic drugs, bind to the central cavity of the pore and block sodium permeation directly [5]. The class IA antiarrhythmic drugs (e.g., procainamide) and the class IB antiarrhythmic drugs (e.g., lidocaine) might act on a smaller surface of the central cavity of the pore as well [5]. However, polyunsaturated fatty acids (PUFAs) and PUFA analogs have been shown to be antiarrhythmic by inhibiting 
$\mathrm{Na}_{\mathrm{v}} 1.5$ channel currents, probably through acting on the voltage-sensing S4 segments that control inactivation in these channels $[6,7]$.

Since $S C N 5 A$ is transcribed to mRNA until $\mathrm{Na}_{\mathrm{v}} 1.5$ is assembled into the plasma membrane to exert its function, there are several steps with different proteins involved. SCN5A mRNA is translocated from the nucleus to the cytoplasm by the Nucleoporin 107 (Nup107) protein. It has been demonstrated that Nup107 is increased whenever a hypoxic and oxidative situation has a place in the heart tissue [8]. Once in the cytoplasm, SCN5A mRNA is translated to protein and assembled to $\beta 1-\beta 4$ subunits in the rough endoplasmic reticulum (ER), and subsequently, $\mathrm{Na}_{\mathrm{v}} 1.5$ protein is exported to the Golgi by the nuclear import protein, RAN guanine nucleotide release factor (MOG1), and Protein Kinase A [9-11]. It has been previously reported that the defect of MOG1- $\mathrm{Na}_{\mathrm{v}} 1.5$ interaction causes Brugada syndrome [9]. After protein glycosylation in Golgi, $\mathrm{Na}_{\mathrm{v}} 1.5$ is ready for anchoring into the intercalated discs (ID) for the AP transmission between cardiomyocytes, being responsible for the electro-mechanical coupling through gap junctions, adherens junctions, and desmosomes $[12,13]$. Moreover, AP is conducted through the lateral membrane (LM) due to localized $\mathrm{Na}_{\mathrm{v}} 1.5$ channels into T-tubules and in the focal adhesion complex or costameres that link adjacent myocytes in the myocardium through extracellular matrix interaction $[12,13]$. This process is characterized by the presence of specific proteins that control $\mathrm{Na}_{\mathrm{v}} 1.5$ trafficking and anchoring [13].

At the beginning of cardiac AP, the cell membrane is depolarized, and $\mathrm{Na}_{\mathrm{v}} 1.5$ channels are activated due to positively charged arginine or lysine residues in $\mathrm{S} 4$ segments. All four charged S4 segments change their position in the cell membrane with an outward movement, which leads to the opening of the channel pore, conducting to an inward $\mathrm{Na}^{+}$ current [14]. Few milliseconds later, the depolarization process generates "fast inactivation", where the $\mathrm{Na}_{\mathrm{v}} 1.5$ channel is closed and channel opening does not occur, due to an outward movement of S4 segments in domain III and IV, again. This dual role of the S4 segment is tightly integrated [15-20]. After a prolonged depolarization, P-loop and S5-S6 linker change their position with reference to the membrane, and $\mathrm{Na}_{\mathrm{v}} 1.5$ channels enter in a "slow inactivation", leading to the termination of the $\mathrm{Na}^{+}$current flow $[15,21]$.

At the end of its life cycle, $\mathrm{Na}_{\mathrm{v}} 1.5$ is degraded by proteasome and autophagic degradation pathways [11].

\section{Genomic Regulation of the Cardiac Sodium Channel}

\subsection{Genetic Code of SCN5A}

$\mathrm{Na}_{\mathrm{v}} 1.5$ channel expression and function may be impaired due to variations in the genomic sequence of $S C N 5 A$, including missense, nonsense, splice-altering, and frame shift truncation $[22,23]$. These variations cause different cardiac diseases because of a loss- or gain-of-function and occasionally both, generating overlapped phenotypes [24]. For example, Brugada Syndrome (BrS) [24-26], progressive cardiac conduction disease (Lev-Lenegre disease) $[27,28]$, and sick sinus syndrome [29,30] are some diseases caused by loss-of-function mutations in SCN5A. However, long QT syndrome type 3 (LQTS3) [24,31] and multifocal ectopic Purkinje-related premature contractions (MEPPC) [32-34] are due to gain-of-function mutations in SCN5A. Finally, a combination of gain- and loss-of-function mutations are associated with atrial fibrillation (AF) $[35,36]$ and dilated cardiomyopathy (DCM) [34,36-38]. Some of these channelopathies are widely described in Section 4 of this review. Additionally, several SCN5A missenses can generate dominant-negative variants affecting $\mathrm{Na}_{\mathrm{v}} 1.5$ trafficking or gating at the cell surface [39-41]. A recent study demonstrated that most of $S C N 5 \mathrm{~A}$ missense that generate loss-of-function variants exert a dominant-negative effect that confers a high burden of BrS [42]. Finally, post-translational modifications affecting $\mathrm{Na}_{\mathrm{v}} 1.5$ have an impact on the use of antiarrhythmic drugs, making these data quite relevant for future drug design [43]. 


\subsection{Regulation of SCN5A Transcription}

2.2.1. Epigenetic Regulation of $S C N 5 A$

Regulation of SCN5A by Distinct Regulatory Elements and Histones

Gene transcriptional activation is not only modulated by transcription factors; in this process, the role of distinct regulatory elements (RE) is also important, as well as how these REs interact with chromatin, depending on DNA accessibility. Several authors have identified different roles of an enhancer cluster in the SCN5A-SCN10A locus, which modulate SCN5A gene expression [44-46]. RE-1 and RE-5 are located in an SCN10A and SCN5A intron, respectively, and RE-6, located downstream of $S C N 5 A$, contains genetic variants associated with PR intervals and QRS duration [44,45,47,48]. Moreover, Christoffels' lab [49] has recently demonstrated that there are several downstream SCN5A REs acting as cardiacspecific "super enhancers", concretely the intergenic region composed by RE6-9, which possess an extensive association with Histone H3 lysine (K) 27 acetylation (H3K27ac) [50]. RE6-9 has the ability to fine-tune Scn5a-Scn10a chromatin architecture modulating Scn5a expression. In addition, it has been identified that some single-nucleotide polymorphisms (SNPs) located in an enhancer region are able to regulate transcription factor binding and modulate gene expression. In particular, major alleles of rs6801957 and rs10428132 lead to SCN5A gene expression, while minor alleles cannot due to a loss of a T-box protein binding site [51,52]. Furthermore, an enrichment of H3K27ac and Histone H3 lysine (K) 4 trimethylation (H3K4me3) near of $S C N 5 A$ promoter region in striated muscles regulates normal expression of $S c n 5 a$ and improve the re-expression of $S C N 5 A$ in denervated muscle $[49,53,54]$. Moreover, Lamin A/C (encoded by LMNA) is a component of the nuclear lamina, and its K219T mutation has been described to trigger a change in the distribution of the histone marks. Concretely, H3K9me and H3K27me, which are transcriptional repressive histone marks, and $\mathrm{H} 3 \mathrm{~K} 4 \mathrm{me} 3$, which acts as transcriptional active histone mark, generate cardiac conduction defects through $S C N 5 \mathrm{~A}$ inhibition and reduced $I_{N a}$ density [55].

\section{Regulation of SCN5A by Transcription Factors}

During biosynthesis, SCN5A transcription is regulated by several transcription factors. Sometimes this transcription step can be enhanced or decreased, i.e., TBX5 has a binding site downstream of the SCN5A gene, and several authors have demonstrated that TBX5 knockout presents a decreased density of $\mathrm{Na}_{\mathrm{v}} 1.5$ that leads to arrhythmias and eventually sudden cardiac death [56-58]. Additionally, GATA4 and GATA5 have their binding site in the $S C N 5 A$ promoter and intron 1 region. These transcription factors activate the SCN5A gene in human left ventricles, whereas heterozygous mutants for GATA $4^{+}{ }^{-}$show short PR intervals [59-61]. Moreover, MEF2C has its binding site in the SCN5A promoter region and enhances $S C N 5 A$ transcription $[62,63]$. Finally, IRX3 gain-of-function upregulates SCN5A mRNA levels $[64,65]$, whereas, on the contrary, FOXO1 and Snail negatively regulate SCN5A mRNA levels [66-70] (Figure 1).

\subsubsection{Post-Transcriptional Regulation of $S C N 5 A$ Regulation of SCN5A by Alternative Splicing}

After transcription, precursor mRNA copes with splicing and post-transcriptional modification to generate mature mRNA and finally translation into protein. Alternative splicing generate multiple functional $\left(\mathrm{Na}_{\mathrm{v}} 1.5 \mathrm{a}, \mathrm{Na}_{\mathrm{v}} 1.5 \mathrm{~d}, \mathrm{Na}_{\mathrm{v}} 1.5 \mathrm{e}\right.$, and $\left.\mathrm{Na}_{\mathrm{v}} 1.5 \mathrm{c}\right)$ and nonfunctional $\left(\mathrm{Na}_{\mathrm{v}} 1.5 \mathrm{~b}, \mathrm{Na}_{\mathrm{v}} 1.5 \mathrm{f}\right.$, and truncated) $\mathrm{Na}_{\mathrm{v}} 1.5$ variants [11]. $\mathrm{Na}_{\mathrm{v}} 1.5 \mathrm{a}$ isoform is characterized by the deletion of exon 18. This isoform is only present in small rodents and, compared with full-length $\mathrm{Na}_{\mathrm{v}} 1.5$, leads to altered electrophysiological kinetics properties. There is no evidence of $\mathrm{Na}_{\mathrm{v}} 1.5 \mathrm{a}$ expression in human cardiac cells [11,71]. Another alternative spliced variant of $S C N 5 A$ generates $\mathrm{Na}_{\mathrm{V}} 1.5 \mathrm{c}$ isoform, which has been identified as the most abundant isoform in humans. $\mathrm{Na}_{\mathrm{v}} 1.5 \mathrm{c}$ is characterized by a $5^{\prime}$-trinucleotide deletion in exon 18, concretely a CAG-Glu (Q) in 1077 position, affected by the splicing machinery and generating a $\mathrm{Na}_{\mathrm{v}} 1.5$ variant that contains 2015 polypeptides instead of 2016 . It has been identified that the electrophysiological properties of $\mathrm{Na}_{\mathrm{v}} 1.5$ and $\mathrm{Na}_{\mathrm{v}} 1.5 \mathrm{c}$ are 
indistinguishable [71,72]. $\mathrm{Na}_{\mathrm{v}} 1.5 \mathrm{~d}$ is another $\mathrm{Na}_{\mathrm{v}} 1.5$ variant, where $120 \mathrm{bp}$ fragment is deleted from exon 17. This $\mathrm{Na}_{\mathrm{v}} 1.5 \mathrm{~d}$ isoform is present in the fetal and adult human heart and has altered channel kinetics due to a reduction of open channel probability $[71,73,74]$. Finally, the last functional $\mathrm{Na}_{\mathrm{v}} 1.5$ variant is $\mathrm{Na}_{\mathrm{v}} 1.5 \mathrm{e}$ and is generated by alternative splicing on exon 6. It can be found $\mathrm{Na}_{\mathrm{v}} 1.5$ e with $5^{\prime}$-exon 6 in neonatal (exon $6 \mathrm{a}$ ) or $3^{\prime}$-exon 6 (exon 6b) in any adult mammalian heart $[4,75]$. $\mathrm{Na}_{\mathrm{v}} 1.5 \mathrm{e}$ contains a $\mathrm{K} 211$ residue, instead of D211 residue in $\mathrm{Na}_{\mathrm{v}} 1.5$, being responsible for slower kinetics of the channel [76]. $\mathrm{Na}_{\mathrm{v}} \mathrm{d} 1.5 \mathrm{~b}$ is a non-functional $\mathrm{Na}_{\mathrm{v}} 1.5$ variant and is generated by the deletion of exon 17 and exon 18 . Heterologous expression reveals that exon 17 encodes an essential $\mathrm{Na}_{\mathrm{v}} 1.5$ region that confers functionality to the channel $[74,77]$. This splice variant is present in mouse hearts, but there is no evidence of this variant in other mammals' hearts [74]. On the other hand, deletion of exon 24 of $\mathrm{Na}_{\mathrm{v}} 1.5$ generates $\mathrm{Na}_{\mathrm{v}} 1.5 \mathrm{f}$ variant; this isoform is highly detected in rat heart and human brain but not in the human heart [78,79]. Electrophysiological experiments evidenced that $\mathrm{Na}_{\mathrm{V}} 1.5 \mathrm{f}$ is a non-functional variant [71]. Finally, it has been identified three C-terminal truncated spliced variants, E28B, E28C, and E28D, that generate reduced protein levels and no functional $\mathrm{Na}^{+}$currents in the normal fetal and adult human heart [80]. In another layer of complexity, in a very recent study, it has been evidenced that minor introns modulate gene families at a post-transcriptional level. Concretely, U6actac, which is a minor spliceosome component, modulates $\mathrm{Na}_{\mathrm{v}} 1.5$ and $\mathrm{Ca}_{\mathrm{v}} 1.2$ protein levels through the removal of minor introns in Scn5a and Cacna1c, regulating electrophysiological properties of cardiomyocytes [81].

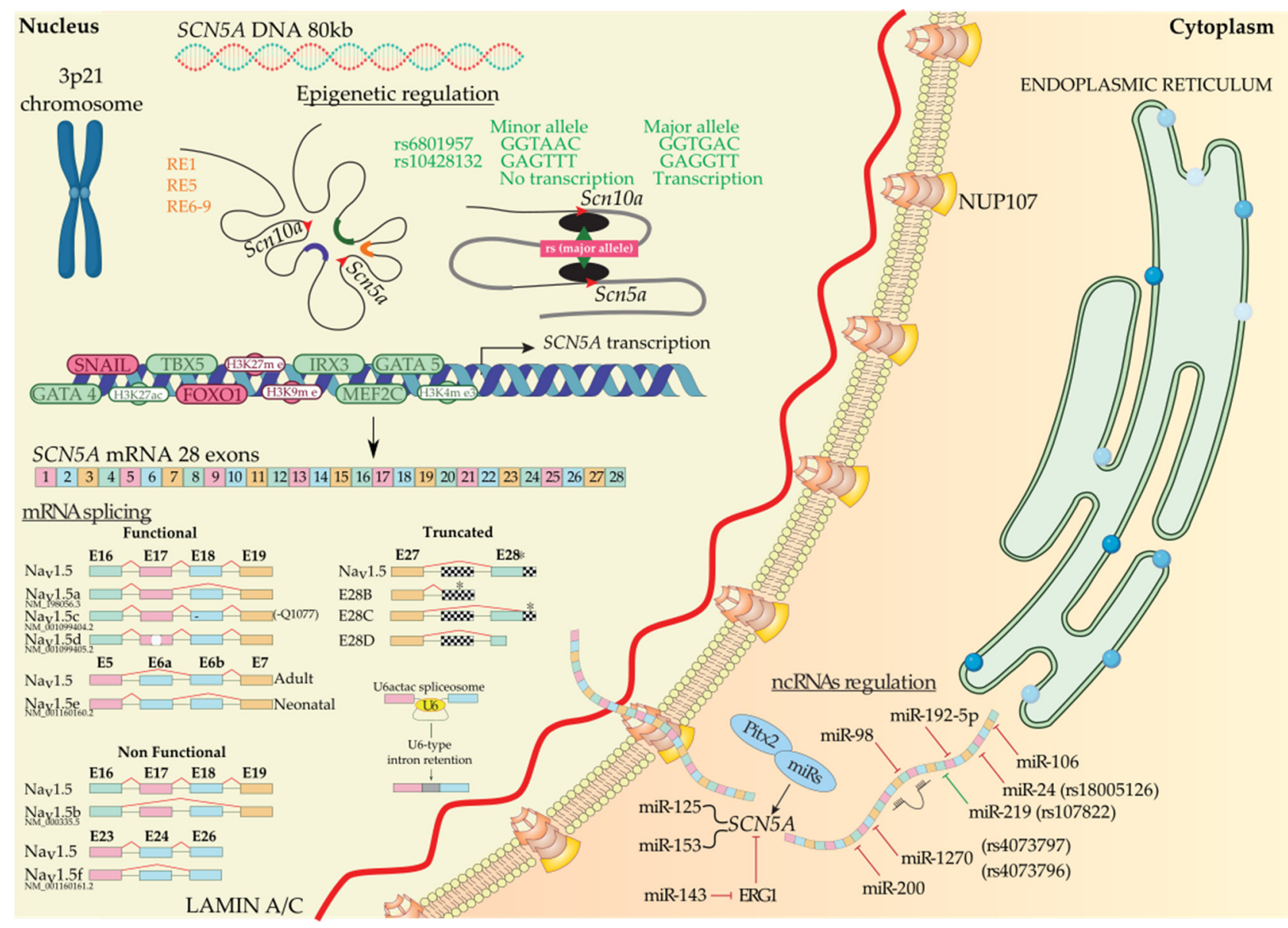

Figure 1. SCN5A biosynthesis: chromosomal localization, gene transcriptional activation modulated by regulatory elements, transcription factors, histones, and SNPs. Functional, non-functional, and truncated isoforms derived from mRNA splicing, mechanism of the U6-type intron retention, and post-transcriptional regulation mediated by ncRNAs. Alternative exon sequences, intronic or exonic sequences outside the open reading frame (squared), and stop codons (asterisks) are indicated. 


\section{Regulation of SCN5A by Non-Coding RNAs}

SCN5A mRNA degradation or translational repression can be mediated by microRNAs. It has been widely demonstrated that microRNAs exert their function controlling the development of several cardiac arrhythmogenic diseases; however, there is not much information about the $S C N 5 A / \mathrm{Na}_{\mathrm{v}} 1.5$ post-transcriptional control by microRNAs despite being an important modulator of cardiac arrhythmias [82-85]. A few years ago, data from our laboratory demonstrated that miR-98, miR-106, miR-200, and miR-219 directly regulated human SCN5A, while miR-125 and miR-153 regulate it indirectly, being evidenced that miR219 and miR200 modulate Scn5a expression in an opposite way in HL1 cardiomyocytes. Concretely, miR-200 decreases, while miR-219 increases Scn5a expression. Moreover, miR-219 is able to increase $\mathrm{Na}_{\mathrm{v}} 1.5$ protein levels leading to the subsequent rise in $I_{\mathrm{Na}}$ [86]. In another study, we elucidated a complex regulatory network where Pitx2 transcription factor and microRNAs are involved, being able to modulate ion channel expression in atrial fibrillation [87-89]. Additionally, Zhao et al. [90] demonstrated that miR-192-5p exerts its function, reducing $\mathrm{Na}_{\mathrm{v}} 1.5$ expression and $I_{\mathrm{Na}}$ density in humans. It has also been evidenced that $S C N 5 A$ expression can be indirectly modulated through ERG1 mediated regulation by miR-143 [91]. Furthermore, a miR-24 binding site is generated in the coding sequence of SCN5A by the SNP rs1805126, decreasing SCN5A expression and $I_{N a}$ density [92]. Finally, it has been evidenced that some SNPs can generate new miRNAs binding sites at the SCN5A $3^{\prime}$ UTR region. Previous work in our lab demonstrated that rs4073797 and rs4073796 polymorphisms create a new miR-1270 binding site in SCN5A 3'UTR, which imbalance Scn5a expression. Moreover, rs107822C localized upstream of miR-219a precursor impairs miR-219a expression deregulating $S C N 5 A / \mathrm{Na}_{\mathrm{v}} 1.5$ levels [93]. Although $I_{\mathrm{Na}}$ is the most relevant during cardiac $\mathrm{AP}$, the functional role of microRNAs controlling SCN5A expression is poorly described. Quite recently, a new class of RNAs has emerged, i.e., long non-coding RNAs (lncRNAs), which are long RNA molecules with $>200 \mathrm{nt}$ length and scarce protein-coding properties, but being able to modulate several biological processes and thus participating in pathogenesis [94,95]. It has been demonstrated that some lncRNAs modulate cardiac AP regulating the slow component of the delayed rectifier potassium current $\left(I_{K S}\right)$ or transient outward potassium current $\left(I_{t o}\right)$, concretely, IncRNA-Kcna2as and lncRNA-MALAT1, respectively [96,97], and more recently, it has been elucidated that $\ln \mathrm{DACH} 1$ modulate $\mathrm{Na}_{\mathrm{v}} 1.5$ protein distribution through dystrophin binding which determines $\mathrm{Na}_{\mathrm{v}} 1.5$ membrane anchoring [98]. Studies about how cardiac AP can be modulated by lncRNA need to be further developed, as these molecular mechanisms could reveal a potential therapeutic work line.

\section{Non-Genomic Regulation of the Cardiac Sodium Channel}

Being an ion channel, $\mathrm{Na}_{\mathrm{v}} 1.5$ is first synthesized as a primary protein chain that is subsequently folded in order to acquire the pore-forming three-dimensional conformation [11]. This tertiary structure is then assembled with its beta subunits, most likely $(\beta 1)$, and trafficked through the Golgi apparatus to be targeted to the corresponding cell membrane compartments [99]. Along this whole process, $\mathrm{Na}_{\mathrm{v}} 1.5$ went through distinct non-genomic regulatory modifications and quality control steps conferring its unique conformational and functional identity as a voltage-gated sodium channel [11,100]. These steps are ensured by a growing set of regulatory proteins that have been demonstrated to covalently or non-covalently interact with $\mathrm{Na}_{\mathrm{v}} 1.5$ [101]. In addition to the interacting proteins, $\mathrm{Na}_{\mathrm{v}} 1.5$ function has been demonstrated to be influenced by wider intracellular (oxidative stress, metabolic stress, electrolyte homeostasis, etc.) and extracellular $(\mathrm{pH}$, temperature, hormones, etc.) factors. All these factors are discussed subsequently in this review. 


\subsection{Regulation of $\mathrm{Na}_{v} 1.5$ Biosynthesis and Post-Translational Modifications}

3.1.1. Regulation of $\mathrm{Na}_{\mathrm{v}} 1.5$ Translation and ER Retention

The translation of $\mathrm{Na}_{\mathrm{v}} 1.5$ starts in the cytosol and then pursue into the endoplasmic reticulum (ER). Anchoring the ribosome with the elongating $\mathrm{Na}_{\mathrm{v}} 1.5$ polypeptide chain to the ER occurs when a signal peptide is recognized by the signal recognition particle (SRP) that targets the active ribosome to the rough endoplasmic reticulum (ER) membrane. Unlike cytosolic proteins, which have their signal peptide generally within the amino terminal, ion channels contain numerous signal sequences that are not restricted to the amino terminal [102]. Although the signal sequences of some ion channels such as Kv1.3 and CFTR have been already mapped to the second transmembrane spanning domain, almost 200 amino acids downstream from the $\mathrm{NH}_{2}$ terminal [102], that of $\mathrm{Na}_{\mathrm{v}} 1.5$ are not yet identified. Once anchored, the ribosome translocates the elongating polypeptide chain into the ER lumen [103]. As a transmembrane protein, the nascent $\mathrm{Na}_{\mathrm{v}} 1.5$ is soon pushed to the ER membrane, where it is anchored and retained [103]. The ER retention is thought to occur when specific ER retention motifs embedded in the elongating $\mathrm{Na}_{\mathrm{v}} 1.5$ polypeptide (most likely in the DI-DII linker of the sodium channel [104]) binds a cytosolic signal recognition particle (endoplasmic reticulum recognition particle, ERRP), that then directs the $\mathrm{Na}_{\mathrm{v}} 1.5$-ERRP complex to receptors within the ER membrane [105-107]. The complex $\mathrm{Na}_{\mathrm{v}} 1.5$-ERRP is then trapped within the ER, ensuring that the newly formed channel does not leave the ER membrane before finishing the folding and assembly steps [102]. At this level, several regulatory proteins and residues are reported to bind to this complex and facilitate the folding and maturation of the nascent protein [11,102,105-110] (Figure 2).

The correct folding of the newly synthesized $\mathrm{Na}_{\mathrm{v}} 1.5$ channels is commonly thought to be a condition for their forward trafficking to the cell membrane and their proper gating function. This notion has been tested by the exploration of $\mathrm{Na}_{\mathrm{v}} 1.5$ trafficking-deficient mutants such as R282H, A124D, and V1378M that, due to folding defects, they failed to exit the ER and thus to reach the cell membrane [111,112]. Although the importance of this step in the life cycle of any ion channel, very scarce information is currently available about the mechanism of $\mathrm{Na}_{\mathrm{v}} 1.5$ folding and its regulation. Nonetheless, it is currently established that one of the prerequisites for proper $\mathrm{Na}_{\mathrm{v}} 1.5$ folding is core-glycosylation, as will be discussed later in this review [113]. In addition, molecular chaperone proteins such as protein disulfide isomerases (PDI), ER oxidoreductases (ERO), $70 \mathrm{kDa}$ heat shock proteins (Hsp70), $90 \mathrm{kDa}$ heat shock proteins (Hsp90), as well as calnexin and calreticulin, have been demonstrated to regulate the folding of the nascent proteins and the ER-associated degradation of the misfolded proteins [114-118]. However, their implication in the $\mathrm{Na}_{\mathrm{v}} 1.5$ folding process has not been specifically studied yet. Interestingly, $\mathrm{Na}_{\mathrm{v}} 1.5 \mathrm{H} 558 \mathrm{R}$ polymorphism has been shown to have a corrective effect on the misfolded $\mathrm{R} 282 \mathrm{H}$ mutant by restoring its trafficking to the cell membrane and thus limiting the misfolding of the mutant through a physical interaction $[111,119]$.

Some antiarrhythmic drugs such as mexiletine, quinidine, and flecainide proved their efficiency rescuing the trafficking of some misfolded $\mathrm{Na}_{\mathrm{v}} 1.5$ variants, thus playing the role of pharmacological chaperones [112,120]. In addition, curcumin, a major constituent of turmeric known to block the ER calcium pump, has also been reported as effective in rescuing the $I_{N a}$ current of L325R misfolded $\mathrm{Na}_{\mathrm{v}} 1.5$ channels [40]. Low temperature has also been demonstrated to trigger the rescue of misfolded $\mathrm{Na}_{\mathrm{v}} 1.5$ mutants [120], probably through slowing the folding process, which prevents protein misfolding and aggregation [121]. 


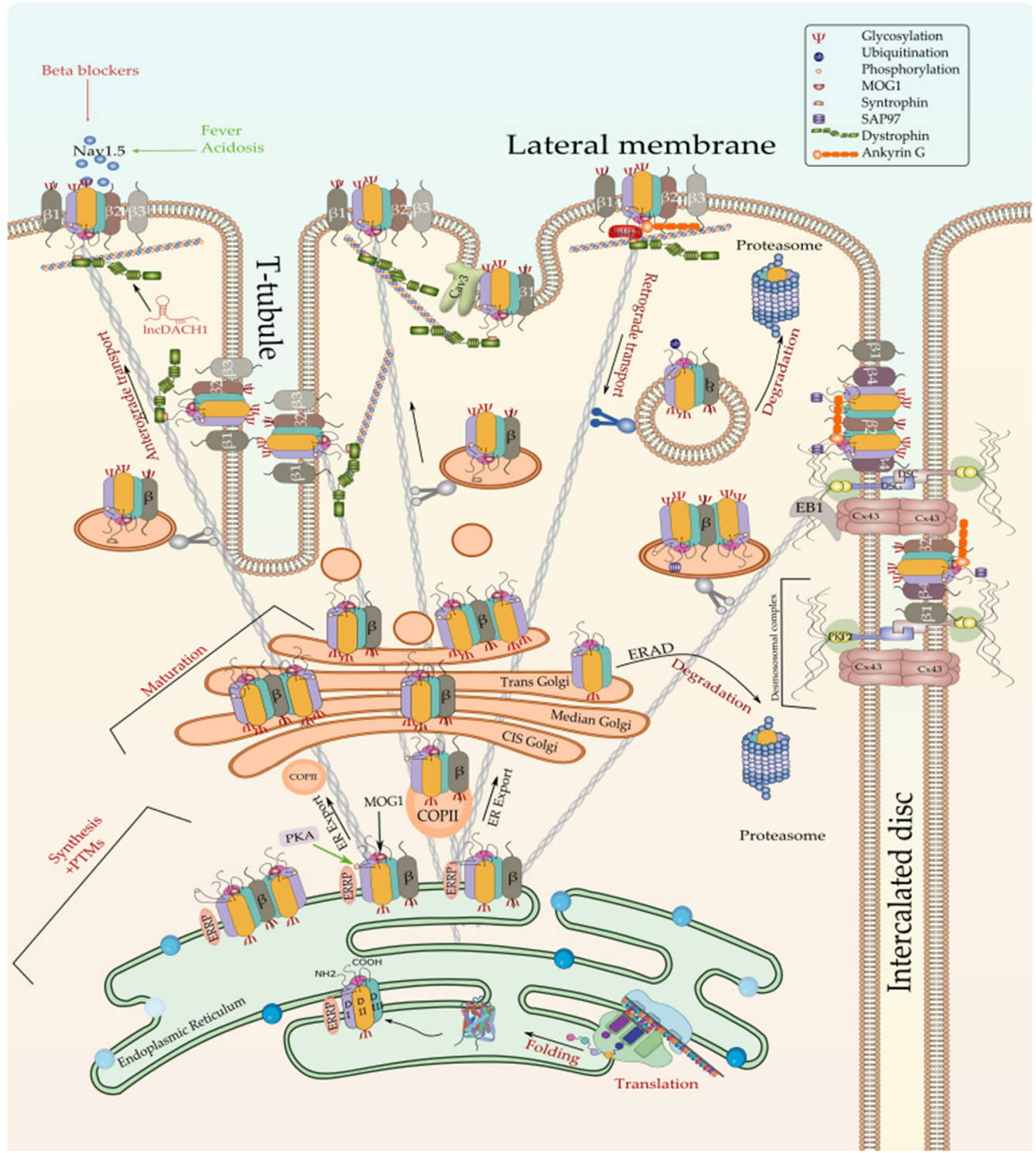

Figure 2. Biosynthesis and degradation pathways of $\mathrm{Na}_{\mathrm{v}}$ 1.5. Only one of the possible scenarios where $\mathrm{Na}_{\mathrm{v}} 1.5$ assembles with one or more $\beta$-subunits early at the ER is depicted here. Furthermore, one possible scenario where ERAD-dependent degradation exclusively affects $\alpha$ subunit rather than $\alpha-\beta$ assembly is shown here since no information is currently available about the detailed process. ERRP — endoplasmic reticulum retention protein; $\beta$ — beta subunit; PKA—protein kinase A; MOG1RAN guanine nucleotide release factor; COPII—coat protein complex II; ERAD—ER-associated degradation; Cx43-connexin 43; PKP2-plakophilin 2; DSG-desmoglein; DSC-desmocollin; EB1-end-binding 1; Cav3-caveolin 3; PTMs-post-translational modifications.

\subsubsection{Co-Translational and Post-Translational Regulation of $\mathrm{Na}_{\mathrm{v}} 1.5$} $\mathrm{N}$-Linked Glycosylation of Nascent $\mathrm{Na}_{\mathrm{v}} 1.5$

One of the earliest modifications that the $\mathrm{Na}_{\mathrm{v}} 1.5$ undergoes co-translationally once inserted into the ER is the $\mathrm{N}$-glycosylation $[99,113]$. This quality control step has been first evidenced in the rat heart by Cohen and Levitt, who have found that glycosylation increases $\mathrm{Na}_{\mathrm{v}} 1.5$ mass by only $5 \%$, compared to $25-30 \%$ increases observed in other voltage-gated sodium channel isoforms [122]. Glycosylation initiates in the ER and terminates in the Golgi $[113,123]$. In the ER, glycosylation initiates when glycan (Glc3Man9GlcNAc2) is dissociated from a lipid derivative by oligosaccharyl transferase (OST) and bind to the amide nitrogen of asparagine $(\mathrm{N})$ localized in the extracellular side of the nascent $\mathrm{Na}_{\mathrm{v}} 1.5$ 
protein $[100,124]$. Although no validated "map" of the N-glycosylation sites has been published yet for $\mathrm{Na}_{\mathrm{v}} 1.5,13$ potential external $\mathrm{N}$-glycosylation sites have been identified in human $\mathrm{Na}_{\mathrm{v}} 1.5$ [125], and at least 14 putative $\mathrm{N}$-linked glycosylation sites have been reported in the rat cardiac sodium channel [122]. The N-glycosylation of the newly formed cardiac sodium channel has been reported to be a prerequisite for proper $\mathrm{Na}_{\mathrm{v}} 1.5$ folding and subsequent surface expression as well as an assembly with its $\beta$ subunits $[99,113,126]$. According to Arakel et al., $\mathrm{Na}_{\mathrm{v}} 1.5$ maturation strongly depends on the presence of the auxiliary $\beta 1$ that binds to the pore-forming $\alpha$ subunit and promotes its glycosylation and its trafficking to the cell membrane [127].

In this context, $\mathrm{N}$-glycosylated $\mathrm{Na}_{\mathrm{v}} 1.5$ is thought to undergo subsequent serial deglucosylation steps and extreme quality controls involving the ER-resident chaperones, which will ensure that only correctly folded and fully glycosylated channels can be trafficked $[113,123,128]$. Interestingly, Mercier et al. found that early $\mathrm{N}$-glycosylated $\mathrm{Na}_{\mathrm{v}} 1.5$ channels generated in the ER could reach the cell membrane through an unconventional trafficking pathway bypassing the Golgi stacks while functional channels are trafficked through the conventional pathway that is Golgi-dependent [113]. In addition, ER-resident chaperones such as Calnexin and Calreticulin have been reported to play a crucial role in controlling ion channels folding and efficient export to the Golgi [129-131]. However, there is no evidence of physical interaction of Calnexin and $\mathrm{Na}_{\mathrm{v}} 1.5$ despite their proven co-localization in the ER [132,133]. While properly folded $\mathrm{Na}_{\mathrm{v}} 1.5$ are trafficked forward to the cis-Golgi where they will be fully maturated, misfolded $\mathrm{Na}_{\mathrm{v}} 1.5$ are retained in the ER to be later degraded, most likely through the activation of the unfolded protein response (UPR) pathway and/or ER-associated degradation (ERAD) pathway that is linked to the cytoplasmic ubiquitin-proteasome pathway [134-136].

\section{Phosphorylation and Dephosphorylation of $\mathrm{Na}_{\mathrm{v}} 1.5$}

In addition to $\mathrm{N}$-linked glycosylation, $\mathrm{Na}_{\mathrm{v}} 1.5$ undergoes phosphorylation as a posttranslational modification [137]. Thirty years ago, Shubert et al. brought the first evidence of $\mathrm{Na}_{\mathrm{v}} 1.5$ phosphorylation by protein kinase A (PKA) through the activation of the $\beta$ adrenergic system by isoproterenol, which led to an increased level of cAMP, which in turn reduced $\mathrm{Na}^{+}$current $\left(I_{\mathrm{Na}}\right)$ [138]. These findings were further confirmed by a subsequent study by Frohnwieser and his co-worker, who showed that combined cytosolic injection of cAMP and a PKA activator increased $I_{\mathrm{Na}}$ suggesting a modulatory effect of PKA on human $\mathrm{Na}_{\mathrm{v}} 1.5$ [139]. The same study demonstrated that this modulatory effect of PKA is conferred by the DI-DII intracellular linker of $\mathrm{Na}_{\mathrm{v}} 1.5$. In this regard, it has been reported that the rat $\mathrm{Na}_{\mathrm{v}} 1.5$ protein sequence harbors two distinct sites for PKA phosphorylation that were mapped to serine positions S526 (525 in human) and S529 (528 in human) [100,140-142]. These sites are localized in the cytosolic loop interconnecting DI and DII of $\mathrm{Na}_{\mathrm{v}} 1.5$, where the three putative RXR-type (R479KR481, R533RR535, and R659QR661) ER retention motifs have been localized too $[104,137,143]$. Zhou et al. have previously demonstrated that PKA activation promotes trafficking of channels to the plasma membrane [143]. In the same context, Scott et al. have shown that a PKA-PKC mediated phosphorylation of NMDA receptor masks its ER retention motifs leading thus to its release from the ER and exportation to the cell membrane [144]. Taken together, these findings suggest a similar mechanism where the phosphorylation of $\mathrm{Na}_{\mathrm{v}} 1.5$ at $\mathrm{S} 525$ and S528 by PKA leads to changes in the $\mathrm{Na}_{\mathrm{V}} 1.5$ conformation that masks the ER retention signals and eases the trafficking of the channel to the cell membrane [142,145]. This is consistent with the idea that proper folding of $\mathrm{Na}_{\mathrm{v}} 1.5$ unmasks its ER retention motifs and facilitates its forward trafficking to the Golgi apparatus [106].

In an antagonistic way to PKA, $\mathrm{Na}_{\mathrm{v}} 1.5$ is downregulated by protein kinase $\mathrm{C}(\mathrm{PKC})$ mediated phosphorylation which leads to a reduced channel density at the cell surface and $I_{\mathrm{Na}}$ decay [146]. Although ten different PKC isoforms have been identified in human ventricular myocytes and in different animal species [147], isoform-specific activation/inhibition studies suggested $\varepsilon$ PKC isoform as the key player in the PKC-mediated regulation of 
$\mathrm{Na}_{\mathrm{v}} 1.5$ and $I_{\mathrm{Na}}[148,149]$. Nonetheless, $\mathrm{PKC} \delta$-mediated $\mathrm{Na}_{\mathrm{v}} 1.5 / I_{\mathrm{Na}}$ downregulation either directly through phosphorylation at $\mathrm{S} 1503$ or indirectly through elevated mitoROS production has been reported [150]. In addition, a minor role of $\alpha \mathrm{PKC}$ reducing $I_{N a}$ through angiotensin II has also been described [151]. As a direct mechanism, the PKC (particularly $\varepsilon P K C$ ) effect on $\mathrm{Na}_{\mathrm{v}} 1.5$ and $I_{\mathrm{Na}}$ has been partially attributed to the phosphorylation of a conserved serine S1503 of the DIII-DIV cytosolic linker of $\mathrm{Na}_{\mathrm{v}} 1.5$ [152,153]. However, intracellular metabolic changes have been described as a mediator of PKC activation and PKC-mediated phosphorylation of $\mathrm{Na}_{\mathrm{v}} 1.5$ [150]. In this regard, high intracellular levels of NADH have been described as triggers of PKC, thus leading to overproduction of mitochondrial reactive oxygen species (mitoROS) and $I_{N a}$ decay [154-156]. This effect has been demonstrated to be mediated by glycerol 3-phosphate dehydrogenase 1 (GPD1L) [157] and could be reversed by NAD ${ }^{+}$-mediated PKA activation [154,158-160]. Interestingly, Fouda et al. have demonstrated that PKA and PKC phosphorylation pathways could be activated by Cannabidiol and Estradiol and that this activation could rescue the high glucose-induced changes in $\mathrm{Na}_{\mathrm{v}} 1.5$ properties [161,162].

Importantly, not far from the PKA phosphorylation sites in $\mathrm{Na}_{\mathrm{v}} 1.5$ DI-DII linker, there is a $\mathrm{Ca}^{2+}$ /Calmodulin-dependent Protein Kinase II (CaMKII) phosphorylation site as well, which was mapped to S516 [163]. This CaMKII phosphorylation site is not the only one in $\mathrm{Na}_{\mathrm{v}} 1.5$ since Ashpole et al. have identified four extra potential sites; all of them are localized in DI-DII linker, suggesting linker I as a hotspot for $\mathrm{Na}_{\mathrm{v}} 1.5$ phosphorylation [163]. However, a recent study by Herren et al. identified 23 sites along $\mathrm{Na}_{\mathrm{v}} 1.5$ intracellular regions that could be phosphorylated by CaMKII in human $\mathrm{Na}_{\mathrm{v}} 1.5$ [164]. More recently, Burel et al. identified two further CaMKII phosphorylation sites localized in the C-terminal region of $\mathrm{Na}_{\mathrm{v}} 1.5$ [165]. Several studies have shown that $\mathrm{Na}_{\mathrm{v}} 1.5$ is regulated by CaMKII and that activation of this kinase increases the so-called pathogenic late cardiac sodium current $I_{\mathrm{NaL}}$ [166]. Interestingly, El Refaey et al. demonstrated that $I_{\mathrm{NaL}}$ could also be regulated by B56 $\alpha$, the key regulatory subunit of the PP (protein phosphatase) 2A holoenzyme [167]. This phosphatase is targeted by ankyrin- $\mathrm{G}$ to the $\mathrm{Na}_{\mathrm{v}} 1.5-\mathrm{CaMKII}-\beta \mathrm{IV}$ spectrin axis at the ID where it is thought to dephosphorylate $\mathrm{Na}_{\mathrm{v}} 1.5$ at S571 in the DI-DII linker via B56 $\alpha$ balancing, thus the CaMKII-dependent phosphorylation of the cardiac sodium channel. According to a study by Deschênes et al., inhibition of CaMKII slowed $\mathrm{Na}_{\mathrm{v}} 1.5$ channel current decay, produced a depolarizing shift in fast inactivation, and slowed entry into inactivated states [168].

$\mathrm{Na}_{\mathrm{v}} 1.5$ is also phosphorylated by Tyrosine kinases. In this regard, phosphorylation of $\mathrm{Na}_{\mathrm{v}} 1.5$ by the Src family Tyrosine kinase Fyn has been first reported by Ahern and co-workers, who have demonstrated that this kinase acts by increasing the rates of recovery from fast-inactivated states, thus impairing the steady-state inactivation of $\mathrm{Na}_{\mathrm{v}} 1.5$ [169]. Fyn kinase acts most likely on Tyr1495 of $\mathrm{Na}_{\mathrm{v}} 1.5$ not far from the Ile-Phe-Met (IFM) motif of DIII-DIV linker that is known to modulate the rapid inactivation process of the channel [5]. In the heart, Fyn tyrosine kinases are reported to co-localize with $\mathrm{Na}_{\mathrm{v}} 1.5$ channels at adherens junctions, where they modulate electrical coupling and propagation of action potential $[170,171]$. Iqbal et al. found that the major $\mathrm{Na}_{\mathrm{v}} 1.5$ splice variants Q1077 and delQ1077 are differentially phosphorylated by Fyn kinase, which results in coordinated steady-state rapid inactivation kinetics for smooth electrical activity of the heart [172]. The same researchers suggested a multistep mechanism by which Fyn kinases bind and modulate $\mathrm{Na}_{\mathrm{v}}$ 1.5. This mechanism starts by the association of Fyn kinase to prolinerich regions in the DI-DII linker and C-terminal region of $\mathrm{Na}_{\mathrm{v}} 1.5$, which activates the phosphorylation of neighboring tyrosine residues in the N-terminal region ( $\mathrm{Y} 68, \mathrm{Y} 87$, and Y112), DIII-DIV linker (Y1494, Y1495), and C-terminal region (Y1811, Y1889) [169,172,173]. Particularly, Y1494 and Y1495 of the DIII-IV linker have been demonstrated to play an essential role in the anchoring of $\mathrm{Ca}^{+} /$Calmodulin to the $\mathrm{Na}_{\mathrm{v}} 1.5$ inactivation gate, and thus Fyn-mediated phosphorylation of the two Tyrosine residues has been suggested to reduce or abolish calmodulin binding and to impair the interaction of the side chain with the inactivation gate receptor [174]. 
Additionally, $\mathrm{Na}_{\mathrm{v}} 1.5$ has been reported to be dephosphorylated by the protein tyrosine phosphatase 1 (PTPH1), which interacts with the $\mathrm{Na}_{\mathrm{v}} 1.5 \mathrm{PDZ}$ domain binding site at the C-terminal region [101]. PTPH1-mediated dephosphorylation of $\mathrm{Na}_{\mathrm{v}} 1.5$ modulates its gating by shifting the steady-state inactivation towards hyperpolarized potentials [175].

Arginine Methylation

Beltran-Alvarez and co-workers evidenced for the first time that $\mathrm{Na}_{\mathrm{v}} 1.5$ is posttranslationally modified by arginine methylation at three residues (R513, R526, and R680) within the $\mathrm{Na}_{\mathrm{v}}$ 1.5 DI-DII linker [176]. This modification is catalyzed by arginine methyltransferases (PRMT) PRMT-3 and PMRT-5 and leads to an increased expression of $\mathrm{Na}_{\mathrm{V}} 1.5$ in cell surface [177]. Studying the PTMs of $\mathrm{Na}_{\mathrm{v}} 1.5$ in end-stage heart failure patients, the same team demonstrated that methylation of R526 is the major quality control step of any $\mathrm{Na}_{\mathrm{v}} 1.5$ arginine or lysine residue [178].

\section{N-Terminal and Lysine Acetylation}

Another PTM during the $\mathrm{Na}_{\mathrm{v}} 1.5$ life cycle is the acetylation process. Two types of acetylation have been reported so far: reversible and irreversible. The first type is mediated by histone acetyltransferases (HATs) which exert $\mathrm{N}$-terminal acetylation of a $\mathrm{Na}_{\mathrm{v}} 1.5$ lysine residue leading to enhanced trafficking of $\mathrm{Na}_{\mathrm{v}} 1.5$ and therefore to an increased $I_{\mathrm{Na}}$ current [179], whereas the second type of acetylation is mediated by N-terminal acetyltransferases (NATs), where a $\mathrm{Na}_{\mathrm{v}} 1.5$ alanine residue is acetylated and has been reported as a $\mathrm{Na}_{\mathrm{v}} 1.5$ degradation signal [177]. Interestingly, native $\mathrm{Na}_{\mathrm{v}} 1.5$ channels purified from end-stage heart failure patients were reported to lack the initiation of methionine and be acetylated at the resulting initial alanine residue [178]. Recently, Vikram et al. showed that $\mathrm{Na}_{\mathrm{v}} 1.5$ undergoes reversible lysine acetylation. For instance, sirtuin 1 deacetylase (Sirt1), an $\mathrm{NAD}^{+}$-dependent lysine deacetylase, has been demonstrated to regulate $\mathrm{Na}_{\mathrm{v}} 1.5$ channels by deacetylating lysine residue 1479 (K1479) in the DIII-DIV linker, which promotes $\mathrm{Na}_{\mathrm{v}} 1.5$ cell surface expression and increases $I_{\mathrm{Na}}$ [180]. Interestingly, the murine model of cardiac Sirt1 deficiency presents fatal cardiac conduction defects as a result of K1479 hyperacetylation, which decreases $\mathrm{Na}_{\mathrm{v}} 1.5$ cell surface expression and reduces $I_{\mathrm{Na}}$. These arrhythmogenic substrates are similar to those characterizing human $\mathrm{Na}_{\mathrm{v}} 1.5$ loss-offunction cardiac arrhythmias suggesting that $\mathrm{Na}_{\mathrm{v}} 1.5$ Sirt1-mediated deacetylation is crucial for the proper function of the cardiac sodium channel. It is noteworthy that the authors of this study raised an interesting point regarding the role of the functional interaction and interplay between different PTMs fine-tune regulating the $\mathrm{Na}_{\mathrm{v}} 1.5$ channel expression and function. In this regard, it has been suggested that $\mathrm{Na}_{\mathrm{v}} 1.5$ is regulated by Sirt1-mediated interaction between lysine acetylation and the ubiquitination in one hand and $\mathrm{NAD}^{+}$dependent interplay between PKC-mediated phosphorylation and Sirt1-mediated deacetylation in another hand [180].

\section{SUMOylation}

Although more than 25 years have passed since the discovery of SUMOylation, a posttranslational modification conjugating a small ubiquitin-like modifier (SUMO) molecule to a lysine residue in the substrate protein [181], very scarce information are currently available about the regulation of $\mathrm{Na}_{\mathrm{v}} 1.5$ by SUMOylation. For instance, only one study, that of Plant et al., has reported that one of the mechanisms underlying $I_{N a L}$ elevation in response to acute cardiac hypoxia is the quick SUMOylation of $\mathrm{Na}_{\mathrm{v}} 1.5$ channels at the cell surface [182]. Particularly, SUMOylation of K442 residue has been reported to contribute to the pathological increasing of $\mathrm{I}_{\mathrm{NaL}}$ and action potential prolongation through activation of $\mathrm{Na}_{\mathrm{v}} 1.5$ channels when they should normally be inactivated.

\section{S-Nitrosylation}

S-nitrosylation, a PTM consisting of the covalent binding of a nitrogen monoxide (NO) moiety to the thiol side chain of cysteine in the target protein, has recently gained 
progressive attention as a crucial quality control step that is required for the proper function of a given protein [183]. In the cardiomyocytes, NO is produced by neuronal nitric oxide synthase (nNOS) [184]. nNOS mediated S-nitrosylation of $\mathrm{Na}_{\mathrm{V}} 1.5$ has been demonstrated to maintain $I_{\mathrm{NaL}}$ [185]. Interestingly, $\mathrm{nNOS}$ has been shown to interact with $\mathrm{Na}_{\mathrm{v}} 1.5$ via its regulating protein $\alpha 1$-syntrophin, which acts as a scaffolding protein bringing together $\mathrm{Na}_{\mathrm{v}} 1.5$ with nNOS and plasma membrane Ca-ATPase (PMCA4b) (an inhibitor of nNOS activity) [186]. Therefore, LQTS-associated $\alpha 1$-syntrophin mutation has been demonstrated to break the SNTA1- PMCA4b association neutralizing, thus the nNOS inhibition and increasing $\mathrm{Na}_{\mathrm{v}} 1.5 \mathrm{~S}$-nitrosylation, which in turn increase $I_{\mathrm{NaL}}$ currents [186]. A similar effect has been observed with a decreased caveolin 3(Cav3) expression, which has been shown to enhance S-nitrosylation of $\mathrm{Na}_{\mathrm{v}} 1.5$ through increasing the nNOS activity, which increased $I_{N a L}$ in cardiomyocytes [187]. However, a very recent study by Wang and co-workers suggested an indirect mechanism by which S-nitrosylation modulates the cardiac sodium channel expression and function. For instance, $\mathrm{NO}$ has been demonstrated to down-regulate SCN5A expression and $\mathrm{Na}_{\mathrm{v}} 1.5$ function through S-nitrosylation of regulatory transcription factor FOXO1 [188]. These findings increase our current understanding of the role of redox and free radicals in the regulation of $\mathrm{Na}_{\mathrm{v}} 1.5$ function (see [100] for further review).

\section{Lipoxidation}

Lipoxidation refers to the establishment of covalent adducts between reactive products of lipid peroxidation and macromolecules such as proteins, phospholipids, and DNA [189]. Recently, lipoxidation gained interest as a post-translational modification of the cardiac sodium channel that gives further evidence on the regulation of $\mathrm{Na}_{\mathrm{v}} 1.5$ by oxidative stress [190]. Nonetheless, little information is currently available about the mechanism of $\mathrm{Na}_{\mathrm{v}} 1.5$ regulation by lipoxidation. In this respect, in vitro data by Nakajima and co-worker provided the first evidence that $\mathrm{Na}_{\mathrm{v}} 1.5$ is post-translationally modified by lipoxidation during oxidant injury and that sodium channel dysfunction evoked by lipid peroxidation could be prevented by scavenging Isoketals (IsoKs), which are the most reactive products of lipoxidation [191].

\section{Methionine Oxidation}

A previous study by Quiñonez et al. demonstrated that skeletal $\mathrm{Na}_{\mathrm{v}} 1.4$ fast inactivation could be impaired by oxidizing at least two methionine residues in the channel [192]. These findings have been supported in cardiac $\mathrm{Na}_{\mathrm{v}} 1.5$ as well, where oxidative modification of the methionine within the IFM motif has been shown to lead to a drastic loss of $\mathrm{Na}_{\mathrm{v}} 1.5$ inactivation [193]. Interestingly, $\mathrm{Na}_{\mathrm{V}} 1.5$ channels and $I_{\mathrm{Na}}$ currents have been reported to be indirectly modulated by CaMKII, the activation of which depends on the oxidation of its own methionine residues [194].

\section{Palmitoylation}

Palmitoylation (also called S-acylation) is the PTM of protein cysteines with saturated fatty acids that modify protein hydrophobicity and thereby influence their function [195]. Palmitoylation has been reported to regulate ion channel's function, most likely through controlling their trafficking and cell membrane expression $[99,196]$. An early study by Schmidt et al. showed that $\mathrm{Na}_{\mathrm{v}} 1.5$ is subject to palmitoylation [99]. However, palmitoylation has been demonstrated to slightly influence cell surface expression of $\mathrm{Na}_{\mathrm{v}} 1.5$ and rather significantly impact channel availability by regulating the voltage dependence of steady-state inactivation in both HEK293 cells and cardiomyocytes [197]. Additionally, cysteine residues predicted to be palmitoylated in $\mathrm{Na}_{\mathrm{v}} 1.5$ are mapped to the DII-DIII linker of the channel by prediction algorithms [197].

\subsubsection{Regulation of the ER-to-Golgi Trafficking}

Well folded and assembled proteins are supposed to cross the ER-Golgi space in vesicle budding guided by cytoskeletal proteins [198]. Studying the subcellular distribution 
of the cardiac sodium channel $\mathrm{Na}_{\mathrm{v}} 1.5$ in HEK293 Cells and canine cardiac myocytes, Zimmer et al. noticed an accumulation of the intracellular channels within the ER and a lower channel density in the Golgi apparatus. Thereby, they proposed that ER plays the role of an intracellular reservoir where sodium channels are transiently stored [199]. As discussed previously, stimulation of PKA likely results in the activation of the ER-toGolgi trafficking, which in turn leads to a rapid increase of the channel density in the cell membrane [104]. However, the whole mechanisms underlying the ER exit of $\mathrm{Na}_{\mathrm{v}} 1.5$ to the Golgi is not yet fully deciphered, and current advances in this topic show that not only the PKA-mediated phosphorylation of the $\mathrm{Na}_{\mathrm{v}} 1.5 \mathrm{ER}$ retention sites is what facilitates its ER-Golgi exportation. That is, several proteins and enzymes have been reported to bind to $\mathrm{Na}_{\mathrm{v}} 1.5$ once retained to the ER and enhance its release. In this context, Wu et al. have identified the Ran-guanine nucleotide release factor (RANGRF or MOG1) as a cofactor of $\mathrm{Na}_{\mathrm{v}} 1.5$, which by binding to its intracellular loop DII-DIII facilitates its cell surface expression [200]. Using the DII-DIII linker of $\mathrm{Na}_{\mathrm{v}} 1.5$, in yeast two-hybrid analyses, the team demonstrated that MOG1 is crucial for the optimal expression of $\mathrm{Na}_{\mathrm{v}} 1.5$ and promotes its ER export and intracellular trafficking to the plasma membrane [200]. These findings are consistent with Chakrabarti et al. study, which showed that silencing of MOG1 expression by small interfering RNAs caused retention of $\mathrm{Na}_{\mathrm{v}} 1.5$ in the ER, reduced $\mathrm{Na}_{\mathrm{v}} 1.5$ plasma membrane expression, and disrupted the $\mathrm{Na}_{\mathrm{v}} 1.5$ targeting to the cell surface, in particular, to the caveolin-enriched microdomains (caveolae) [201]. A subsequent mutational study performed by $\mathrm{Yu}$ et al. further revealed that mutations in the amino acids E83, D148, R150, and S151 of MOG1 disrupt its interaction with $\mathrm{Na}_{\mathrm{v}} 1.5$ and significantly reduce the cardiac sodium channel trafficking to the cell surface, suggesting that these amino acids are important for the MOG1- $\mathrm{Na}_{\mathrm{v}} 1.5$ binding and interaction [9]. The same team found that MOG1-mediated trafficking and function of $\mathrm{Na}_{\mathrm{v}} 1.5$ requires the interaction of MOG1 with two small GTPases SAR1A and SAR1B and that the knockdown of both enzymes abolishes the function of MOG1 [202]. Furthermore, it has been demonstrated that activation of SAR1 leads to the recruitment and internalization of $\mathrm{Na}_{\mathrm{v}} 1.5$ cargo into the coated transition vesicle COPII-coated vesicles that will ensure its ER-to-Golgi trafficking [202]. The $\mathrm{Na}_{\mathrm{v}} 1.5$ ER export is also controlled by Dynamitin as demonstrated by Chatin et al., who have proved, using a yeast two-hybrid system, that Dynamitin (C-terminal domain), interacted with the $\mathrm{Na}_{\mathrm{v}} 1.5 \mathrm{DI}-\mathrm{DII}$ linker between amino acids 417 and 444 and that this interaction is crucial for the $\mathrm{Na}_{\mathrm{v}} 1.5$ cell-surface density probably through controlling the ER-to-Golgi trafficking [203].

\subsubsection{Regulation of $\mathrm{Na}_{\mathrm{v}} 1.5$ Maturation and Golgi Export}

Once in the Golgi, $\mathrm{N}$-glycosylated $\mathrm{Na}_{\mathrm{v}} 1.5$ undergoes additional mannose trimming and terminal glycosylation where acetyl-glucosamine, oligosaccharides, and finally sialic acid residues are sequentially added as the protein crosses the distinct Golgi cisternae. It has been demonstrated that glycosylation regulates voltage-gated sodium channels (including $\mathrm{Na}_{\mathrm{v}} 1.5$ ) gating, inactivation, and recovery process during cardiac AP by interfering with the electric field near the gating sensors [204-208]. Hence, it has been suggested that extracellular sialic acid residues, which are negatively charged at physiological $\mathrm{pH}$, modulate the sensitivity of the $\mathrm{Na}_{\mathrm{v}} 1.5$ voltage sensor domains to the transmembrane electrical potential fluctuation [209]. Particularly, sialic acid residues localized to DI S5-S6 have been demonstrated to regulate the sialic acid-dependent gating of $\mathrm{Na}_{\mathrm{v}} 1.5$ [125].

Mature $\mathrm{Na}_{\mathrm{v}} 1.5$ (fully glycosylated) are exported from the Golgi apparatus, which acts as a major secretory sorting hub that targets newly synthesized proteins to their final subcellular destinations [210]. Although the current knowledge on the exact mechanisms regulating the $\mathrm{Na}_{\mathrm{v}} 1.5$ export from the Golgi and trafficking to the cell membrane is still limited, a recent study by Ponce-Balbuena and co-workers reported that $\mathrm{Na}_{\mathrm{v}} 1.5$ Golgi export is driven by a trafficking signal localized in its terminal $\mathrm{COOH}$ region. This signal corresponds to a binding site of the adaptor protein complex 1 (AP1) mapped to $\mathrm{Na}_{\mathrm{v}} 1.5^{\prime} \mathrm{s}$ Y1810 residue. AP1-marked $\mathrm{Na}_{\mathrm{v}} 1.5$ will be then incorporated into clathrin-coated vesicles that 
will migrate to the cell membrane where the channel will be anchored [211]. The same team showed that the $\mathrm{Na}_{\mathrm{v}} 1.5$ cross the Golgi-cell membrane space by a common anterograde trafficking pathway as Kir2.1. These findings support previous studies demonstrating that both ion channels form a channelosome that shares common trafficking, targeting, anchoring, recycling, and degradation pathways [212,213].

\subsubsection{Regulation of the $\mathrm{Na}_{\mathrm{v}} 1.5$ Targeting to the Cell Membrane}

Over the last few years, it became widely accepted that not all the $\mathrm{Na}_{\mathrm{v}} 1.5$ proteins synthesized in one cardiomyocyte undergo the same regulatory steps till reaching their final localization in the cell membrane [214]. After years of debate and controversial studies about the subcellular distribution of the cardiac sodium channel, the new cellular imaging techniques excluded the idea of an exclusive expression of $\mathrm{Na}_{\mathrm{v}} 1.5$ at the ID [171,215] and gave way to a more conceivable model that suggests a multi-pool aggregation of $\mathrm{Na}_{\mathrm{v}} 1.5$ along with the cellular membrane compartments including the LM and the Ttubules [216-218]. Being in one membrane domain or the other put the $\mathrm{Na}_{\mathrm{v}} 1.5$ in distinct microenvironments composed of different interacting proteins that regulate its gating function and biophysical properties. Above all these interacting proteins, beta subunits are without doubt the ones that most gained interest in this field over the last few decades as their presence and function are dependent on the presence of the pore-forming $\alpha$-subunit (Figures 2 and 3).

Regulation of $\mathrm{Na}_{\mathrm{v}} 1.5$ by $\beta$-Subunits

The $\beta$ subunit family consists of four different proteins $\beta 1-4$ encoded by four genes, $S C N 1 B-S C N 4 B$, respectively, with $\beta 1$ alternatively spliced into two isoforms, $\beta 1 \mathrm{~A}$ and $\beta 1 B$ [219]. As mentioned earlier in this review, the $\beta$-subunits, most likely $\beta 1$-subunits, assemble with $\mathrm{Na}_{\mathrm{v}} 1.5$ at the endoplasmic reticulum and influence its maturation and trafficking to the plasma membrane $[127,220]$. Alpha-beta subunits assembly is either covalent ( $\beta 2$ or $\beta 4$ ) or non-covalent ( $\beta 1$ or $\beta 3$ ) [221]. Particularly, $\beta 4-\mathrm{Na}_{\mathrm{v}} 1.5$ covalent association is ensured by an extracellular cysteine-cysteine single disulfide bond [222,223], while $\beta 2$ does not form a disulfide linkage at this position with $\mathrm{Na}_{\mathrm{v}} 1.5$ as recently specified [5], whereas $\beta 1$ and $\beta 3$ non-covalently interact with $\mathrm{Na}_{\mathrm{v}} 1.5$ through the channels DIV and DIII voltage gating domain respectively [224].

Despite the structural similarities between $\beta 2 / \beta 4$ on one hand and $\beta 1 / \beta 3$ on the other hand, their expression differs from one cellular sub-domain to another. Inside the cardiomyocyte, $\beta 3$ are expressed at the T-tubules and $\beta 4$ at the ID, while $\beta 1$ and $\beta 2$ are found at both locations $[215,225,226]$. Zimmer et al. have suggested that, unlike $\beta 2, \beta 1$ associates to $\mathrm{Na}_{\mathrm{v}} 1.5$ early at the ER, and both $\alpha$ and $\beta 1$ subunits are trafficked together to their final destination at the cell membrane [227]. Subsequent studies revealed that $\beta 1-$ subunits enhance the $\alpha$-subunits dimerization and promote the dominant-negative effect of trafficking defective mutants [228]. $\beta 2$ has been reported to promote surface localization of $\mathrm{Na}_{\mathrm{v}} 1.5$ [229]. Importantly, $\beta 3$ subunits have been demonstrated to bind to $\mathrm{Na}_{\mathrm{v}} 1.5$ in multiple sites and promote the formation of $\alpha$ subunit oligomers, including trimers [230]. However, $\beta 4$ has been reported as a modulator of $\mathrm{Na}_{\mathrm{v}} 1.5$ kinetic and gating properties by increasing $I_{\mathrm{Na}}$ [231]. Taken together, these findings are consistent with the idea that the distinct sodium channel $\beta$ subunits provide support for the pore-forming subunit, facilitate the trafficking of the mature channel to the different membrane domains, and modulate the gating function of $\mathrm{Na}_{\mathrm{v}} 1.5$ by increasing the $I_{\mathrm{Na}}$ [232-236]. More details regarding the regulation of $\mathrm{Na}_{\mathrm{v}} 1.5$ by $\beta$ subunits in the context of sodium channelopathies are discussed in Section 4 of this review. 

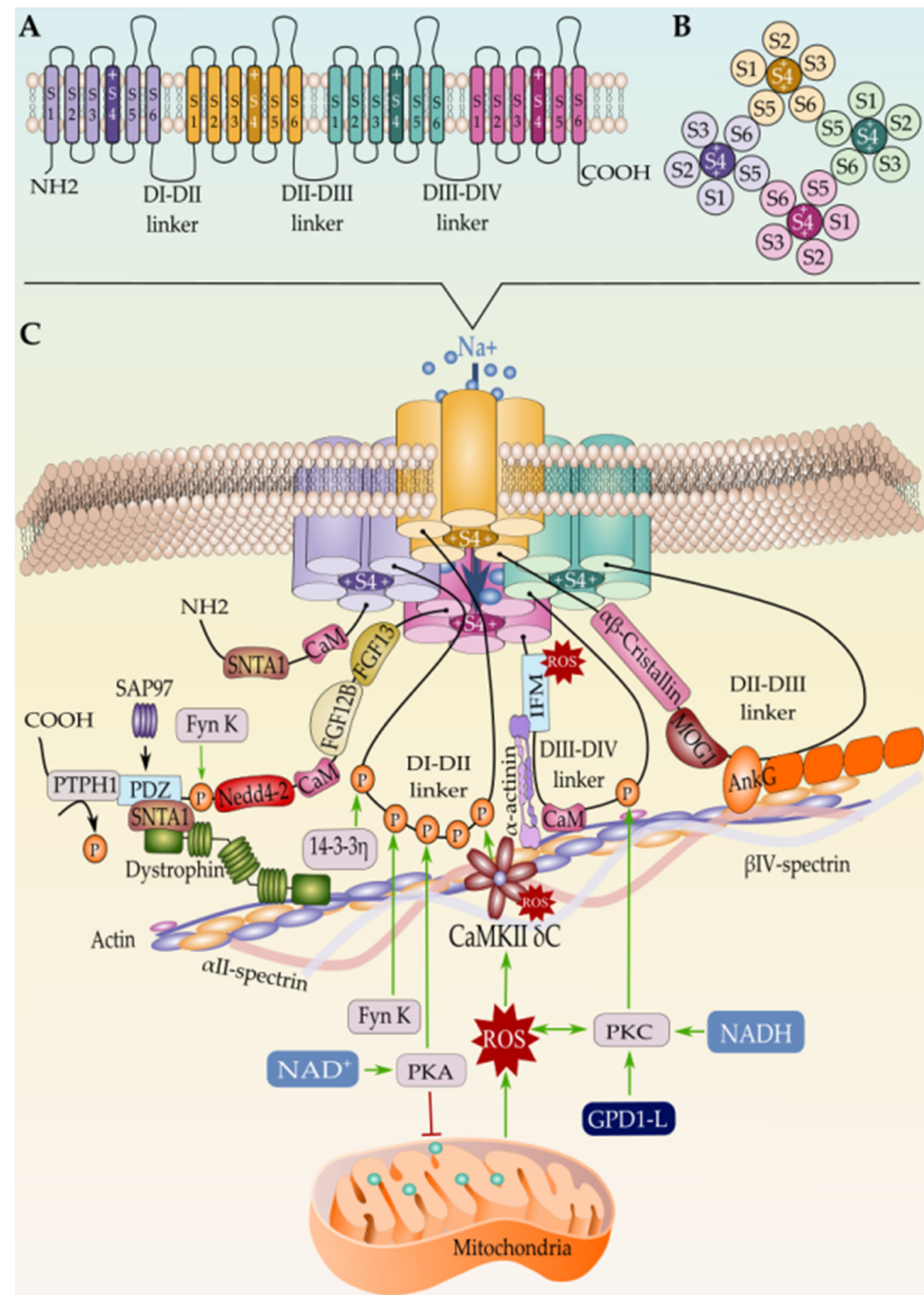

Figure 3. (A) Schematic representation of the $\mathrm{Na}_{\mathrm{v}} 1.5$ secondary structure, (B) the intracellular view of the channel, and $(\mathbf{C})$ the tertiary structure along with the interacting proteins. Only proteins with known binding sites in $\mathrm{Na}_{\mathrm{v}} 1.5$ are represented here. Mechanism of $\mathrm{Na}_{\mathrm{v}} 1.5$ regulation by the mitochondrial reactive oxygen species ROS is represented as well.

The $\mathrm{Na}_{\mathrm{v}} 1.5$ and the Intercalated Disc Interactome

As suggested by the Delmar research team, several evidence point to the fact that the ID is not a hub of proteins playing independent functions within the cardiomyocyte, but rather a network of molecules interacting together in order to fulfill a specific function (AP propagation, cell-to-cell coupling, cardiac excitability, etc.) that cannot be accomplished 
if this "interactome" is impaired [237]. As a component of the ID proteins, $\mathrm{Na}_{\mathrm{v}} 1.5$ has been demonstrated to be in the heart of this interactome by physically and functionally associating to several proteins belonging to this macromolecular complex.

In this context, it is currently well known that $\mathrm{Na}_{\mathrm{v}} 1.5$ targeted to the ID are "tagged" with synapse-associated protein 97 (SAP97), a scaffolding MAGUK ((membrane-associated guanylate kinase) protein that is abundantly expressed in human and rat ventricular myocardium [238]. SAP97 has been introduced as the determinant of the $\mathrm{Na}_{\mathrm{v}} 1.5$ ID pool as it plays an important role in targeting $\mathrm{Na}_{\mathrm{v}} 1.5$ along with Kir2.1 to this cell membrane domain $[238,239]$. Both channels were structurally evidenced to co-assemble to SAP97 by their C-terminal domains $[238,240]$. For $\mathrm{Na}_{\mathrm{v}} 1.5$, it is assumed that the last three aminoacids (serine-isoleucine-valine or SIV motif) of the C-terminal region form a PDZ (postsynaptic density protein (PSD95), Drosophila disc large tumor suppressor (Dlg1), and zonula occludens-1 protein (zo-1) domain binding motif) that interacts with the syntrophindystrophin complex at the cardiomyocyte LM and PDZ domains of SAP97 at the ID [218]. In the absence of the PDZ-domain-binding motif of $\mathrm{Na}_{\mathrm{v}} 1.5$ or SAP97, $\mathrm{Na}_{\mathrm{v}} 1.5$ expression at the cell surface decreased, thus leading to a reduction in the cardiac $I_{\mathrm{Na}}$ in vitro [241]. However, a subsequent study by the same team demonstrated that in vivo ablation of SAP97 did not change $\mathrm{Na}_{\mathrm{v}} 1.5$ localization and function, but it did decrease the cardiac potassium currents [242]. The authors of these studies justified this discrepancy by the fact that SAP97 silencing in vitro is induced in adult cardiomyocytes while in vivo, it is a constitutive ablation present early in development, which may impact protein expression and interactions.

In addition, the $\mathrm{Na}_{\mathrm{v}} 1.5-\mathrm{SAP} 97-\mathrm{Kir} 2.1$ complex has been demonstrated to reach the ID through the microtubule highway $[133,238,239,243]$. Although the exact mechanism by which $\mathrm{Na}_{\mathrm{v}} 1.5$ is targeted to the ID is not yet fully discovered, part of it is already elucidated. A few years ago, Agullo-Pascual et al. proved for the first time that the microtubule plus-end tracking protein "end-binding 1" (EB1) is captured to the IDs by connexin 43 (cx43), which facilitates the cargo delivery, including $\mathrm{Na}_{\mathrm{v}} 1.5$ [244]. These findings are consistent with Marchal and co-workers' recent study in which they have further proved that EB1 modulates $\mathrm{Na}_{\mathrm{v}} 1.5$ trafficking to the IDs and that loss of EB1 function leads to reduced $I_{\mathrm{Na}}$ and conduction slowing [245]. Moreover, EB1 has been previously demonstrated to bind directly to CLASP2 (cytoplasmic linker associated protein 2) and form a complex at the microtubule plus-end, promoting thus microtubule polymerization and stabilization [246]. Interestingly, inhibiting the GSK3 $\beta$ (glycogen synthase kinase $3 \beta)$-mediated phosphorylation of CLASP2 enhanced the EB1-CLASP2 interaction, which in turn led to an increased $\mathrm{Na}_{\mathrm{v}} 1.5$ delivery at the ID of cardiomyocytes and an increased $I_{\mathrm{Na}}$ [245]. Furthermore, Rhett et al. have shown that in addition to its known localization at the gap junction where it interacts with zonula occludens-1 (ZO-1) [247,248], Cx43 also co-localizes with ZO-1 in the zone surrounding the gap junction, conventionally termed as perinexus and that $\mathrm{Cx} 43$ but not $\mathrm{ZO}-1$ interact with $\mathrm{Na}_{\mathrm{v}} 1.5$ at this zone in physiological conditions [249]. In vivo and in vitro assays show that $\mathrm{Na}_{\mathrm{v}} 1.5$ expression and function are reduced as a result of $\mathrm{C} \times 43$ expression/function decrease, thus giving more evidence that Cx43 is required for a proper $\mathrm{Na}_{\mathrm{v}} 1.5$ function at the ID [250].

Importantly, $\mathrm{Na}_{\mathrm{v}} 1.5$ and $\mathrm{Cx} 43$ interaction at the perinexus is thought to be mediated by scaffolding proteins SAP97 and Ankyrin G (AnkG) as their interaction has been reported [241,251]. In the cardiovascular system, ankyrins are critical components of ion channels and transporter signaling complexes, and their dysfunction has been linked with abnormal ion channel and transporter membrane organization and fatal human arrhythmias [252]. Although both ankyrin-B (AnkB, encoded by ANK2) and ankyrin-G (ANK3) have been found to be expressed in the myocardium, only ankyrin-G has been shown to interact with $\mathrm{Na}_{\mathrm{v}} 1.5$ [253]. Specifically, AnkG is necessary for normal expression of $\mathrm{Na}_{\mathrm{v}} 1.5$ and acts as a coordinating signaling center, functionally coupling $\mathrm{Na}_{\mathrm{v}} 1.5$ gating with upstream kinase and phosphatase enzymes and downstream cytoskeletal proteins $[110,254]$. AnkG is primarily expressed at the ID membrane and T tubules, where it co-localizes with 
$\mathrm{Na}_{\mathrm{v}} 1.5$ [142]. In vitro, it has been demonstrated that AnkG binds to $\mathrm{Na}_{\mathrm{v}} 1.5$ and that AnkG downregulation impaired the subcellular localization of $\mathrm{Na}_{\mathrm{v}} 1.5$ and reduced the $I_{\mathrm{Na}}$ current amplitude $[255,256]$. In vivo, Makara and his collaborators have demonstrated that AnkG plays an indispensable role in directing $\mathrm{Na}_{\mathrm{v}} 1.5$ and its regulatory protein CaMKII to the ID [254,257]. Mutational studies have further confirmed that disrupting the binding of AnkG to $\mathrm{Na}_{\mathrm{v}} 1.5$ impairs AnkG dependent targeting of the $\mathrm{Na}^{+}$channel to the ID leading thus to a reduction in $I_{\mathrm{Na}}$ density and cardiac arrhythmias [253,254,258]. A recent study performed by Yang et al. has demonstrated that AnkG, but not AnkB, are expressed at the IDs and that masking $\mathrm{Na}_{\mathrm{v}} 1.5$ binding sites in $\mathrm{AnkG}$ using competitive peptides caused a decrease in sodium channel current $\left(I_{N a}\right)$ and targeting defects of the $\mathrm{Na}^{+}$channels to the ID, but not to LM [213]. However, a more recent study by Cavus and collaborators specified that only canonical AnkG isoforms have this regulatory effect on $\mathrm{Na}_{\mathrm{v}} 1.5$ and that noncanonical (giant) AnkG isoforms mediated electrical dysfunction is independent of $\mathrm{Na}_{\mathrm{v}} 1.5$ [259].

Furthermore, AnkG is thought to mediate the interaction between Cx43 and PKP2, thus connecting desmosomal proteins with the molecular complex that captures the microtubule plus-end at the ID, thus allowing for delivery of $\mathrm{Na}_{\mathrm{v}} 1.5[244,256,260]$. This is consistent with the fact that loss of desmosomal integrity impacts cardiac conduction and leads to cardiac arrhythmias [260-262]. Accordingly, loss of Plakophilin-2 (PKP2), a crucial component of the cardiac desmosome, has been demonstrated to decrease $I_{\mathrm{Na}}$ in cardiac myocytes [263]. Similarly, loss of PKP2 expression in HL1 cells and in induced pluripotent stem cell-derived cardiomyocytes (iPSC-CMs) from a patient with PKP2 deficiency reduced $I_{N a}$ amplitude [261,264]. Likewise, Rizzo et al. have demonstrated that desmoglein-2 (Dsg2), another desmosome protein, physically interacts with $\mathrm{Na}_{\mathrm{v}} 1.5$ at the ID of mouse cardiomyocytes in vivo [265]. They showed that mice models over-expressing a desmoglein2 mutation present a wider intercellular space at the level of the ID, longer ventricular activation time, lower conduction velocity, lower upstroke velocity, and lower $I_{\mathrm{Na}}$ amplitude compared to wild type. Although no evidence of direct interaction between Desmoplakin (DSP) and $\mathrm{Na}_{\mathrm{v}} 1.5$ has been reported, RNAi-based Desmoplakin silencing in vitro resulted in a reduction in $\mathrm{Na}_{\mathrm{v}} 1.5$ expression at the ID of cardiomyocytes, an abnormal sub-cellular distribution of $\mathrm{C} \times 43$ and $\mathrm{Na}_{\mathrm{v}} 1.5, I_{\mathrm{Na}}$ decay, and slowed conduction velocity suggesting that DSP regulates $\mathrm{Na}_{\mathrm{v}} 1.5$ [266].

Similarly, AnkG is established as an adaptor protein that organizes, transports, and anchors $\mathrm{Na}_{\mathrm{v}} 1.5$ to the actin/spectrin cytoskeleton [267-269]. In fact, the AnkyrinG-Na 1.5 complex is believed to connect with the actin/ $\alpha$-spectrin cytoskeleton through CaMKII$\beta_{\mathrm{IV}}$-spectrin interaction where the latter acts as a CaMKII-anchoring protein and thereby orchestrating the whole macromolecular complex; however, no evidence of direct interaction between $\mathrm{Na}_{\mathrm{v}} 1.5$ and $\beta_{\mathrm{IV}}$-spectrin has been found yet [255]. On the other hand, $\beta_{\mathrm{IV}}$-spectrin is assumed to control the CaMKII-dependent regulation of $\mathrm{Na}_{\mathrm{v}} 1.5$ at the ID, and loss of $\beta_{\mathrm{IV}}$-spectrin/CaMKII interaction precludes CaMKII-dependent phosphorylation of $\mathrm{Na}_{\mathrm{v}} 1.5$ at Serine 571 in the DI-DII linker and abolishes the stress-induced activation of the pathogenic $I_{N a, L}[270,271]$.

Remme's team [272] has recently demonstrated that ID $\mathrm{Na}_{\mathrm{v}} 1.5$ physically interacts with coxsackie and adenovirus receptor (CAR), a single-pass transmembrane cell adhesion molecule (CAM) [273]. Furthermore, they have demonstrated that CAR haploinsufficiency decreased $I_{\mathrm{Na}}$ amplitude at the ID, which in turn reduced sodium channel availability at this cell membrane compartment. $\mathrm{Na}_{\mathrm{v}} 1.5-\mathrm{CAR}$ interaction is only beginning to be understood, and thus, mechanisms underlying this interaction are still to be studied.

Our current understanding regarding the $\mathrm{Na}_{\mathrm{v}} 1.5$ auto-regulation is still limited. Over the last decades, several controversial studies emerged regarding the sodium channel $\alpha$ - $\alpha$-subunits interaction and dimerization. However, Clatot and co-workers settled this controversy by demonstrating for the first time that trafficking-defective $\mathrm{Na}_{\mathrm{v}} 1.5$ exerts a dominant-negative effect on non-defective ones through $\alpha$ - $\alpha$-subunits physical interaction at their $\mathrm{N}$-terminal regions, precluding thus their cell surface expression [274]. Building 
on these findings, the team further evidenced that cardiac sodium channel $\alpha$-subunits assemble as dimers with coupled gating and that this dimerization is mediated through an interaction site found within the DI-II linker of $\mathrm{Na}_{\mathrm{v}} 1.5$, between amino acids 493 and 517 [275]. Curiously, earlier studies have shown that 14-3-3 protein, a member of highly conserved cytosolic acidic proteins, physically interacts with the DI-II linker of $\mathrm{Na}_{\mathrm{V}} 1.5$ (between amino acid 417 and 467) at the ID and that this interaction facilitates the dimerization of cardiac sodium channels [276]. Strikingly, Clatot et al. identified a second 14-3-3 protein- $\mathrm{Na}_{\mathrm{v}} 1.5$ interaction site between amino acid 517-555 and demonstrated that co-operative gating behavior but not dimerization of $\alpha$-subunits is dependent on 14-3-3$\mathrm{Na}_{\mathrm{v}} 1.5$ interaction [275].

\section{$\mathrm{Na}_{\mathrm{v}} 1.5$ and the Lateral Membrane's Interactome}

$\mathrm{Na}_{\mathrm{v}} 1.5$ targeting to the LM has been demonstrated to be mediated by the syntrophindystrophin complex $[3,241]$; however, a sub-pool of $\mathrm{Na}_{\mathrm{v}} 1.5$ at the $\mathrm{LM}$, which is independent of syntrophin, has been recently characterized as well [277]. Dystrophin is known to indirectly mediate $\mathrm{Na}_{\mathrm{v}} 1.5$ expression at the LM through binding to Syntrophin adapter protein which physically associates to the PDZ domain-binding motif at the C-terminal region of $\mathrm{Na}_{\mathrm{v}} 1.5[3,241,278-280]$. Interestingly, Matamoros et al. demonstrated that $\alpha 1-$ syntrophin also interacts with the N-terminal region of $\mathrm{Na}_{\mathrm{v}} 1.5$ through an "internal" PDZ-like binding domain localized at this region which acts as "chaperone-like" domain that increases $\mathrm{Na}_{\mathrm{v}} 1.5$ density at the $\mathrm{LM}$ and $I_{N a}$ [281]. The same mechanism has been validated for Kir2.1 and Kir2.2 that were demonstrated to reciprocally interact with $\mathrm{Na}_{\mathrm{v}} 1.5$ channels and modulate each other's trafficking and expression [281,282].

Interestingly, $\mathrm{Na}_{\mathrm{v}} 1.5$ has been demonstrated to interact with CASK (calcium/calmodulindependent serine kinase), a member of the MAGUK protein family [283]. In several ways, CASK is considered an unconventional $\mathrm{Na}_{\mathrm{v}} 1.5$ regulator since it is the only MAGUK protein that is lateral membrane-specific and also the only $\mathrm{Na}_{\mathrm{V}} 1.5$ interacting protein that exerts a repressive effect on the functional expression of $\mathrm{Na}_{\mathrm{v}} 1.5$, most likely by preventing its early trafficking to the LM. In this regard, CASK has been demonstrated to decrease $I_{N a}$ when the former is over-expressed and to increase $I_{\mathrm{Na}}$ when CASK is inhibited in vivo and in vitro [283].

In addition, $\mathrm{Na}_{\mathrm{v}} 1.5$ has been evidenced to interact with members of the Z-line scaffolding protein complex, such as $\alpha$-actinin- 2 and telethonin. While $\alpha$-actinin- 2 is currently known to physically interact with $\mathrm{Na}_{\mathrm{v}} 1.5$ through the channel DIII-DIV linker [284], the telethonin interaction site on $\mathrm{Na}_{\mathrm{v}} 1.5$ has not yet been identified [101]. $\alpha$-actinin-2 is thought to positively regulate $\mathrm{Na}_{\mathrm{v}} 1.5$ by increasing its cell surface expression, most likely through promoting its anchoring to the contact zones between T-tubules and Z-lines and connecting the channel to the actin cytoskeleton network [284]. However, scarce information is available regarding the mechanism of $\mathrm{Na}_{\mathrm{v}} 1.5$ regulation by telethonin, although physical interaction between TCAP and $\mathrm{Na}_{\mathrm{v}} 1.5$ was evidenced by co-immunoprecipitation methods and mutations in the telethonin coding gene (TCAP) has been found to alter the channel-gating properties of $\mathrm{Na}_{\mathrm{v}} 1.5$ in patients with abnormal gut motility and Brugada syndrome $[285,286]$.

Moreover, the role of fibroblast growth factor homologous factors (FHFs), a subset of the fibroblast growth factor (FGF) family [287], has been well elucidated modulating the neuron voltage-gated sodium channels [288]. However, their role in controlling cardiac sodium channel function is still poorly understood and subject to debate. In this respect, fibroblast growth factor homologous factor 1B (FHF1B), also known as FGF12B, has been reported to regulate the biophysical properties and kinetics of $\mathrm{Na}_{\mathrm{V}} 1.5$ through its physical interaction (amino acids 1773-1832) with the $\mathrm{Na}_{\mathrm{v}} 1.5 \mathrm{C}$ terminal region [289]. Both in vitro data show that FHF1B interacts with $\mathrm{Na}_{\mathrm{v}} 1.5$, and this interaction results in hyperpolarizing shift in steady-state inactivation of this channel [289]. However, the opposite effect has also been reported where a depolarizing shift in the V1/2 of steady-state inactivation has been attributed to the FHF1B-Na 1.5 interaction [290]. Furthermore, FGF13 (FHF2), 
which is the major FHFs in adult mouse hearts, has been identified as a $\mathrm{Na}_{\mathrm{v}} 1.5$ interacting protein [290]. In the cardiomyocyte, FHF2 co-localizes with distinct $\mathrm{Na}_{\mathrm{v}} 1.5$ pools, i.e., the LM and ID suggesting an important role for FHF2 modulating $\mathrm{Na}_{\mathrm{v}} 1.5$ cell surface expression and function [291]. Like FGF12B, FGF13 physically binds to $\mathrm{Na}_{\mathrm{v}} 1.5$ through the channel's $\mathrm{C}$ terminus region. In vivo, FGF13 knockdown altered $\mathrm{Na}_{\mathrm{v}} 1.5$ function resulting in a decreased $I_{\mathrm{Na}}$ current density, reduced $\mathrm{Na}_{\mathrm{v}} 1.5$ channel availability, slowed $\mathrm{Na}_{\mathrm{v}} 1.5$, and reduced $I_{\mathrm{Na}}$ current recovery from inactivation [290]. This effect of FGF13 is isoformspecific [292]. FHFs have also been implicated in voltage-gated sodium channel trafficking control. In this context, FGF14 has been reported as a modulator of $\mathrm{Na}_{\mathrm{v}} 1.5$ current densities in neurons and in the heart by impairing their biophysical properties or by controlling channel trafficking and cell surface expression in vitro [293].

Furthermore, calmodulin $(\mathrm{CaM})$, a ubiquitous $\mathrm{Ca}_{2}{ }^{+}$-sensing protein, has been reported to interact with $\mathrm{Na}_{\mathrm{v}} 1.5 \mathrm{~N}$ - and C-terminal regions [294-297] and the DIII-IV linker [174,295]. This interaction has been demonstrated to enhance slow inactivation and modulate $\mathrm{Na}_{\mathrm{v}} 1.5$ gating [296], while disruption of CaM binding to $\mathrm{Na}_{\mathrm{v}} 1.5$ decreases channel activity and enhances the propensity for persistent $\mathrm{Na}^{+}$current, all resulting from a switch in the $\mathrm{Na}_{V}$ inactivation mechanism [297]. $\mathrm{Na}_{\mathrm{V}} 1.5-\mathrm{CaM}$ interaction has been further studied in a mutational context related to cardiac sodium channelopathies (See Section 4).

Finally, dipeptidyl peptidase-like protein-10 (DPP10), previously reported as a modulator of $\mathrm{K}_{\mathrm{v}} 4$.3-current kinetics [298], has recently emerged as a new regulator of $\mathrm{Na}_{\mathrm{v}} 1.5$ [299]. In vivo, DPP10 has been reported to modulate $\mathrm{Na}_{\mathrm{v}} 1.5$ current kinetics as well by altering voltage dependence of $\mathrm{Na}^{+}$current and upstroke velocity of the action potential [299].

\section{The Caveolar $\mathrm{Na}_{\mathrm{v}} 1.5$}

Cardiac sodium channels have also been localized to cardiomyocyte caveolae, which are specialized subsarcolemmal membrane compartments enriched in lipids and play a crucial role in vesicular trafficking and protein targeting to the cell surface [300,301]. Caveolar $\mathrm{Na}_{\mathrm{v}} 1.5$ is exposed to a very rich macromolecular complex encompassing fatty acids, ion channels (pacemaker channels, potassium channels, calcium channels, etc.), and signaling complexes (G-protein-coupled receptors, protein kinases, etc.). This microenvironment has been reported to regulate $\mathrm{Na}_{\mathrm{V}} 1.5$ function and membrane expression in a multilayers fashion [301].

The first layer is related to the biochemical properties of caveolae itself as a specialized lipid raft rich in fatty acids. In this regard, previous reports demonstrated that $\mathrm{Na}_{\mathrm{v}} 1.5$ is blocked by polyunsaturated fatty acids (PUFAs), suggesting that interaction of $\mathrm{Na}_{\mathrm{v}} 1.5$ with the caveolar lipids that also include PUFAs might have the same effect $[302,303]$. Nonetheless, the mechanism by which caveolar lipid rafts regulate $\mathrm{Na}_{\mathrm{v}} 1.5$ is not yet fully understood.

The second layer of caveolar $\mathrm{Na}_{\mathrm{v}} 1.5$ regulation is mediated by caveolins which are the major proteins of caveolae [301]. This mechanism was first reported by the Shibata group, which demonstrated that in addition to the indirect $\beta$-adrenergic regulation of $\mathrm{Na}_{\mathrm{v}} 1.5$, which is PKA-dependent, stimulation of the $\beta$-adrenergic pathway in the presence of a PKA inhibitor, activates G-protein $(\mathrm{Gs} \alpha)$ cascade, which in turn leads to a rapid increase of $I_{N a}$ [300]. A subsequent study by the same group suggested that caveolar $\mathrm{Na}_{\mathrm{V}} 1.5$ channels are stored at caveolae invaginations and that PKA-independent Gs $\alpha$-dependant stimulation of the $\beta$-adrenergic pathway leads to the opening of caveolae, the exposition of $\mathrm{Na}_{\mathrm{v}} 1.5$ channels to the extracellular environment, which in turn increase $I_{\mathrm{Na}}$ [304]. This mechanism has been completely neutralized by anti-caveolin 3 antibodies dialyzed into the myocytes suggesting that caveolar $\mathrm{Na}_{\mathrm{v}} 1.5$ function is dependent on the Gs $\alpha$-Caveolin 3 (Cav3) interaction [304]. Although $\mathrm{Na}_{\mathrm{v}} 1.5$ has been confirmed to interact with caveolin 3 in rodent and human cardiomyocytes [300,305], it is not yet clear if this interaction is direct or indirect. Several reports suggested that Cav3 modulates $\mathrm{Na}_{\mathrm{V}} 1.5$ function indirectly through inhibiting the nNOS, which is a part of the $\mathrm{Na}_{\mathrm{v}} 1.5-\mathrm{SNTA1}$-PMCA4b macromolecular complex [305,306]. As mentioned earlier in this review, a decay in Cav3 expression has 
been demonstrated to activate S-nitrosylation of $\mathrm{Na}_{\mathrm{v}} 1.5$ through increasing the local $\mathrm{NO}$ production, which increased $I_{N a, L}$ in cardiomyocytes [187].

\subsubsection{Regulation of $\mathrm{Na}_{\mathrm{v}} 1.5$ Degradation}

Maintaining the balance between protein synthesis and degradation is crucial for the fine-tune regulation of $\mathrm{Na}_{\mathrm{v}} 1.5$ levels [307]. In fact, it is currently well established that internalization and degradation of $\mathrm{Na}_{\mathrm{v}} 1.5$ are regulated either by ubiquitination, covalent attachment of ubiquitin moieties [308], or autophagy [309]. The first mechanism is mediated by the interaction of C-terminus PY motifs of $\mathrm{Na}_{\mathrm{v}} 1.5$ with the fourth tryptophan-rich domain (WW) of E3 ubiquitin ligase NEDD4-2, which leads to the labeling of $\mathrm{Na}_{\mathrm{V}} 1.5$ by ubiquitin residues that will be later recognized by the degradation machine $[100,310,311]$. Interestingly, yeast two-hybrid data demonstrated that the interaction between $\mathrm{Na}_{\mathrm{v}} 1.5 / \alpha \beta$ Cristallin from one hand and $\alpha \beta$-Cristallin/Nedd4-2 from another hand reduced internalization of cell surface $\mathrm{Na}_{\mathrm{v}} 1.5$ and ubiquitination of $\mathrm{Na}_{\mathrm{v}} 1.5$ [312]. Similarly, serum and glucocorticoid inducible kinase (SGK) has been reported to regulate $\mathrm{Na}_{\mathrm{v}} 1.5$ degradation by phosphorylating and inhibiting Nedd4-2 [313], whereas UBC9, a SUMO-conjugating enzyme, has been shown to promote $\mathrm{Na}_{\mathrm{v}} 1.5$ ubiquitination [314]. A very recent study by Liu et al. demonstrated that $\mathrm{Na}_{\mathrm{v}} 1.5$ ubiquitination would be downregulated by the association of FAT10, a small ubiquitin-like modifier, to the C-terminal lysine residues of $\mathrm{Na}_{\mathrm{v}} 1.5$, thus decreasing the binding of $\mathrm{Na}_{\mathrm{v}} 1.5$ to the Nedd4-2 and preventing its degradation [315].

Nedd4-2 has been reported as a direct target of AMP-activated protein kinase (AMPK) in epithelial cells [316]. However, a recent report by Liu X et al. attributed a Nedd4-2 independent $\mathrm{Na}_{\mathrm{v}} 1.5$ degradation mechanism to AMPK [309]. AMPK, through phosphorylating $\mathrm{Na}_{\mathrm{V}} 1.5 \mathrm{~T} 101$ residue, facilitates the association of the channel to the autophagic adapter protein and microtubule-associated protein 1 light chain 3 (LC3) and exposes the complex to the autophagic degradation machinery [309].

\subsubsection{Effect of Gonadal Hormones on $\mathrm{Na}_{\mathrm{v}} 1.5$ Expression and Function}

The male predominance of some sodium channelopathies such as Brugada syndrome has been extensively studied over the last few years, thus questioning a possible link between sex hormones and $\mathrm{Na}_{\mathrm{v}} 1.5[317,318]$. However, comparing the expression levels of $\mathrm{Na}_{\mathrm{v}} 1.5$ between normal male and female human hearts showed no difference [319]. In addition, concentration-related block of $\mathrm{Na}_{\mathrm{v}} 1.5$ by estradiol showed that estradiol could not reduce the current of $\mathrm{Na}_{\mathrm{v}} 1.5$ [320], although a slight reduction in $I_{\mathrm{Na}}$ currents has been observed at a high concentration of estradiol in vitro [321]. Yang et al. have recently studied the expression levels and function of $\mathrm{Na}_{\mathrm{v}} 1.5$ in HEK293 cells co-expressing SCN5A (wildtype or BrS mutants R878C and R104W) and sex hormone receptors. They whereby showed that sex hormones have no effects on the expression level of SCN5A (either WT or mutant) and $I_{\mathrm{Na}}$ currents [322]. Similarly, gonadal hormones testosterone and estrogen showed no effect on fast $I_{N a}$ in a canine model [323]. However, a recent study by Hu et al. demonstrated that estrogen through its rapid signal receptor GPER ameliorated the damaging effects of stress in human induced pluripotent stem cell-derived cardiomyocytes (hiPSC-CMs) model mimicking $\beta$-adrenergic overstimulation [324]. Taken together, these findings demonstrate that our current knowledge on the regulation of $\mathrm{Na}_{\mathrm{v}} 1.5$ by sex hormones is still limited and that further studies in this regard are necessary.

\subsubsection{Effect of Temperature and $\mathrm{pH}$ on $\mathrm{Na}_{\mathrm{v}} 1.5$ Expression and Function}

Febrile states and acidosis are two environmental factors that have been extensively studied as non-genomic modulators of $\mathrm{Na}_{\mathrm{v}} 1.5$ function in health and disease. It is currently well known that $\mathrm{Na}_{\mathrm{v}} 1.5$ kinetic is temperature and $\mathrm{pH}$-sensitive [325]. In this context, mild hypothermia has been described as an antiarrhythmic factor that maintains myocardial conduction during prolonged ischemia by sustaining $\mathrm{Na}_{\mathrm{v}} 1.5$ and $\mathrm{Cx} 43$ function [326], whereas hyperthermia has been described as a proarrhythmic factor, especially in combination with SCN5A mutations as is the case in Brugada syndrome [327-330]. Two mechanisms 
have been suggested so far for the temperature-dependent regulation of $\mathrm{Na}_{\mathrm{v}} 1.5$. The first one is a direct mechanism by which temperature accelerates the inactivation of only the wild-type $\mathrm{Na}_{\mathrm{v}} 1.5$ channels in heterozygous patients, which results in the misbalance between depolarization and repolarization currents and thus may lead to fever-induced arrhythmias [40,331]. The second mechanism is indirect by which temperature modulates the function of $\mathrm{Na}_{\mathrm{v}} 1.5$ interacting proteins, which in turn modulate $\mathrm{Na}_{\mathrm{v}} 1.5$ function as is the case of FGF13 [332].

Similarly, fluctuation of the extracellular $\mathrm{pH}$ has been demonstrated to influence the $\mathrm{Na}_{\mathrm{v}} 1.5$ function. For instance, acidic extracellular $\mathrm{pH}$ has been shown to modify wildtype $\mathrm{Na}_{\mathrm{v}} 1.5$ kinetics by destabilizing both the fast inactivated and the slow inactivated states of $\mathrm{Na}_{\mathrm{v}} 1.5$ [333]. In addition, it has been reported that extracellular protons disrupt charge immobilization which leads to the destabilization of the $\mathrm{Na}_{\mathrm{v}} 1.5$ fast-inactivation through direct interaction with outer ring carboxylates of the $\mathrm{Na}_{\mathrm{v}} 1.5$ DIII or DIV [334]. Particularly, His- 880 and Cys-373 were identified as the key mediator of $\mathrm{Na}_{\mathrm{v}} 1.5$ sensitivity to $\mathrm{pH}$ fluctuation, where Cys-373 is responsible for isoform-specific proton modulation of use-dependent inactivation of $\mathrm{Na}_{\mathrm{v}} 1.5$ [335].

\section{Cardiac Sodium Channelopathies}

SCN5A dysfunction has been extensively reported in distinct cardiac channelopathies such as long QT syndrome, Brugada syndrome, atrial fibrillation, ventricular fibrillation, sick sinus syndrome, and sudden infant death syndrome, as well as in complex electrophysiological disorders that combine several of the previously mentioned channelopathies. In the next paragraphs, we provide an updated view of the mutational, genomic, and nongenomic contribution to SCN5A dysfunction on each of these channelopathies (Table 1).

\subsection{Long QT Syndrome}

Seminal studies by Wang et al. [336] determined a causative link between SCN5A mutations and long QT syndrome (LQT3). These authors also determined the biophysical and functional characteristics of the novel identified mutations that displayed non-inactivating $I_{N a}$ amounting to a few percent of the peak inward $I_{N a}$, as well as impairment on voltage dependence and rate of inactivation and the rate of recovery from inactivation [337]. Since these early studies, more than 80 different mutations have been identified in SCN5A associated with LQT, accounting for $5-10 \%$ of the cases (see for recent reviews [14,338-341]). Functional analyses of several of the identified LQT SCN5A variants displayed gain-offunction either by increasing the late phase of the $I_{\mathrm{Na}}$ or increasing the window current or both conditions simultaneously, yet our current understanding of the functional roles of most SCN5A mutations described remains elusive.

In addition to mutations on SCN5A associated with long QT syndrome, several $S C N 5 A / \mathrm{Na}_{\mathrm{v}} 1.5$ interacting proteins have also been associated in this context. Mutations in the sodium channel ancillary protein $S C N 1 B$ are associated with LQT, leading to increased $I_{N a L}$ [342], while mutations in $S C N 4 B$ have also been identified [231], yet its plausible implication in LQT is still disputed [343]. Besides these ancillary subunits, a large number of proteins have been reported to interact with $S C N 5 A / \mathrm{Na}_{\mathrm{v}} 1.5$, as recently reviewed by Abriel Hugues [101] and detailed in the previous subchapters of this manuscript. In this context, mutations in syntrophin (SNTA1) and caveolin (Cav3) are associated with long QT and disrupt sodium channel function, increasing the $I_{N a L}[186,187,344-347]$. On the other hand, mutations in BAG3, ankyrin B (ANKB), and $\alpha$-actinin (ACTN1) leads to LQT, but it remains unclear how such mutations affect the $I_{N a}[294,348,349]$, while calmodulin $(C a M)$ and telethonin (TCAP) have been implicated in $S C N 5 A / \mathrm{Na}_{\mathrm{v}} 1.5$ interaction and function $[163,285]$ yet to date no mutations have been reported in the context of LQT syndrome.

The genomic contribution to long QT syndrome in transcriptional regulators of SCN5A expression is still incipient since only variants on TBX5 have been reported but not in any of the other transcriptional modulators. Variants affecting transcriptional regulators influencing SCN5A expression have been recently linked to long QT syndrome. In particular, 
Markunas et al. [350] described a TBX5 variant that co-segregated with prolonged QT interval in a family with otherwise genotype-negative LQTS and demonstrated that such variant impaired the transactivation capacity of this transcription factor. Nieto-Marín et al. [351] reported two additional TBX5 variants that co-segregated with LQT and BrS patients and electrophysiologically impaired $I_{\mathrm{Na}}$ currents in vitro.

Several SCN5A mutations leading to splice donor variants have been associated with LQT [339,352-357]; however, to date, the functional relationship between the distinct $S C N 5 A$ isoforms and this syndrome remains to be elucidated. While our current understanding of distinct non-coding RNAs in cardiovascular pathology is increasingly emerging, no data are available regarding the functional contribution of microRNAs and/or lncRNAs to long QT syndrome physiopathology. Similarly, the contribution of post-transcriptional $S C N 5 A / \mathrm{Na}_{\mathrm{v}} 1.5$ regulation by phosphorylation, glycosylation, acetylation, and/or methylation to QT syndrome has not been reported, and the contribution of ubiquitination is currently controversial [358,359]. Importantly, acetylation in $K C N H 2$, i.e., another ion channel that, if mutated, contributes to long QT syndrome, has been reported [360], opening the possibility that $S C N 5 A / \mathrm{Na}_{\mathrm{v}} 1.5$ post-transcriptional regulation also contributes to LQT.

\subsection{Brugada Syndrome}

SCN5A mutations were associated for the first time to the right bundle branch and ST-elevation syndrome, i.e., Brugada syndrome by Chen et al. [25]. These authors identified a two-nucleotide insertion after the first four nucleotides of the splice donor sequence in intron 7, leading to impaired $S C N 5 A$ splicing. They also identified a deletion of a single nucleotide in the SCN5A gene that resulted in the elimination of two transmembrane domains and the C-terminal portion of the cardiac sodium channel. Since then, an increasing number of SCN5A mutations have been reported to be associated with Brugada syndrome. To date, more than a hundred mutations have been reported in BrS. Functional analyses of several of these SCN5A reported mutations to demonstrate in most cases, a loss-of-function is achieved, either by decreased $\mathrm{Na}_{\mathrm{v}} 1.5$ expression in the sarcolemma, because the channels are non-functional or because there is an impaired gating off the channel that results in decreased $I_{\mathrm{Na}}$ current. However, only a relatively limited number of $S C N 5 \mathrm{~A}$ mutations associated with BrS have been fully electrophysiologically characterized.

Importantly, single point mutations have also been associated with both long QT and BrS phenotypes [26,361], and several of these have been electrophysiologically characterized [24,362-365], yet the precise molecular mechanism of their dual action remains enigmatic.

As previously reported in the context of LQT, in addition to mutations on $S C N 5 A$, several $S C N 5 A / \mathrm{Na}_{\mathrm{v}} 1.5$ interacting proteins have also been associated with Brugada syndrome. Mutations in the sodium channel ancillary proteins SCN1B [232,356,359,366-370], $S C N 2 B$ [229], and SCN3B [356] are associated with Brugada syndrome, leading in several cases to decrease $I_{\mathrm{Na}}$ current [366] and/or cellular trafficking defects $[229,356]$. Besides the role of the sodium channel ancillary subunits, additional $S C N 5 A / \mathrm{Na}_{\mathrm{v}} 1.5$ interacting proteins have been reported in BrS. Mutations in Plakophilin (PKP2) $[260,371]$ MOG1 [9,201,372-375], FGF13 [376], syntrophin (SNTA1) [377], NEDD4 [378,379], Tmem168 [379] and telethonin [285,286] are identified in BrS patients and their implication to sodium channel function has been reported. Distinct $\mathrm{Na}_{\mathrm{v}} 1.5$ interacting protein mutants lead to $I_{\mathrm{Na}}$ deficit $[261,286,375,377]$ while others influence $\mathrm{Na}_{\mathrm{v}}$ trafficking and thus subcellular localization [201,379].

On the other hand, mutations in desmoglein and SAP97 have been described in BrS patients [380,381], but their influence on $S C N 5 A / \mathrm{Na}_{\mathrm{v}} 1.5$ remains to be elucidated, while calmodulin, CamKII, and GPD1L modulation of $S C N 5 A / \mathrm{Na}_{\mathrm{v}} 1.5$ is well-established $[157,163,382,383]$, but to date, no mutation in these genes have been reported in the context of Brugada syndrome.

At the transcriptional level, Nieto-Marín [351] identified TBX5 variants associated with BrS and LQT, as previously mentioned. Furthermore, additional evidence of the tran- 
scriptional modulation of SCN5A expression in Brugada syndrome, including GATA4 [384] and IRX3 [385] variants, have been reported. Transcriptional contributions by mutations in the SCN5A promoter are also linked to Brugada syndrome [384], causing decreased $S C N 5 A / \mathrm{Na}_{\mathrm{v}} 1.5$ and $I_{\mathrm{Na}}$, thus loss-of-function. Importantly, they have also been associated with distinct arrhythmogenic diseases [24,386]. More recently, [387] reported that a common SCN5A polymorphism, i.e., H558R, modulates the SCN5A promoter methylation and thus the clinical phenotype of Brugada syndrome patients. However, it remains unclear which are the molecular mechanisms underlying such association.

The importance of non-coding RNAs in the context of Brugada syndrome has been recently explored using an integrative omics approach [388]. These authors identified several microRNAs that are distinctly upregulated in BrS, such as miR-92a-3p and miR-320b, or down-regulated such as miR-425-5p and established their plausible links as molecular determinants of Brugada syndrome, yet functional evidence is missing. More recently, Matsumura et al. [93] described $S C N 5 A$ coding variants that lack genotype-phenotype concordance, and additionally, SCN5A 3'UTR variants were identified that impaired microRNA binding sites but similarly failed to properly segregate with BrS phenotype [93], suggesting that a combination of multiple genetic factors, rather than a single variant is the cause of BrS onset [93]. Thus, to date, the plausible role of ncRNAs in BrS remains almost unexplored.

Our current understanding of the mechanistic links between $S C N 5 A / \mathrm{Na}_{\mathrm{v}} 1.5$ posttranscriptional modifications and the onset of Brugada syndrome is scarce. Aiba et al. [389] described that R526H and S528A SCN5A mutations, identified in a BrS family, impaired $\mathrm{Na}_{\mathrm{v}} 1.5$ phosphorylation, leading to reduced peak current densities, yet steady-state activation, inactivation, and recovery for inactivation were not modified. Besides this study, no additional links for glycosylation, acetylation, and/or methylation have been reported in the context of BrS.

\subsection{Atrial Fibrillation}

Atrial fibrillation has also been associated with mutations in SCN5A. Ellinor et al. reported missense mutation in a 45-year-old male proband and his affected father among a series of 57 probands with a familial history of isolated or 'lone' atrial fibrillation [384]. More recently, Darbar et al. [390] identified eight heterozygous variants in ten probands that were not found in age-, sex-, and ethnicity-matched controls. In addition, rare nonsynonymous coding region variants previously reported were also demonstrating that in their study, nearly $6 \%$ of $\mathrm{AF}$ probands carried heterozygous mutations or rare SCN5A variants. Thus, the causal contribution of SCN5A to familial AF is limited.

Curiously, an extensive array of SCN5A mutations have been associated with atrial fibrillation and other electrophysiological disorders such as BrS [391], cardiac conduction defects [392], LQT [393], and even a spectrum of atrial flutter, conduction diseases, and BrS [394].

Mutations in all sodium channel ancillary subunits have been reported in atrial fibrillation patients [395-398], while only mutations in Mog1 [375,399], ankyrin [400,401], alpha-actinin [402], and caveolin [403] have been associated with atrial fibrillation among those other $S C N 5 A / \mathrm{Na}_{\mathrm{v}} 1.5$ interacting proteins. Curiously, no evidence of their functional impact on $S C N 5 A / \mathrm{Na}_{\mathrm{v}} 1.5$ function is reported to date.

\subsection{Ventricular Fibrillation}

Mutations in SCN5A have been associated with ventricular fibrillation [404-406] and idiopathic ventricular fibrillation [407-409]. However, a large array of SCN5A mutations linked to ventricular fibrillation are reported in the context of additional cardiac impairments, such as Brugada syndrome [410-413], atrial fibrillation [414], acute myocardial infarction [415-417], sudden cardiac death [418,419], or Graves' disease [420]. Surprisingly, while abundant information is available about the genetic determinants of ventricular 
fibrillation, scarce information is available about the molecular mechanisms leading to ventricular fibrillation.

Genetic screening of sodium channel ancillary subunits has revealed only mutation in SCN3B associated with ventricular fibrillation [421]. Although no direct evidence of mutations in desmosomal proteins such as desmoglein or plakoglobin has been reported in ventricular fibrillation, there is compiling evidence that such mutations in the context of arrhythmogenic right ventricular cardiomyopathy (ARVD) predispose to an early onset of ventricular fibrillation [422-425]. In addition to those $S C N 5 A / \mathrm{Na}_{\mathrm{v}} 1.5$ interacting proteins, mutations in calmodulin [426,427] and alpha-actinin [428] have also been reported in ventricular fibrillation patients, yet their plausible implications deregulating $S C N 5 A / \mathrm{Na}_{\mathrm{v}} 1.5$ is not reported to date.

Within the currently described transcriptional regulators of SCN5A expression, only mutations in IRX3 have been associated with ventricular fibrillation [65]. Interestingly, those IRX3 mutations impaired SCN5A expression in in vitro experimental assays, yet the causal contribution to ventricular fibrillation remains unclear. On the other hand, no evidence has been reported so far on $S C N 5 A / \mathrm{Na}_{\mathrm{v}} 1.5$ post-transcriptional modifications in the context of ventricular fibrillation.

\subsection{Sick Sinus Syndrome}

Ample evidence has been reported on SCN5A mutations leading to sick sinus syndrome $[29,429-436]$ alone or in combination with other electrophysiological disorders such as atrial fibrillation [437] and Brugada syndrome with conduction diseases [30]. However, no mutations in sodium channels ancillary subunits or $S C N 5 A / \mathrm{Na}_{\mathrm{v}} 1.5$ interacting proteins have been reported. Similarly, no link between SCN5A transcriptional and posttranscriptional regulators and sick sinus syndrome is reported to date.

\subsection{Sudden Infant Death Syndrome}

Mutations in SCN5A are also causative of sudden infant death syndrome [438-444] as well as in channel ancillary subunits [445-448]. It is assumed that, as in the case of Brugada syndrome, an $S C N 5 A / \mathrm{Na}_{\mathrm{v}} 1.5$ loss-of-function underlies sudden infant death. In this context, Tan et al. [446] described $S C N 3 B$ and $S C N B 4$ mutations that decreased peak $I_{N a}$ current but increased $I_{N a L}$, whereas Neubauer et al. [412] and Denti et al. [447] identified a novel $S C N 1 B$ mutations that decreased $I_{N a}$ density, providing thus plausible electrophysiological mechanisms underlying sudden infant death syndrome. Importantly SCN5A mutations in SIDS have also been identified in conjunction with other electrophysiological disorders, such as Brugada syndrome [356].

In addition to those mutations, several $S C N 5 A / N a_{v} 1.5$ interacting proteins have also been associated with sudden infant cardiac syndromes, such as calmodulin [383,449], syntrophin $[186,346,450]$, and caveolin $[187,451]$. Cheng et al. reported that syntrophin mutation leads to increased peak $I_{\mathrm{Na}}$ current and overlap between activation and inactivation curves increasing thus the window current [186]. Similar findings on the increased peak $I_{\mathrm{Na}}$ current were also reported by Wu et al. [346] and Cheng et al. [450], a phenotype that was rescued by another calmodulin variant identified in SIDS. Caveolin mutations seem to distinctly contribute to sodium regulation, either by suppressing the $I_{N a L}$ by inhibiting nNOS-dependent S-nitrosylation of SCN5A [187] or by the persistence of the $I_{N a L}$ [451].

On the other hand, no association between $S C N 5 A$ transcriptional and post-transcriptional modulators and sudden infant death syndrome has been reported to date.

\subsection{Other Channelopathies}

SCN5A mutations also play a pivotal role in complex electrophysiological disorders that present a combination of alterations, particularly on conduction disorders associated with sick sinus syndrome, atrial fibrillation and ventricular tachycardia [435]; LQT and BrS [452]; atrial fibrillation, BrS, and sudden cardiac death [394]; BrS [453]; BrS and AF [454]; or atrial arrhythmias [392]. Similarly, increasing evidence is also reported in cases of sudden 
cardiac death, alone [455] or in combination with LQT and dilated cardiomyopathy [452], ventricular fibrillation and BrS [456], or atrial fibrillation [433]. Our current understanding of the molecular mechanisms providing such diversity of phenotypic manifestations is still limited. It is important nonetheless to highlight that mutations in $S C N 5 A / \mathrm{Na}_{\mathrm{v}} 1.5$ interacting proteins $[9,201,401]$ and/or transcriptional regulators [457] have also been recently reported to be associated with these complex electrophysiological disorders.

Table 1. Summary of the $\mathrm{Na}_{\mathrm{v}} 1.5$-interacting protein-coding genes involved in cardiac sodium channelopathies.

\begin{tabular}{|c|c|c|c|}
\hline Altered Gene/Alteration & Effect on $I_{N a}$ Current & Mode of Action & References \\
\hline \multicolumn{4}{|c|}{ Long QT syndrome } \\
\hline SCN5A & $\begin{array}{c}\text { Increased } I_{\mathrm{NaL}} \\
\text { increased window current }\end{array}$ & NA & {$[14,336,338-341]$} \\
\hline SCN1B & Increased $I_{N a L}$ & Ancillary subunit & [342] \\
\hline$S C N 4 B$ & Undetermined & Ancillary subunit & {$[231,343]$} \\
\hline SNTA1 & Increased $I_{N a L}$ & $\begin{array}{l}\text { Activation of nNOS-SCN5A } \\
\text { macromolecular complex }\end{array}$ & {$[186,187,344-347]$} \\
\hline Cav3 & Increased $I_{\mathrm{NaL}}$ & $\begin{array}{l}\text { nNOS-dependent S-nitrosylation of } \\
\text { SCN5A }\end{array}$ & [187] \\
\hline$B A G 3$ & Undetermined & Undetermined & [348] \\
\hline$A N K B$ & Undetermined & Undetermined & [258] \\
\hline ACTN1 & Undetermined & Undetermined & [349] \\
\hline TBX5 & Increased $I_{\mathrm{NaL}}$ & Transactivation impairment & {$[350,351]$} \\
\hline \multicolumn{4}{|c|}{ Brugada syndrome } \\
\hline SCN5A & Decreased $I_{N a}$ & NA & {$[24-26,361-365]$} \\
\hline SCN1B & Decreased $I_{N a}$ & $\begin{array}{l}\text { Ancillary subunit; cellular trafficking } \\
\text { defects }\end{array}$ & {$[232,356,359,366-370]$} \\
\hline$S C N 2 B$ & Decreased $I_{N a}$ & $\begin{array}{c}\text { Ancillary subunit; cellular trafficking } \\
\text { defects }\end{array}$ & [229] \\
\hline$S C N 3 B$ & Decreased $I_{N a}$ & $\begin{array}{c}\text { Ancillary subunit; cellular trafficking } \\
\text { defects }\end{array}$ & [356] \\
\hline PKP2 & Decreased $I_{\mathrm{Na}}$ & $I_{N a}$ deficit & {$[260,371]$} \\
\hline MOG1 & Decreased $I_{\mathrm{Na}}$ & $I_{\mathrm{Na}}$ deficit; subcellular trafficking & {$[9,201,372-375]$} \\
\hline FGF13 & Decreased $I_{N a}$ & Enhanced $\mathrm{Na}_{\mathrm{v}} 1.5$ inactivation & [376] \\
\hline SNTA1 & Decreased $I_{\mathrm{Na}}$ & Defective $\mathrm{Na}_{\mathrm{V}} 1.5$ protein interaction & [377] \\
\hline TMEM168 & Decreased $I_{\mathrm{Na}}$ & Reduced $\mathrm{Na}_{\mathrm{v}} 1-5$ expression & {$[378,379]$} \\
\hline TCAP & Decreased $I_{N a}$ & Defective $\mathrm{Na}_{\mathrm{v}} 1.5$ protein interaction & {$[285,286]$} \\
\hline SAP97 & Undetermined & Undetermined & {$[380,381]$} \\
\hline TBX5 & Undetermined & Transactivation impairment & [351] \\
\hline GATA4 & Undetermined & Undetermined & [384] \\
\hline$I R X 3$ & Undetermined & Undetermined & [385] \\
\hline $\begin{array}{l}\text { SCN5A promoter } \\
\text { methylation }\end{array}$ & Undetermined & $\begin{array}{l}\text { Decreased SCN5A promoter } \\
\text { methylation }\end{array}$ & [387] \\
\hline SCN5A promoter mutations & Undetermined & Transactivation impairment & [384] \\
\hline$N a_{v} 1.5$ phosphorylation & Reduced peak $I_{\mathrm{Na}}$ density & Impaired PKA stimulation & [389] \\
\hline \multicolumn{4}{|c|}{ Atrial fibrillation } \\
\hline SCN5A & Undetermined & NA & {$[384,390]$} \\
\hline SCN1B & Reduced $I_{N a}$ & $\begin{array}{c}\text { Ancillary subunit; altered channel } \\
\text { gating }\end{array}$ & [395] \\
\hline$S C N 2 B$ & Reduced $I_{N a}$ & $\begin{array}{c}\text { Ancillary subunit; altered channel } \\
\text { gating }\end{array}$ & [395] \\
\hline$S C N 3 B$ & Undetermined & Ancillary subunit & [398] \\
\hline$S C N 4 B$ & Undetermined & Ancillary subunit & {$[396,397]$} \\
\hline MOG1 & Reduced $I_{N a}$ & Undetermined & {$[375,399]$} \\
\hline$A N K$ & Undetermined & Undetermined & {$[400,401]$} \\
\hline ACTN1 & Undetermined & Undetermined & [402] \\
\hline Cav3 & Undetermined & Undetermined & [403] \\
\hline
\end{tabular}


Table 1. Cont.

\begin{tabular}{|c|c|c|c|}
\hline Altered Gene/Alteration & Effect on $I_{N a}$ Current & Mode of Action & References \\
\hline \multicolumn{4}{|c|}{ Ventricular fibrillation } \\
\hline SCN5A & Reduced $I_{N a}$ & $N A$ & [404-406] \\
\hline$S C N 3 B$ & Reduced peak $I_{N a}$ & $\begin{array}{l}\text { Ancillary subunit; impaired } \\
\text { trafficking }\end{array}$ & [421] \\
\hline CaM & Undetermined & Undetermined & {$[426,427]$} \\
\hline ACTN1 & Undetermined & Undetermined & [428] \\
\hline IRX3 & Undetermined & Impaired transactivation & [65] \\
\hline \multicolumn{4}{|c|}{ Sick sinus syndrome } \\
\hline SCN5A & Reduced $I_{N a}$ & NA & {$[29,429-436]$} \\
\hline \multicolumn{4}{|c|}{ Sudden infant death syndrome } \\
\hline SCN5A & Increased $I_{N a L}$ & Impaired $\mathrm{Na}_{\mathrm{v}} 1.5$ inactivation & [438-444] \\
\hline$S C N 1 B$ & Decreased $I_{N a}$ density & Ancillary subunit & [447] \\
\hline$S C N 3 B$ & $\begin{array}{l}\text { Decreased } I_{N a}, \\
\text { Increased } I_{N a L}\end{array}$ & Ancillary subunit & {$[446,448]$} \\
\hline$S C N 4 B$ & $\begin{array}{l}\text { Decreased } I_{N a} \\
\text { Increased } I_{N a I}\end{array}$ & Ancillary subunit & {$[446]$} \\
\hline CaM & Undetermined & Undetermined & {$[383,449]$} \\
\hline SNTA1 & $\begin{array}{l}\text { Increased peak } I_{\mathrm{Na}} \text { and } \\
\text { window current }\end{array}$ & Undetermined & {$[186,346,450]$} \\
\hline Cav3 & Suppression of $I_{N a L}$ & $\begin{array}{l}\text { Inhibiting nNOS-dependent } \\
\text { S-nitrosylation of } \mathrm{Na}_{\mathrm{v}} 1.5\end{array}$ & {$[187,451]$} \\
\hline
\end{tabular}

\section{Conclusions and Perspectives}

Understanding the complex cellular and molecular mechanisms by which the cardiac sodium channel is formed is essential for dissecting and eventually repairing the culprits of an important array of cardiac arrhythmogenic defects with a large impact on society, such as sudden death. In this review, we have provided current state-of-the-art information of the molecular events that emanate with the transcription and transcriptional regulation of the SCN5A gene, the post-transcriptional modifications that the SCN5A transcript undergoes leading to the configuration of a large array of distinct alternative spliced variants and being subjected to several types of epigenetic modulations along the way. Subsequently, distinct interacting proteins accompany the nascent $\mathrm{Na}_{\mathrm{v}} 1.5$ protein along with different subcellular organelles until it reaches its final membrane destination, accumulating a large number of diverse post-translational modifications, which eventually allows to carry out a fundamental electrophysiological role on the configuration of the cardiac action potential. Importantly, defects on a large number of these pathways have a tremendous impact on $\mathrm{Na}_{\mathrm{v}} 1.5$ functionality and are thus intimately linked to cardiac arrhythmias. While the advancement of the knowledge of the cardiac sodium channel biology and electrophysiology has greatly increased over the last two decades, understanding of the functional contribution of multiple SCN5A mutations as well as mutations in SCN5A/Na 1.5 interacting proteins is still incipient. In this context, it is particularly challenging to deeply understand the molecular mechanisms driving the association of single mutations with distinct impaired electrophysiological entities, such as Brugada and LQT syndrome, or in cases of even more complex phenotypical manifestations, such as sick sinus syndrome, atrial fibrillation, and ventricular tachycardia. In the coming years, insights into distinct molecular mechanisms involved in $S C N 5 A / \mathrm{Na}_{\mathrm{v}} 1.5$ formation and maturation will be more deeply explored, providing us with an increased understanding of the molecular and cellular routes that, if impaired, lead to distinct cardiac electrophysiological pathophysiologies, particularly on our currently poorly explored such as ventricular fibrillation, sick sinus syndrome, and sudden infant cardiac death. We also envision that the impact of non-coding biology into the modulation of $S C N 5 A / \mathrm{Na}_{\mathrm{v}} 1.5$ will progressively emerge, providing novel therapeutic tools to repair or at least modulate the pathological consequences of severe arrhythmogenic defects such as long QT, Brugada syndrome, and/or atrial fibrillation. 
Author Contributions: All authors contributed equally to the writing, review and editing of this work. All authors have read and agreed to the published version of the manuscript.

Funding: This research received no external funding.

Institutional Review Board Statement: Not applicable.

Informed Consent Statement: Not applicable.

Conflicts of Interest: The authors declare no conflict of interest.

$\begin{array}{ll}\text { Abbreviations } \\ \text { AP } & \text { Action potential } \\ \text { VS } & \text { Voltage-sensing module } \\ \text { PM } & \text { Pore module } \\ \text { PUFA } & \text { Polyunsaturated fatty acids } \\ \text { ER } & \text { Endoplasmic reticulum } \\ \text { RE } & \text { Regulatory elements } \\ \text { UPR } & \text { Unfolded protein response } \\ \text { ERAD } & \text { ER-associated degradation pathway } \\ \text { PTMs } & \text { Post-translational modifications } \\ \text { ID } & \text { Intercalated discs } \\ \text { LM } & \text { Lateral membrane } \\ I_{k s} & \text { Slow component of the delayed rectifier potassium current } \\ I_{t o} & \text { Transient outward potassium current }\end{array}$

\section{References}

1. Catterall, W.A.; Maier, S. Voltage-Gated Sodium Channels and Electrical Excitability of the Heart. In Cardiac Electrophysiology: From Cell to Bedside, 7th ed.; WB Saunders: Philadelphia, PA, USA, 2015; pp. 1-11. [CrossRef]

2. Fozzard, H.A.; Hanck, D.A. Structure and function of voltage-dependent sodium channels: Comparison of brain II and cardiac isoforms. Physiol. Rev. 1996, 76, 887-926. [CrossRef]

3. Gavillet, B.; Rougier, J.S.; Domenighetti, A.A.; Behar, R.; Boixel, C.; Ruchat, P.; Lehr, H.A.; Pedrazzini, T.; Abriel, H. Cardiac sodium channel $\mathrm{Na}_{\mathrm{v}} 1.5$ is regulated by a multiprotein complex composed of syntrophins and dystrophin. Circ. Res. 2006, 99, 407-414. [CrossRef]

4. $\quad$ Gellens, M.E.; George, A.L.; Chen, L.; Chahine, M.; Horn, R.; Barchi, R.L.; Kallen, R.G. Primary structure and functional expression of the human cardiac tetrodotoxin-insensitive voltage-dependent sodium channel. Proc. Natl. Acad. Sci. USA 1992, 89, 554-558. [CrossRef]

5. Jiang, D.; Shi, H.; Tonggu, L.; Gamal El-Din, T.M.; Lenaeus, M.J.; Zhao, Y.; Yoshioka, C.; Zheng, N.; Catterall, W.A. Structure of the Cardiac Sodium Channel. Cell 2020, 180, 122-134.e10. [CrossRef]

6. Bohannon, B.M.; de la Cruz, A.; Wu, X.; Jowais, J.J.; Perez, M.E.; Dykxhoorn, D.M.; Liin, S.I.; Larsson, H.P. Erratum: Correction: Polyunsaturated fatty acid analogues differentially affect cardiac $\mathrm{NaV}, \mathrm{CaV}$, and $\mathrm{KV}$ channels through unique mechanisms. eLife 2020, 9, e60141. [CrossRef]

7. Kang, J.X.; Leaf, A. Evidence that free polyunsaturated fatty acids modify $\mathrm{Na}^{+}$channels by directly binding to the channel proteins. Proc. Natl. Acad. Sci. USA 1996, 93, 3542-3546. [CrossRef] [PubMed]

8. Guan, Y.; Gao, X.; Tang, Q.; Huang, L.; Gao, S.; Yu, S.; Huang, J.; Li, J.; Zhou, D.; Zhang, Y.; et al. Nucleoporin 107 facilitates the nuclear export of Scn5a mRNA to regulate cardiac bioelectricity. J. Cell. Mol. Med. 2019, 23, 1448-1457. [CrossRef] [PubMed]

9. Yu, G.; Liu, Y.; Qin, J.; Wang, Z.; Hu, Y.; Wang, F.; Li, Y.; Chakrabarti, S.; Chen, Q.; Wang, Q.K. Mechanistic insights into the interaction of the MOG1 protein with the cardiac sodium channel $\mathrm{Na}_{\mathrm{v}} 1.5$ clarify the molecular basis of Brugada syndrome. J. Biol. Chem. 2018, 293, 18207-18217. [CrossRef]

10. Kurokawa, K.; Nakano, A. The ER exit sites are specialized ER zones for the transport of cargo proteins from the ER to the Golgi apparatus. J. Biochem. 2019, 165, 109-114. [CrossRef] [PubMed]

11. Dong, C.; Wang, Y.; Ma, A.; Wang, T. Life Cycle of the Cardiac Voltage-Gated Sodium Channel Na 1 1.5. Front. Physiol. 2020, 11, 609733. [CrossRef]

12. Clark, K.A.; McElhinny, A.S.; Beckerle, M.C.; Gregorio, C.C. Striated muscle cytoarchitecture: An intricate web of form and function. Annu. Rev. Cell Dev. Biol. 2002, 18, 637-706. [CrossRef] [PubMed]

13. Balse, E.; Eichel, C. The Cardiac Sodium Channel and Its Protein Partners. In Handbook of Experimental Pharmacology; Springer: Cham, Switzerland, 2017; pp. 251-263. [CrossRef]

14. Song, W.; Shou, W. Cardiac sodium channel $\mathrm{Na}_{\mathrm{v}} 1.5$ mutations and cardiac arrhythmia. Pediatr. Cardiol. 2012, 33, 943-949. [CrossRef] [PubMed] 
15. Balser, J.R. The cardiac sodium channel: Gating function and molecular pharmacology. J. Mol. Cell. Cardiol. 2001, 33, 599-613. [CrossRef] [PubMed]

16. Chahine, M.; George, A.L.; Zhou, M.; Ji, S.; Sun, W.; Barchi, R.L.; Horn, R. Sodium channel mutations in paramyotonia congenita uncouple inactivation from activation. Neuron 1994, 12, 281-294. [CrossRef]

17. Yang, N.; Horn, R. Evidence for voltage-dependent S4 movement in sodium channels. Neuron 1995, 15, 213-218. [CrossRef]

18. Albert, C.; Ruben, P.C.; George, A.L.; Fujimoto, E.; Bezanilla, F. Voltage sensors in domains III and IV, but not I and II, are immobilized by $\mathrm{Na}^{+}$channel fast inactivation. Neuron 1999, 22, 73-87. [CrossRef]

19. Armstrong, C.M.; Bezanilla, F. Inactivation of the sodium channel: II. gating current experiments. J. Gen. Physiol. 1977, 70, 567-590. [CrossRef]

20. Armstrong, C.M.; Wm Gilly, F. Fast and slow steps in the activation of sodium channels. J. Gen. Physiol. 1979, 74, 691-711. [CrossRef]

21. Hodgkin, A.L.; Huxley, A.F. Currents carried by sodium and potassium ions through the membrane of the giant axon of Loligo. J. Physiol. 1952, 116, 449-472. [CrossRef]

22. Kapplinger, J.D.; Tester, D.J.; Alders, M.; Benito, B.; Berthet, M.; Brugada, J.; Brugada, P.; Fressart, V.; Guerchicoff, A.; Harris-Kerr, C.; et al. An international compendium of mutations in the SCN5A-encoded cardiac sodium channel in patients referred for Brugada syndrome genetic testing. Heart Rhythm 2010, 7, 33-46. [CrossRef]

23. Kroncke, B.M.; Glazer, A.M.; Smith, D.K.; Blume, J.D.; Roden, D.M. SCN5A (Na 1.5$)$ Variant Functional Perturbation and Clinical Presentation: Variants of a Certain Significance. Circ. Genom. Precis. Med. 2018, 11, e002095. [CrossRef]

24. Remme, C.A.; Verkerk, A.O.; Nuyens, D.; van Ginneken, A.C.G.; van Brunschot, S.; Belterman, C.N.W.; Wilders, R.; van Roon, M.A.; Tan, H.L.; Wilde, A.A.M.; et al. Overlap Syndrome of Cardiac Sodium Channel Disease in Mice Carrying the Equivalent Mutation of Human SCN5A -1795insD. Circulation 2006, 114, 2584-2594. [CrossRef] [PubMed]

25. Chen, Q.; Kirsch, G.E.; Zhang, D.; Brugada, R.; Brugada, J.; Brugada, P.; Potenza, D.; Moya, A.; Borggrefe, M.; Breithardt, G.; et al. Genetic basis and molecular mechanism for idiopathic ventricular fibrillation. Nature 1998, 392, 293-296. [CrossRef] [PubMed]

26. Bezzina, C.; Veldkamp, M.W.; van den Berg, M.P.; Postma, A.V.; Rook, M.B.; Viersma, J.-W.; van Langen, I.M.; Tan-Sindhunata, G.; Bink-Boelkens, M.T.E.; van der Hout, A.H.; et al. A Single $\mathrm{Na}^{+}$Channel Mutation Causing Both Long-QT and Brugada Syndromes. Circ. Res. 1999, 85, 1206-1213. [CrossRef]

27. Schott, J.; Alshinawi, C.; Kyndt, F.; Probst, V.; Hoorntje, T.M.; Hulsbeek, M.; Wilde, A.A.M.; Escande, D.; Mannens, M.M.A.M.; Le Marec, H. Cardiac conduction defects associate with mutations in SCN5A. Nat. Genet. 1999, 23, 20-21. [CrossRef]

28. Tan, H.L.; Bink-Boelkens, M.T.E.; Bezzina, C.R.; Viswanathan, P.C.; Beaufort-Krol, G.C.M.; Van Tintelen, P.J.; Van Den Berg, M.P.; Wilde, A.A.M.; Balser, J.R. A sodium-channel mutation causes isolated cardiac conduction disease. Nature 2001, 409, 1043-1047. [CrossRef]

29. Benson, D.W.; Wang, D.W.; Dyment, M.; Knilans, T.K.; Fish, F.A.; Strieper, M.J.; Rhodes, T.H.; George, A.L. Congenital sick sinus syndrome caused by recessive mutations in the cardiac sodium channel gene (SCN5A). J. Clin. Investig. 2003, 112, 1019-1028. [CrossRef]

30. Smits, J.P.P.; Koopmann, T.T.; Wilders, R.; Veldkamp, M.W.; Opthof, T.; Bhuiyan, Z.A.; Mannens, M.M.A.M.; Balser, J.R.; Tan, H.L.; Bezzina, C.R.; et al. A mutation in the human cardiac sodium channel (E161K) contributes to sick sinus syndrome, conduction disease and Brugada syndrome in two families. J. Mol. Cell. Cardiol. 2005, 38, 969-981. [CrossRef]

31. Wang, Q.; Shen, J.; Splawski, I.; Atkinson, D.; Li, Z.; Robinson, J.L.; Moss, A.J.; Towbin, J.A.; Keating, M.T. SCN5A mutations associated with an inherited cardiac arrhythmia, long QT syndrome. Cell 1995, 80, 805-811. [CrossRef]

32. Mann, S.A.; Castro, M.L.; Ohanian, M.; Guo, G.; Zodgekar, P.; Sheu, A.; Stockhammer, K.; Thompson, T.; Playford, D.; Subbiah, R.; et al. R222Q SCN5A mutation is associated with reversible ventricular ectopy and dilated cardiomyopathy. J. Am. Coll. Cardiol. 2012, 60, 1566-1573. [CrossRef] [PubMed]

33. Swan, H.; Amarouch, M.Y.; Leinonen, J.; Marjamaa, A.; Kucera, J.P.; Laitinen-Forsblom, P.J.; Lahtinen, A.M.; Palotie, A.; Kontula, K.; Toivonen, L.; et al. Gain-of-function mutation of the SCN5A gene causes exercise-induced polymorphic ventricular arrhythmias. Circ. Cardiovasc. Genet. 2014, 7,771-781. [CrossRef]

34. Laurent, G.; Saal, S.; Amarouch, M.Y.; Béziau, D.M.; Marsman, R.F.J.; Faivre, L.; Barc, J.; Dina, C.; Bertaux, G.; Barthez, O.; et al. Multifocal ectopic Purkinje-related premature contractions: A new SCN5A-related cardiac channelopathy. J. Am. Coll. Cardiol. 2012, 60, 144-156. [CrossRef]

35. Makiyama, T.; Akao, M.; Shizuta, S.; Doi, T.; Nishiyama, K.; Oka, Y.; Ohno, S.; Nishio, Y.; Tsuji, K.; Itoh, H.; et al. A novel SCN5A gain-of-function mutation M1875T associated with familial atrial fibrillation. J. Am. Coll. Cardiol. 2008, 52, 1326-1334. [CrossRef]

36. Olson, T.M.; Michels, V.V.; Ballew, J.D.; Reyna, S.P.; Karst, M.L.; Herron, K.J.; Horton, S.C.; Rodeheffer, R.J.; Anderson, J.L. Sodium channel mutations and susceptibility to heart failure and atrial fibrillation. JAMA 2005, 293, 447-454. [CrossRef]

37. McNair, W.P.; Ku, L.; Taylor, M.R.G.; Fain, P.R.; Dao, D.; Wolfel, E.; Mestroni, L. SCN5A mutation associated with dilated cardiomyopathy, conduction disorder, and arrhythmia. Circulation 2004, 110, 2163-2167. [CrossRef]

38. Bezzina, C.R.; Rook, M.B.; Groenewegen, W.A.; Herfst, L.J.; Van der Wal, A.C.; Lam, J.; Jongsma, H.J.; Wilde, A.A.M.; Mannens, M.M.A.M. Compound heterozygosity for mutations (W156X and R225W) in SCN5A associated with severe cardiac conduction disturbances and degenerative changes in the conduction system. Circ. Res. 2003, 92, 159-168. [CrossRef] [PubMed] 
39. Clatot, J.; Zheng, Y.; Girardeau, A.; Liu, H.; Laurita, K.R.; Marionneau, C.; Deschênes, I. Mutant voltage-gated Na ${ }^{+}$channels can exert a dominant negative effect through coupled gating. Am. J. Physiol.-Heart Circ. Physiol. 2018, 315, H1250-H1257. [CrossRef] [PubMed]

40. Keller, D.I.; Kucera, J.P.; Benammar, N. Brugada syndrome and fever: Genetic and molecular characterization of patients carrying SCN5A mutations. Cardiovasc. Res. 2005, 67, 510-519. [CrossRef]

41. Doisne, N.; Grauso, M.; Mougenot, N.; Clergue, M.; Souil, C.; Coulombe, A.; Guicheney, P.; Neyroud, N. In vivo DominantNegative Effect of an SCN5A Brugada Syndrome Variant. Front. Physiol. 2021, 12, 1-13. [CrossRef] [PubMed]

42. Neill, M.J.O.; Muhammad, A.; Li, B.; Wada, Y.; Hall, L.; Solus, J.F.; Short, L.; Roden, D.M.; Glazer, A.M. Dominant negative effects of SCN5A missense variants. bioRxiv 2021. [CrossRef]

43. Galleano, I.; Harms, H.; Choudhury, K.; Khoo, K.; Delemotte, L.; Pless, S.A. Functional cross-talk between phosphorylation and disease-causing mutations in the cardiac sodium channel $\mathrm{Na}_{\mathrm{v}}$ 1.5. Proc. Natl. Acad. Sci. USA 2021, 118, e2025320118. [CrossRef]

44. Van der Harst, P.; van Setten, J.; Verweij, N.; Vogler, G.; Franke, L.; Maurano, M.T.; Wang, X.; Mateo Leach, I.; Eijgelsheim, M.; Sotoodehnia, N.; et al. 52 Genetic Loci Influencing Myocardial Mass A. J. Am. Coll. Cardiol. 2016, 68, 1435-1448. [CrossRef]

45. Van Den Boogaard, M.; Smemo, S.; Burnicka-Turek, O.; Arnolds, D.E.; Van De Werken, H.J.G.; Klous, P.; McKean, D.; Muehlschlegel, J.D.; Moosmann, J.; Toka, O.; et al. A common genetic variant within SCN10A modulates cardiac SCN5A expression. J. Clin. Investig. 2014, 124, 1844-1852. [CrossRef]

46. Van Den Boogaard, M.; Barnett, P.; Vincent, M.; Van Den Boogaard, M.; Wong, L.Y.E.; Tessadori, F.; Bakker, M.L. Genetic variation in T-box binding element functionally affects SCN5A/SCN10A enhancer Find the latest version: Genetic variation in T-box binding element functionally affects SCN5A/SCN10A enhancer. J. Clin. Investig. 2012, 122, 2519-2530. [CrossRef]

47. Verweij, N.; Leach, I.M.; Van Den Boogaard, M.; Van Veldhuisen, D.J.; Christoffels, V.M.; Hillege, H.L.; Van Gilst, W.H.; Barnett, P.; De Boer, R.A.; Van Der Harst, P. Genetic Determinants of P Wave Duration and PR Segment. Circ. Cardiovasc. Genet. 2014, 7, 475-481. [CrossRef]

48. van Setten, J.; Brody, J.A.; Jamshidi, Y.; Swenson, B.R.; Butler, A.M.; Campbell, H.; Del Greco, F.M.; Evans, D.S.; Gibson, Q.; Gudbjartsson, D.F.; et al. PR interval genome-wide association meta-analysis identifies 50 loci associated with atrial and atrioventricular electrical activity. Nat. Commun. 2018, 9, 1-11. [CrossRef]

49. Man, J.C.; Mohan, R.A.; van den Boogaard, M.; Hilvering, C.R.; Jenkins, C.; Wakker, V.; Bianchi, V.; de Laat, W.; Barnett, P.; Boukens, B.J.; et al. An enhancer cluster controls gene activity and topology of the SCN5A-SCN10A locus in vivo. Nat. Commun. 2019, 10, 4943. [CrossRef]

50. Lister, R.; Pelizzola, M.; Dowen, R.H.; Hawkins, R.D.; Hon, G.; Tonti-Filippini, J.; Nery, J.R.; Lee, L.; Ye, Z.; Ngo, Q.M.; et al. Human DNA methylomes at base resolution show widespread epigenomic differences. Nature 2009, 462, 315-322. [CrossRef] [PubMed]

51. Postma, A.V.; Bezzina, C.R.; Christoffels, V.M. Genetics of congenital heart disease: The contribution of the noncoding regulatory genome. J. Hum. Genet. 2016, 61, 13-19. [CrossRef] [PubMed]

52. Bezzina, C.R.; Barc, J.; Mizusawa, Y.; Remme, C.A.; Gourraud, J.B.; Simonet, F.; Verkerk, A.O.; Schwartz, P.J.; Crotti, L.; Dagradi, F.; et al. Common variants at $S C N 5 A-S C N 10 A$ and HEY2 are associated with Brugada syndrome, a rare disease with high risk of sudden cardiac death. Nat Genet. 2013, 45, 1044-1049. [CrossRef] [PubMed]

53. Gilsbach, R.; Preissl, S.; Grüning, B.A.; Schnick, T.; Burger, L.; Benes, V.; Würch, A.; Bönisch, U.; Günther, S.; Backofen, R.; et al. Dynamic DNA methylation orchestrates cardiomyocyte development, maturation and disease. Nat. Commun. 2014, 5, 5288. [CrossRef]

54. Carreras, D.; Martinez-Moreno, R.; Pinsach-Abuin, M.L.; Santafe, M.M.; Gomà, P.; Brugada, R.; Scornik, F.S.; Pérez, G.J.; Pagans, S. Epigenetic changes governing Scn5a expression in denervated skeletal muscle. Int. J. Mol. Sci. 2021, 22, 2755. [CrossRef]

55. Salvarani, N.; Crasto, S.; Miragoli, M.; Bertero, A.; Paulis, M.; Kunderfranco, P.; Serio, S.; Forni, A.; Lucarelli, C.; Dal Ferro, M.; et al. The K219T-Lamin mutation induces conduction defects through epigenetic inhibition of SCN5A in human cardiac laminopathy. Nat. Commun. 2019, 10, 1-16. [CrossRef]

56. Arnolds, D.E.; Liu, F.; Fahrenbach, J.P.; Kim, G.H.; Schillinger, K.J.; Smemo, S.; McNally, E.M.; Nobrega, M.A.; Patel, V.V.; Moskowitz, I.P. TBX5 drives Scn5a expression to regulate cardiac conduction system function. J. Clin. Investig. 2012, 122, 2509-2518. [CrossRef]

57. Moskowitz, I.P.G.; Pizard, A.; Patel, V.V.; Bruneau, B.G.; Kim, J.B.; Kupershmidt, S.; Roden, D.; Berul, C.I.; Seidman, C.E.; Seidman, J.G. The T-Box transcription factor Tbx 5 is required for the patterning and maturation of the murine cardiac conduction system. Development 2004, 131, 4107-4116. [CrossRef] [PubMed]

58. Steimle, J.D.; Moskowitz, I.P. TBX5: A Key Regulator of Heart Development. Curr. Top. Dev. Biol. 2017, 122, 195-221. [CrossRef] [PubMed]

59. Brewer, A.; Pizzey, J. GATA factors in vertebrate heart development and disease. Expert Rev. Mol. Med. 2006, 8, 1-20. [CrossRef]

60. Garg, V.; Kathiriya, I.S.; Barnes, R.; Schluterman, M.K.; King, I.N.; Butler, C.A.; Rothrock, C.R.; Eapen, R.S.; Hirayama-Yamada, K.; Joo, K.; et al. GATA4 mutations cause human congenital heart defects and reveal an interaction with TBX5. Nature 2003, 424, 443-447. [CrossRef]

61. Tarradas, A.; Pinsach-Abuin, M.; Mackintosh, C.; Llora-Batlle, O.; Perez-Serra, A.; Batlle, M.; Pérez-Villa, F.; Zimmer, T.; GarciaBassets, I.; Brugada, R.; et al. Transcriptional regulation of the sodium channel gene (SCN5A) by GATA4 in human heart. J. Mol. Cell. Cardiol. 2017, 102, 74-82. [CrossRef] 
62. Zhou, A.; Shi, G.; Kang, G.J.; Xie, A.; Liu, H.; Jiang, N.; Liu, M.; Jeong, E.M.; Dudley, S.C. RNA binding protein, HuR, regulates SCN5A expression through stabilizing MEF2C transcription factor mRNA. J. Am. Heart Assoc. 2018, 7, 1-12. [CrossRef] [PubMed]

63. Zhou, A.; Xie, A.; Kim, T.; Liu, H.; Shi, G.; Kang, G.; Jiang, N.; Liu, M.; Jeong, E.; Choi, B.; et al. HuR-mediated SCN5A mRNA stability reduces arrhythmic risk in heart failure. Heart Rhythm 2018, 15, 1072-1080. [CrossRef]

64. Gaborit, N.; Sakuma, R.; Wylie, J.N.; Kim, K.H.; Zhang, S.S.; Hui, C.C.; Bruneau, B.G. Cooperative and antagonistic roles for Irx3 and Irx5 in cardiac morphogenesis and postnatal physiology. Development 2012, 139, 4007-4019. [CrossRef]

65. Koizumi, A.; Sasano, T.; Kimura, W.; Miyamoto, Y.; Aiba, T.; Ishikawa, T.; Nogami, A.; Fukamizu, S.; Sakurada, H.; Takahashi, Y.; et al. Genetic defects in a His-Purkinje system transcription factor, IRX3, cause lethal cardiac arrhythmias. Eur. Heart J. 2016, 37, 1469-1475. [CrossRef]

66. Cai, B.; Wang, N.; Mao, W.; You, T.; Lu, Y.; Li, X.; Ye, B.; Li, F.; Xu, H. Deletion of FoxO1 leads to shortening of QRS by increasing $\mathrm{Na}^{+}$channel activity through enhanced expression of both cardiac $\mathrm{Na}_{\mathrm{v}} 1.5$ and $\beta 3$ subunit. J. Mol. Cell. Cardiol. 2014, 74, 297-306. [CrossRef] [PubMed]

67. Mao, W.; You, T.; Ye, B.; Li, X.; Dong, H.H.; Hill, J.A.; Li, F.; Xu, H. Reactive oxygen species suppress cardiac $\mathrm{Na}_{\mathrm{v}} 1.5$ expression through Foxo1. PLoS ONE 2012, 7, e32738. [CrossRef]

68. Atack, T.C.; Stroud, D.M.; Watanabe, H.; Yang, T.; Hall, L.; Susan, B.; Lowe, J.S.; Leake, B.; Magnuson, M.A.; Yang, P.; et al. Informatic and Functional Approaches to Identifying a Regulatory Region for the Cardiac Sodium Channel. Circ. Res. 2012, 109, 38-46. [CrossRef]

69. Hesse, M.; Kondo, C.S.; Clark, R.B.; Su, L.; Allen, F.L.; Geary-Joo, C.T.M.; Kunnathu, S.; Severson, D.L.; Nygren, A.; Giles, W.R.; et al. Dilated cardiomyopathy is associated with reduced expression of the cardiac sodium channel Scn5a. Cardiovasc. Res. 2007, 75, 498-509. [CrossRef] [PubMed]

70. Nieto, M.A. The snail superfamily of zinc-finger transcription factors. Nat. Rev. Mol. Cell Biol. 2002, 3, 155-166. [CrossRef] [PubMed]

71. Schroeter, A.; Walzik, S.; Blechschmidt, S.; Haufe, V.; Benndorf, K.; Zimmer, T. Structure and function of splice variants of the cardiac voltage-gated sodium channel $\mathrm{Na}_{\mathrm{v}}$ 1.5. J. Mol. Cell. Cardiol. 2010, 49, 16-24. [CrossRef] [PubMed]

72. Makielski, J.C.; Ye, B.; Valdivia, C.R.; Pagel, M.D.; Pu, J.; Tester, D.J.; Ackerman, M.J. A Ubiquitous Splice Variant and a Common Polymorphism Affect Heterologous Expression of Recombinant Human SCN5A Heart Sodium Channels. Circ. Res. 2003, 93, 821-828. [CrossRef]

73. Camacho, J.A.; Hensellek, S.; Rougier, J.S.; Blechschmidt, S.; Abriel, H.; Benndorf, K.; Zimmer, T. Modulation of Na 1.5 channel function by an alternatively spliced sequence in the DII/DIII linker region. J. Biol. Chem. 2006, 281, 9498-9506. [CrossRef] [PubMed]

74. Blechschmidt, S.; Haufe, V.; Benndorf, K.; Zimmer, T. Voltage-gated $\mathrm{Na}^{+}$channel transcript patterns in the mammalian heart are species-dependent. Prog. Biophys. Mol. Biol. 2008, 98, 309-318. [CrossRef]

75. Chioni, A.M.; Fraser, S.P.; Pani, F.; Foran, P.; Wilkin, G.P.; Diss, J.K.J.; Djamgoz, M.B.A. A novel polyclonal antibody specific for the $\mathrm{Na}_{\mathrm{v}} 1.5$ voltage-gated $\mathrm{Na}^{+}$channel "neonatal" splice form. J. Neurosci. Methods 2005, 147, 88-98. [CrossRef]

76. Onkal, R.; Mattis, J.H.; Fraser, S.P.; Diss, J.K.J.; Shao, D.; Okuse, K.; Djamgoz, M.B.A. Alternative splicing of Na ${ }_{\mathrm{v}} 1.5:$ An electrophysiological comparison of "neonatal" and "adult" isoforms and critical involvement of a lysine residue. J. Cell. Physiol. 2008, 216, 716-726. [CrossRef]

77. Zimmer, T.; Bollensdorff, C.; Haufe, V.; Birch-Hirschfeld, E.; Benndorf, K. Mouse heart $\mathrm{Na}^{+}$channels: Primary structure and function of two isoforms and alternatively spliced variants. Am. J. Physiol.-Heart Circ. Physiol. 2002, 282, 1007-1017. [CrossRef]

78. Wang, J.; Ou, S.W.; Wang, Y.J.; Zong, Z.H.; Lin, L.; Kameyama, M.; Kameyama, A. New variants of Na $1.5 / S C N 5 A$ encode Na channels in the brain. J. Neurogenet. 2008, 22, 57-75. [CrossRef] [PubMed]

79. Wang, J.; Ou, S.W.; Wang, Y.J.; Kameyama, M.; Kameyama, A.; Zong, Z.H. Analysis of four novel variants of Na $1.5 / S C N 5 A$ cloned from the brain. Neurosci. Res. 2009, 64, 339-347. [CrossRef] [PubMed]

80. Shang, L.L.; Pfahnl, A.E.; Sanyal, S.; Jiao, Z.; Allen, J.; Banach, K.; Fahrenbach, J.; Weiss, D.; Taylor, W.R.; Zafari, A.M.; et al. Human Heart Failure Is Associated With Abnormal C-Terminal Splicing Variants in the Cardiac Sodium Channel. Physiology 2007, 101, 1146-1154. [CrossRef]

81. Montañés-Agudo, P.; Casini, S.; Aufiero, S.; Ernault, A.C.; van der Made, I.; Pinto, Y.M.; Remme, C.A.; Creemers, E.E. Inhibition of minor intron splicing reduces $\mathrm{Na}^{+}$and $\mathrm{Ca}^{2+}$ channel expression and function in cardiomyocytes. J. Cell Sci. 2021, 135, 259191. [CrossRef]

82. Wang, Z.; Luo, X.; Lu, Y.; Yang, B. miRNAs at the heart of the matter. J. Mol. Med. 2008, 86, 771-783. [CrossRef] [PubMed]

83. Yang, B.; Lu, Y.; Wang, Z. Control of cardiac excitability by microRNAs. Cardiovasc. Res. 2008, 79, 571-580. [CrossRef]

84. Remme, C.A.; Bezzina, C.R. Sodium channel (Dys)function and cardiac arrhythmias. Cardiovasc. Ther. 2010, $28,287-294$. [CrossRef] [PubMed]

85. Boštjančič, E.; Zidar, N.; Štajer, D.; Glavač, D. MicroRNAs miR-1, miR-133a, miR-133b and miR-208 are dysregulated in human myocardial infarction. Cardiology 2010, 115, 163-169. [CrossRef]

86. Daimi, H.; Lozano-Velasco, E.; Haj Khelil, A.; Chibani, J.B.E.; Barana, A.; Amorós, I.; González De La Fuente, M.; Caballero, R.; Aranega, A.; Franco, D. Regulation of SCN5A by microRNAs: MiR-219 modulates SCN5A transcript expression and the effects of flecainide intoxication in mice. Heart Rhythm 2015, 12, 1333-1342. [CrossRef] [PubMed] 
87. Lozano-Velasco, E.; Hernández-Torres, F.; Daimi, H.; Serra, S.A.S.A.; Herraiz, A.; Hove-Madsen, L.; Aránega, A.; Franco, D. Pitx2 impairs calcium handling in a dose-dependent manner by modulating Wnt signalling. Cardiovasc. Res. 2016, 109, 55-66. [CrossRef]

88. Lozano-Velasco, E.; Wangensteen, R.; Quesada, A.; Garcia-Padilla, C.; Osorio, J.A.; Ruiz-Torres, M.D.; Aranega, A.; Franco, D. Hyperthyroidism, but not hypertension, impairs PITX2 expression leading to Wnt-microRNA-ion channel remodeling. PLoS ONE 2017, 12, e0188473. [CrossRef] [PubMed]

89. Chinchilla, A.; Daimi, H.; Lozano-velasco, E.; Dominguez, J.N.; Caballero, R.; Delpo, E.; Tamargo, J.; Cinca, J.; Hove-madsen, L.; Aranega, A.E.; et al. PITX2 Insufficiency Leads to Atrial Electrical and Structural Remodeling Linked to Arrhythmogenesis. Circ. Cardiovasc. Genet. 2011, 4, 269-279. [CrossRef]

90. Zhao, Y.; Huang, Y.; Li, W.; Wang, Z.; Zhan, S.; Zhou, M.; Yao, Y.; Zeng, Z.; Hou, Y.; Chen, Q.; et al. Post-transcriptional regulation of cardiac sodium channel gene SCN5A expression and function by miR-192-5p. Biochim. Biophys. Acta-Mol. Basis Dis. 2015, 1852, 2024-2034. [CrossRef]

91. Li, J.; Xu, C.; Liu, Y.; Li, Y.; Du, S.; Zhang, R.; Sun, Y.; Zhang, R.; Wang, Y.; Xue, H.; et al. Fibroblast growth factor 21 inhibited ischemic arrhythmias via targeting miR-143/EGR1 axis. Basic Res. Cardiol. 2020, 115, 1-17. [CrossRef]

92. Zhang, X.; Yoon, J.Y.; Morley, M.; McLendon, J.M.; Mapuskar, K.A.; Gutmann, R.; Mehdi, H.; Bloom, H.L.; Dudley, S.C.; Ellinor P.T.; et al. A common variant alters SCN5A-miR-24 interaction and associates with heart failure mortality. J. Clin. Investig. 2018, 128, 1154-1163. [CrossRef]

93. Daimi, H.; Khelil, A.H.; Neji, A.; Ben Hamda, K.; Maaoui, S.; Aranega, A.; Chibani, J.B.; Franco, D. Role of SCN5A coding and non-coding sequences in Brugada syndrome onset: What's behind the scenes? Biomed. J. 2019, 42, 252-260. [CrossRef] [PubMed]

94. Quinn, J.J.; Chang, H.Y. Unique features of long non-coding RNA biogenesis and function. Nat. Rev. Genet. 2016, 17, 47-62. [CrossRef] [PubMed]

95. Bär, C.; Chatterjee, S.; Thum, T. Long Noncoding RNAs in Cardiovascular Pathology, Diagnosis, and Therapy. Circulation 2016, 134, 1484-1499. [CrossRef]

96. Long, Q.Q.; Wang, H.; Gao, W.; Fan, Y.; Li, Y.F.; Ma, Y.; Yang, Y.; Shi, H.J.; Chen, B.R.; Meng, H.Y.; et al. Long noncoding RNA Kcna2 antisense RNA contributes to ventricular arrhythmias via silencing Kcna2 in rats with congestive heart failure. J. Am. Heart Assoc. 2017, 6, e005965. [CrossRef] [PubMed]

97. Zhu, P.; Yang, M.; Ren, H.; Shen, G.; Chen, J.; Zhang, J.; Liu, J.; Sun, C. Long noncoding RNA MALAT1 downregulates cardiac transient outward potassium current by regulating miR-200c/HMGB1 pathway. J. Cell. Biochem. 2018, 119, 10239-10249. [CrossRef] [PubMed]

98. Pan, Z. Binding of LncRNA-DACH1 to dystrophin impairs the membrane tra cking of $\mathrm{Na}_{\mathrm{v}} 1.5$ protein and increases ventricular arrhythmia susceptibility. Preprint 2021, 1-17. [CrossRef]

99. Schmidt, J.W.; Catterall, W.A. Palmitylation, sulfation, and glycosylation of the alpha subunit of the sodium channel. Role of post-translational modifications in channel assembly. J. Biol. Chem. 1987, 262, 13713-13723. [CrossRef]

100. Marionneau, C.; Abriel, H. Regulation of the cardiac $\mathrm{Na}^{+}$channel $\mathrm{Na}_{\mathrm{v}} 1.5$ by post-translational modifications. J. Mol. Cell. Cardiol. 2015, 82, 36-47. [CrossRef]

101. Abriel, H. Cardiac sodium channel $\mathrm{Na}_{\mathrm{v}} 1.5$ and interacting proteins: Physiology and pathophysiology. J. Mol. Cell. Cardiol. 2010, 48, 2-11. [CrossRef]

102. Delisle, B.P.; Anson, B.D.; Rajamani, S.; January, C.T. Biology of Cardiac Arrhythmias Ion Channel Protein Trafficking. Circ. Res. 2004, 94, 1418-1428. [CrossRef]

103. Jan, C.H.; Williams, C.C.; Weissman, J.S. Principles of ER cotranslational translocation revealed by proximity-specific ribosome profiling. Science 2014, 346, 716. [CrossRef] [PubMed]

104. Zhou, J.; Shin, H.G.; Yi, J.; Shen, W.; Williams, C.P.; Murray, K.T. Phosphorylation and putative ER retention signals are required for protein kinase A-mediated potentiation of cardiac sodium current. Circ. Res. 2002, 91, 540-546. [CrossRef] [PubMed]

105. Abriel, $\mathrm{H}$. Roles and regulation of the cardiac sodium channel $\mathrm{Na}_{\mathrm{v}} 1.5$ : Recent insights from experimental studies. Cardiovasc. Res. 2007, 76, 381-389. [CrossRef]

106. Fiona, S.; Cusdin, J.J.C.; Jackson, A.P. Trafficking and Cellular Distribution of Voltage-Gated Sodium Channels. Traffic 2008, 9 , 17-26. [CrossRef]

107. Herfst, L.J.; Rook, M.B.; Jongsma, H.J. Trafficking and functional expression of cardiac $\mathrm{Na}^{+}$channels. J. Mol. Cell. Cardiol. 2004, 36, 185-193. [CrossRef]

108. Ranek, M.J.; Stachowski, M.J.; Kirk, J.A.; Willis, M.S. The role of heat shock proteins and co-chaperones in heart failure. Phil. Trans. R. Soc. B 2017, 373, 20160530. [CrossRef]

109. Remme, C.A.; Wilde, A.A. Targeting sodium channels in cardiac arrhythmia. Curr. Opin. Pharmacol. 2014, 15, 53-60. [CrossRef]

110. Abriel, H.; Kass, R.S. Regulation of the voltage-gated cardiac sodium channel $\mathrm{Na}_{\mathrm{v}} 1.5$ by interacting proteins. Trends Cardiovasc. Med. 2005, 15, 35-40. [CrossRef]

111. Shinlapawittayatorn, K.; Dudash, L.A.; Du, X.X.; Heller, L.; Poelzing, S.; Ficker, E.; Deschênes, I. A novel strategy using cardiac sodium channel polymorphic fragments to rescue trafficking-deficient SCN5A Mutations. Circ. Cardiovasc. Genet. 2011, 4, 500-509. [CrossRef]

112. Moreau, A.; Keller, D.I.; Huang, H.; Fressart, V.; Schmied, C.; Timour, Q.; Chahine, M. Mexiletine differentially restores the trafficking defects caused by two Brugada syndrome mutations. Front. Pharmacol. 2012, 3, 1-8. [CrossRef] 
113. Mercier, A.; Clément, R.; Harnois, T.; Bourmeyster, N.; Bois, P.; Chatelier, $\mathrm{A} . \mathrm{Na}_{\mathrm{v}} 1.5$ channels can reach the plasma membrane through distinct N-glycosylation states. Biochim. Biophys. Acta-Gen. Subj. 2015, 1850, 1215-1223. [CrossRef]

114. Hartl, F.U.; Bracher, A.; Hayer-Hartl, M. Molecular chaperones in protein folding and proteostasis. Nature 2011, 475, 324-332. [CrossRef] [PubMed]

115. Young, J.C. The role of the cytosolic HSP70 chaperone system in diseases caused by misfolding and aberrant trafficking of ion channels. DMM Dis. Models Mech. 2014, 7, 319-329. [CrossRef] [PubMed]

116. Li, K.; Jiang, Q.; Bai, X.; Yang, Y.F.; Ruan, M.Y.; Cai, S.Q. Tetrameric Assembly of $\mathrm{K}^{+}$Channels Requires ER-Located Chaperone Proteins. Mol. Cell 2017, 65, 52-65. [CrossRef]

117. Tarone, G.; Brancaccio, M. Keep your heart in shape: Molecular chaperone networks for treating heart disease. Cardiovasc. Res. 2014, 102, 346-361. [CrossRef]

118. Penna, C.; Sorge, M.; Femminò, S.; Pagliaro, P.; Brancaccio, M. Redox aspects of chaperones in cardiac function. Front. Physiol 2018, 9, 1-15. [CrossRef]

119. Poelzing, S.; Forleo, C.; Samodell, M.; Dudash, L.; Sorrentino, S.; Anaclerio, M.; Troccoli, R.; Iacoviello, M.; Romito, R.; Guida, P.; et al. SCN5A polymorphism restores trafficking of a Brugada syndrome mutation on a separate gene. Circulation 2006, 114, 368-376. [CrossRef]

120. Valdivia, C.R.; Tester, D.J.; Rok, B.A.; Porter, C.-B.J.; Munger, T.M.; Jahangir, A.; Makielski, J.C.; Ackerman, M.J. A trafficking defective, Brugada syndrome-causing SCN5A mutation rescued by drugs. Cardiovasc. Res. 2004, 62, 53-62. [CrossRef]

121. Ulloa-Aguirre, A.; Janovick, J.A.; Brothers, S.P.; Conn, P.M. Pharmacologic rescue of conformationally-defective proteins: Implications for the treatment of human disease. Traffic 2004, 5, 821-837. [CrossRef]

122. Cohen, S.A.; Levitt, L.K. Partial characterization of the $\mathrm{rH} 1$ sodium channel protein from rat heart using subtype-specific antibodies. Circ. Res. 1993, 73, 735-742. [CrossRef]

123. Caramelo, J.J.; Parodi, A.J. A sweet code for glycoprotein folding. FEBS Lett. 2015, 589, 3379-3387. [CrossRef] [PubMed]

124. Verges, M. Trafficking of Cardiac Ion Channels; MDPI AG: Basel, Switzerland, 2021; ISBN 9783039434725.

125. Bennett, E.S. Isoform-specific effects of sialic acid on voltage-dependent $\mathrm{Na}^{+}$channel gating: Functional sialic acids are localized to the S5-S6 loop of domain I. J. Physiol. 2002, 538, 675-690. [CrossRef] [PubMed]

126. Stocker, P.J.; Bennett, E.S. Differential sialylation modulates voltage-gated $\mathrm{Na}^{+}$channel gating throughout the developing myocardium. J. Gen. Physiol. 2006, 127, 253-265. [CrossRef] [PubMed]

127. Arakel, E.C.; Brandenburg, S.; Uchida, K.; Zhang, H.; Lin, Y.W.; Kohl, T.; Schrul, B.; Sulkin, M.S.; Efimov, I.R.; Nichols, C.G.; et al. Tuning the electrical properties of the heart by differential trafficking of KATP ion channel complexes. J. Cell Sci. 2014, 127, 2106-2119. [CrossRef]

128. Roth, J.; Zuber, C.; Park, S.; Jang, I.; Lee, Y.; Kysela, K.G.; Le Fourn, V.; Santimaria, R.; Guhl, B.; Cho, J.W. Protein N-glycosylation, protein folding and protein quality control. Mol. Cells 2010, 30, 497-506. [CrossRef]

129. Xiao, X.; Chen, C.; Yu, T.M.; Ou, J.; Rui, M.; Zhai, Y.; He, Y.; Xue, L.; Ho, M.S. Molecular chaperone calnexin regulates the function of Drosophila sodium channel paralytic. Front. Mol. Neurosci. 2017, 10, 57. [CrossRef]

130. Khanna, R.; Lee, E.J.; Papazian, D.M. Transient calnexin interaction confers long-term stability on folded $\mathrm{K}^{+}$channel protein in the ER. J. Cell Sci. 2004, 117, 2897-2908. [CrossRef]

131. Proft, J.; Rzhepetskyy, Y.; Lazniewska, J.; Zhang, F.X.; Cain, S.M.; Snutch, T.P.; Zamponi, G.W.; Weiss, N. The Cacna1h mutation in the GAERS model of absence epilepsy enhances T-type $\mathrm{Ca}^{2+}$ currents by altering calnexin-dependent trafficking of $\mathrm{Ca}_{\mathrm{v}} 3.2$ channels. Sci. Rep. 2017, 7, 11513. [CrossRef] [PubMed]

132. Zumhagen, S.; Veldkamp, M.W.; Stallmeyer, B.; Baartscheer, A.; Eckardt, L.; Paul, M.; Remme, C.A.; Bhuiyan, Z.A.; Bezzina, C.R.; Schulze-Bahr, E. A Heterozygous Deletion Mutation in the Cardiac Sodium Channel Gene SCN5A with Loss- and Gain-ofFunction Characteristics Manifests as Isolated Conduction Disease, without Signs of Brugada or Long QT Syndrome. PLoS ONE 2013, 8, e67963. [CrossRef]

133. Casini, S.; Tan, H.L.; Demirayak, I.; Remme, C.A.; Amin, A.S.; Scicluna, B.P.; Chatyan, H.; Ruijter, J.M.; Bezzina, C.R.; Van Ginneken, A.C.G.; et al. Tubulin polymerization modifies cardiac sodium channel expression and gating. Cardiovasc. Res. 2010, 85, 691-700. [CrossRef]

134. Abriel, H.; Sottas, V. Unexpected $\alpha-\alpha$ interactions with nav1.5 genetic variants in brugada syndrome. Circ. Cardiovasc. Genet. 2014, 7, 97-99. [CrossRef]

135. Gao, G.; Xie, A.; Zhang, J.; Herman, A.M.; Jeong, E.M.; Gu, L.; Liu, M.; Yang, K.C.; Kamp, T.J.; Dudley, S.C. Unfolded protein response regulates cardiac sodium current in systolic human heart failure. Circ. Arrhythmia Electrophysiol. 2013, 6, 1018-1024. [CrossRef] [PubMed]

136. Ren, J.; Bi, Y.; Sowers, J.R.; Hetz, C.; Zhang, Y. Endoplasmic reticulum stress and unfolded protein response in cardiovascular diseases. Nat. Rev. Cardiol. 2021, 18, 499-521. [CrossRef] [PubMed]

137. Iqbal, S.M.; Lemmens-Gruber, R. Phosphorylation of cardiac voltage-gated sodium channel: Potential players with multiple dimensions. Acta Physiol. 2019, 225, 1-18. [CrossRef]

138. Schubert, B.; Vandongen, A.M.J.; Kirsch, G.E.; Brown, A.M. Inhibition of cardiac $\mathrm{Na}^{+}$currents by isoproterenol. Am. J. Physiol.Heart Circ. Physiol. 1990, 258. [CrossRef]

139. Frohnwieser, B.; Chen, L.Q.; Schreibmayer, W.; Kallen, R.G. Modulation of the human cardiac sodium channel $\alpha$-subunit by cAMP-dependent protein kinase and the responsible sequence domain. J. Physiol. 1997, 498, 309-318. [CrossRef] 
140. Murphy, B.J.; Rogers, J.; Perdichizzi, A.P.; Colvin, A.A.; Catterall, W.A. cAMP-dependent phosphorylation of two sites in the $\alpha$ subunit of the cardiac sodium channel. J. Biol. Chem. 1996, 271, 28837-28843. [CrossRef]

141. Tateyama, M.; Rivolta, I.; Clancy, C.E.; Kass, R.S. Modulation of Cardiac Sodium Channel Gating by Protein Kinase A Can Be Altered by Disease-linked Mutation. J. Biol. Chem. 2003, 278, 46718-46726. [CrossRef]

142. Rook, M.B.; Evers, M.M.; Vos, M.A.; Bierhuizen, M.F. Biology of cardiac sodium channel $\mathrm{Na}_{\mathrm{v}} 1.5$ expression. Cardiovasc. Res. 2012, 93, 12-23. [CrossRef]

143. Zhou, J.; Yi, J.; Hu, N.N.; George, A.L.; Murray, K.T. Activation of protein kinase A modulates trafficking of the human cardiac sodium channel in Xenopus oocytes. Circ. Res. 2000, 87, 33-38. [CrossRef] [PubMed]

144. Scott, D.B.; Blanpied, T.A.; Ehlers, M.D. Coordinated PKA and PKC phosphorylation suppresses RXR-mediated ER retention and regulates the surface delivery of NMDA receptors. Neuropharmacology 2003, 45, 755-767. [CrossRef]

145. Hallaqa, H.; Yanga, Z.; Viswanathanb, P.C.; Fukudab, K.; Shena, W.; Wanga, D.W.; Wellsc, K.S.; Zhoua, J.; Yia, J.; Hallaqa, K.T.M.; et al. Quantitation of protein kinase a mediated trafficking of cardiac sodium channels in living cells. Cardiovasc. Res. 2006, 72, 250-261. [CrossRef] [PubMed]

146. Qu, Y.; Rogers, J.; Tanada, T.; Scheuer, T.; Catterall, W.A. Modulation of cardiac $\mathrm{Na}^{+}$channels expressed in a mammalian cell line and in ventricular myocytes by protein kinase C. Proc. Natl. Acad. Sci. USA 1994, 91, 3289-3293. [CrossRef] [PubMed]

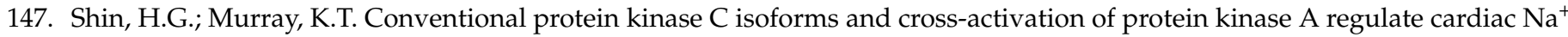
current. FEBS Lett. 2001, 495, 154-158. [CrossRef]

148. Xiao, G.Q.; Qu, Y.; Sun, Z.Q.; Mochly-Rosen, D.; Boutjdir, M. Evidence for functional role of $\varepsilon$ PKC isozyme in the regulation of cardiac $\mathrm{Na}^{+}$channels. Am. J. Physiol.-Cell Physiol. 2001, 281, C1477-C1486. [CrossRef]

149. Ferreira, J.C.B.; Mochly-Rosen, D.; Boutjdir, M. Regulation of cardiac excitability by protein kinase C isozymes. Front. Biosci.-Sch 2012, 4, 532-546. [CrossRef]

150. Liu, M.; Shi, G.; Yang, K.C.; Gu, L.; Kanthasamy, A.G.; Anantharam, V.; Dudley, S.C., Jr. The role of protein kinase C in the metabolic regulation of the cardiac $\mathrm{Na}^{+}$channel. Heart Rhythm 2017, 14, 440-447. [CrossRef] [PubMed]

151. Mathieu, S.; El Khoury, N.; Rivard, K.; Gélinas, R.; Goyette, P.; Paradis, P.; Nemer, M.; Fiset, C. Reduction in Na ${ }^{+}$current by angiotensin II is mediated by PKC $\alpha$ in mouse and human-induced pluripotent stem cell-derived cardiomyocytes. Heart Rhythm 2016, 13, 1346-1354. [CrossRef] [PubMed]

152. Qu, Y.; Rogers, J.C.; Tanada, T.N.; Catterall, W.A.; Scheuer, T. Phosphorylation of S1505 in the cardiac Na ${ }^{+}$channel inactivation gate is required for modulation by protein kinase C. J. Gen. Physiol. 1996, 108, 375-379. [CrossRef] [PubMed]

153. Murray, K.T.; Hu, N.; Daw, J.R.; Shin, H.G.; Watson, M.T.; Mashburn, A.B.; George, A.L. Functional effects of protein kinase C activation on the human cardiac $\mathrm{Na}^{+}$channel. Circ. Res. 1997, 80, 370-376. [CrossRef]

154. Liu, M.; Sanyal, S.; Gao, G.; Gurung, I.S.; Zhu, X.; Gaconnet, G.; Kerchner, L.J.; Shang, L.L.; Huang, C.L.H.; Grace, A.; et al. Cardiac $\mathrm{Na}^{+}$Current regulation by pyridine nucleotides. Circ. Res. 2009, 105, 737-745. [CrossRef]

155. Strickland, M.; Yacoubi-Loueslati, B.; Bouhaouala-Zahar, B.; Pender, S.L.F.; Larbi, A. Relationships between ion channels, mitochondrial functions and inflammation in human aging. Front. Physiol. 2019, 10, 1-22. [CrossRef] [PubMed]

156. Hu, Y.F.; Wu, C.H.; Lai, T.C.; Chang, Y.C.; Hwang, M.J.; Chang, T.Y.; Weng, C.H.; Chang, P.M.H.; Chen, C.H.; Mochly-Rosen, D.; et al. ALDH2 deficiency induces atrial fibrillation through dysregulated cardiac sodium channel and mitochondrial bioenergetics: A multi-omics analysis. Biochim. Biophys. Acta-Mol. Basis Dis. 2021, 1867, 166088. [CrossRef] [PubMed]

157. Valdivia, C.R.; Ueda, K.; Ackerman, M.J.; Makielski, J.C. GPD1L links redox state to cardiac excitability by PKCdependentphosphorylation of the sodium channel SCN5A. Am. J. Physiol. Heart Circ. Physiol. 2009, 297, H1446-H1452. [CrossRef] [PubMed]

158. Liu, M.; Liu, H.; Dudley, S.C. Reactive oxygen species originating from mitochondria regulate the cardiac sodium channel. Circ. Res. 2010, 107, 967-974. [CrossRef] [PubMed]

159. Liu, M.; Gu, L.; Sulkin, M.S.; Liu, H.; Jeong, E.M.; Greener, I.; Xie, A.; Efimov, I.R.; Dudley, S.C. Mitochondrial dysfunction causing cardiac sodium channel downregulation in cardiomyopathy. J. Mol. Cell. Cardiol. 2013, 54, 25-34. [CrossRef] [PubMed]

160. Matasic, D.S.; Yoon, J.Y.; McLendon, J.M.; Mehdi, H.; Schmidt, M.S.; Greiner, A.M.; Quinones, P.; Morgan, G.M.; Boudreau, R.L.; Irani, K.; et al. Modulation of the cardiac sodium channel $\mathrm{Na}_{\mathrm{v}} 1.5$ peak and late currents by $\mathrm{NAD}^{+}$precursors. J. Mol. Cell. Cardiol. 2020, 141, 70-81. [CrossRef]

161. Fouda, M.A.; Ghovanloo, M.R.; Ruben, P.C. Cannabidiol protects against high glucose-induced oxidative stress and cytotoxicity in cardiac voltage-gated sodium channels. Br. J. Pharmacol. 2020, 177, 2932-2946. [CrossRef]

162. Fouda, M.A.; Ruben, P.C. Protein kinases mediate anti-inflammatory effects of cannabidiol and estradiol against high glucose in cardiac sodium channels. Front. Pharmacol. 2021, 12, 1-17. [CrossRef]

163. Ashpole, N.M.; Herren, A.W.; Ginsburg, K.S.; Brogan, J.D.; Johnson, D.E.; Cummins, T.R.; Bers, D.M.; Hudmon, A $\mathrm{Ca}^{2+} /$ calmodulin-dependent protein kinase II (CaMKII) regulates cardiac sodium channel $\mathrm{Na}_{\mathrm{v}} 1.5$ gating by multiple phosphorylation sites. J. Biol. Chem. 2012, 287, 19856-19869. [CrossRef]

164. Herren, A.W.; Weber, D.M.; Rigor, R.R.; Margulies, K.B.; Phinney, B.S.; Bers, D.M. CaMKII Phosphorylation of Na $1.5: \mathrm{Novel}_{\mathrm{v}}$ Vitro Sites Identified by Mass Spectrometry and Reduced S516 Phosphorylation in Human Heart Failure. J. Proteome Res. 2015, 14, 2298-2311. [CrossRef] 
165. Burel, S.; Coyan, F.C.; Lorenzini, M.; Meyer, M.R.; Lichti, C.F.; Brown, J.H.; Loussouarn, G.; Charpentier, F.; Nerbonne, J.M.; Townsend, R.R.; et al. C-terminal phosphorylation of $\mathrm{Na}_{\mathrm{v}} 1.5$ impairs FGF13-dependent regulation of channel inactivation. J. Biol. Chem. 2017, 292, 17431-17448. [CrossRef]

166. Wagner, S.; Dybkova, N.; Rasenack, E.C.L.; Jacobshagen, C.; Fabritz, L.; Kirchhof, P.; Maier, S.K.G.; Zhang, T.; Hasenfuss, G.; Brown, J.H.; et al. $\mathrm{Ca}^{2+} /$ calmodulin-dependent protein kinase II regulates cardiac $\mathrm{Na}^{+}$channels. J. Clin. Investig. 2006, 116, 3127-3138. [CrossRef] [PubMed]

167. El Refaey, M.; Musa, H.; Murphy, N.P.; Lubbers, E.R.; Skaf, M.; Han, M.; Cavus, O.; Koenig, S.N.; Wallace, M.J.; Gratz, D.; et al. Protein Phosphatase 2A Regulates Cardiac $\mathrm{Na}^{+}$Channels. Circ. Res. 2019, 124, 737-746. [CrossRef] [PubMed]

168. Deschênes, I.; Neyroud, N.; DiSilvestre, D.; Marbán, E.; Yue, D.T.; Tomaselli, G.F. Isoform-specific modulation of voltage-gated $\mathrm{Na}^{+}$channels by calmodulin. Circ. Res. 2002, 90, 49-57. [CrossRef]

169. Ahern, C.A.; Zhang, J.F.; Wookalis, M.J.; Horn, R. Modulation of the cardiac sodium channel Na 1.5 by Fyn, a Src family tyrosine kinase. Circ. Res. 2005, 96, 991-998. [CrossRef] [PubMed]

170. Razani, B.; Woodman, S.E.; Lisanti, M.P. Caveolae: From cell biology to animal physiology. Pharmacol. Rev. 2002, 54, $431-467$. [CrossRef]

171. Maier, S.K.; Westenbroek, R.E.; Schenkman, K.A.; Feigl, E.O.; Scheuer, T.; Catterall, W.A. An unexpected role for brain type sodium channels in coupling of cell surface depolarization to contraction in the heart. Proc. Natl. Acad. Sci. USA 2002, 99, 4073-4078. [CrossRef]

172. Iqbal, S.M.; Andavan, G.S.B.; Lemmens-Gruber, R. Differential modulation of fast inactivation in cardiac sodium channel splice variants by fyn tyrosine kinase. Cell. Physiol. Biochem. 2015, 37, 825-837. [CrossRef]

173. Iqbal, S.M.; Aufy, M.; Shabbir, W.; Lemmens-Gruber, R. Identification of phosphorylation sites and binding pockets for modulation of $\mathrm{Na}_{\mathrm{v}} 1.5$ channel by Fyn tyrosine kinase. FEBS J. 2018, 285, 2520-2530. [CrossRef]

174. Sarhan, M.F.; Van Petegem, F.; Ahern, C.A. A double tyrosine motif in the cardiac sodium channel domain III-IV linker couples calcium-dependent calmodulin binding to inactivation gating. J. Biol. Chem. 2009, 284, 33265-33274. [CrossRef] [PubMed]

175. Jespersen, T.; Gavillet, B.; van Bemmelen, M.X.; Cordonier, S.; Thomas, M.A.; Staub, O.; Abriel, H. Cardiac sodium channel Na 1.5 interacts with and is regulated by the protein tyrosine phosphatase PTPH1. Biochem. Biophys. Res. Commun. 2006, 348, 1455-1462. [CrossRef] [PubMed]

176. Beltran-Alvarez, P.; Pagans, S.; Brugada, R. The cardiac sodium channel is post-translationally modified by arginine methylation. J. Proteome Res. 2011, 10, 3712-3719. [CrossRef] [PubMed]

177. Beltran-Alvarez, P.; Espejo, A.; Schmauder, R.; Beltran, C.; Mrowka, R.; Linke, T.; Batlle, M.; Pérez-Villa, F.; Pérez, G.J.; Scornik, F.S.; et al. Protein arginine methyl transferases- 3 and -5 increase cell surface expression of cardiac sodium channel. FEBS Lett. 2013, 587, 3159-3165. [CrossRef] [PubMed]

178. Beltran-Alvarez, P.; Tarradas, A.; Chiva, C.; Pérez-Serra, A.; Batlle, M.; Pérez-Villa, F.; Schulte, U.; Sabidó, E.; Brugada, R.; Pagans, S. Identification of N-terminal protein acetylation and arginine methylation of the voltage-gated sodium channel in end-stage heart failure human heart. Curr. Ther. Res.-Clin. Exp. 2014, 76, 126-129. [CrossRef]

179. Yoon, J.Y.; Vikram, A.; London, B.; Irani, K. Reversible lysine acetylation: Another layer of post-translational regulation of the cardiac sodium channel. Channels 2017, 11, 360-361. [CrossRef]

180. Vikram, A.; Lewarchik, C.M.; Yoon, J.-Y.; Naqvi, A.; Kumar, S.; Morgan, G.M.; Jacobs, J.S.; Li, Q.; Kim, Y.-R.; Kassan, M.; et al. Sirtuin 1 regulates cardiac electrical activity by deacetylating the cardiac sodium channel. Nat. Med. 2017, 23, 361-370. [CrossRef]

181. Henley, J.M.; Craig, T.J.; Wilkinson, K.A. Neuronal Sumoylation: Mechanisms, Dysfunction. Physiol. Rev. 2014, 94, 1249-1285. [CrossRef]

182. Plant, L.D.; Xiong, D.; Romero, J.; Dai, H.; Goldstein, S.A.N. Hypoxia Produces Pro-arrhythmic Late Sodium Current in Cardiac Myocytes by SUMOylation of $\mathrm{Na}_{\mathrm{v}} 1.5$ Channels. Cell Rep. 2020, 30, 2225-2236.e4. [CrossRef]

183. Hess, D.T.; Matsumoto, A.; Kim, S.O.; Marshall, H.E.; Stamler, J.S. Protein S-nitrosylation: Purview and parameters. Nat. Rev. Mol. Cell Biol. 2005, 6, 150-166. [CrossRef]

184. Nathan, C.; Xie, Q. wen Nitric oxide synthases: Roles, tolls, and controls. Cell 1994, 78, 915-918. [CrossRef]

185. Ahern, G.P.; Hsu, S.F.; Klyachko, V.A.; Jackson, M.B. Induction of persistent sodium current by exogenous and endogenous nitric oxide. J. Biol. Chem. 2000, 275, 28810-28815. [CrossRef] [PubMed]

186. Cheng, J.; Van Norstrand, D.W.; Medeiros-Domingo, A.; Valdivia, C.; Tan, B.; Ye, B.; Kroboth, S.; Vatta, M.; Tester, D.J.; January, C.T.; et al. $\alpha 1$-Syntrophin Mutations Identified in Sudden Infant Death Syndrome Cause an Increase in Late Cardiac Sodium Current. Circ. Arrhythmia Electrophysiol. 2009, 2, 667-676. [CrossRef]

187. Cheng, J.; Valdivia, C.R.; Vaidyanathan, R.; Balijepalli, R.C.; Ackerman, M.J.; Makielski, J.C. Caveolin-3 suppresses late sodium current by inhibiting nNOS-dependent S-nitrosylation of SCN5A. J. Mol. Cell. Cardiol. 2013, 61, 102-110. [CrossRef]

188. Wang, P.; Wei, M.; Zhu, X.; Liu, Y.; Yoshimura, K.; Zheng, M.; Liu, G.; Kume, S.; Morishima, M.; Kurokawa, T.; et al. Nitric oxide down-regulates voltage-gated $\mathrm{Na}^{+}$channel in cardiomyocytes possibly through S-nitrosylation-mediated signaling. Sci. Rep. 2021, 11, 11273. [CrossRef] [PubMed]

189. Krüger, E.; Hahn, K. Lipoxidation products as biomarkers of oxidative damage to proteins during lipid peroxidation reactions. Nephrol.-Dial.-Transplant. 2010, 11, 1-191. 
190. Herren, A.W.; Bers, D.M.; Grandi, E. Post-translational modifications of the cardiac Na channel: Contribution of CaMKIIdependent phosphorylation to acquired arrhythmias. Am. J. Physiol.-Heart Circ. Physiol. 2013, 305, H431-H445. [CrossRef] [PubMed]

191. Nakajima, T.; Davies, S.S.; Matafonova, E.; Potet, F.; Amarnath, V.; Tallman, K.A.; Serwa, R.A.; Porter, N.A.; Balser, J.R.; Kupershmidt, S.; et al. Selective $\gamma$-ketoaldehyde scavengers protect $\mathrm{Na}_{\mathrm{v}} 1.5$ from oxidant-induced inactivation. J. Mol. Cell. Cardiol. 2010, 48, 352-359. [CrossRef]

192. Quiñonez, M.; DiFranco, M.; González, F. Involvement of methionine residues in the fast inactivation mechanism of the sodium current from toad skeletal muscle fibers. J. Membr. Biol. 1999, 169, 83-90. [CrossRef]

193. Kassmann, M.; Hansel, A.; Leipold, E.; Birkenbeil, J.; Lu, S.Q.; Hoshi, T.; Heinemann, S.H. Oxidation of multiple methionine residues impairs rapidsodium channel inactivation. Pflugers Arch.-Eur. J. Physiol. 2008, 456, 1085-1095. [CrossRef]

194. Erickson, J.R.; Mei-ling, A.J.; Guan, X.; Kutschke, W.; Yang, J.; Oddis, C.V.; Bartlett, R.K.; Lowe, J.S.; O'Donnell, S.E.; Aykin-Burns, N.; et al. A Dynamic Pathway for Calcium-Independent Activation of CaMKII by Methionine Oxidation. Cell 2008, 133, 462-474. [CrossRef]

195. Chamberlain, L.H.; Shipston, M.J. The physiology of protein s-acylation. Physiol. Rev. 2015, 95, 341-376. [CrossRef] [PubMed]

196. Chen, L.; Bi, D.; Tian, L.; McClafferty, H.; Steeb, F.; Ruth, P.; Knaus, H.G.; Shipston, M.J. Palmitoylation of the $\beta 4$-subunit regulates surface expression of large conductance calcium-activated potassium channel splice variants. J. Biol. Chem. 2013, 288, 13136-13144. [CrossRef]

197. Pei, Z.; Xiao, Y.; Meng, J.; Hudmon, A.; Cummins, T.R. Cardiac sodium channel palmitoylation regulates channel availability and myocyte excitability with implications for arrhythmia generation. Nat. Commun. 2016, 7, 12035. [CrossRef] [PubMed]

198. Kahl, G. Protein truncation test (PTT; protein truncation assay, PTA). Dict. Genom. Transcr. Proteom. 2015, 1. [CrossRef]

199. Zimmer, T.; Biskup, C.; Dugarmaa, S.; Vogel, F.; Steinbis, M.; Böhle, T.; Wu, Y.S.; Dumaine, R.; Benndorf, K. Functional expression of GFP-linked human heart sodium channel (hH1) and subcellular localization of the $\alpha$ subunit in HEK293 cells and dog cardiac myocytes. J. Membr. Biol. 2002, 186, 1-12. [CrossRef]

200. Wu, L.; Yong, S.L.; Fan, C.; Ni, Y.; Yoo, S.; Zhang, T.; Zhang, X.; Obejero-Paz, C.A.; Rho, H.J.; Ke, T.; et al. Identification of a new co-factor, MOG1, required for the full function of cardiac sodium channel $\mathrm{Na}_{\mathrm{v}}$ 1.5. J. Biol. Chem. 2008, 283, 6968-6978. [CrossRef]

201. Chakrabarti, S.; Wu, X.; Yang, Z.; Wu, L.; Yong, S.L.; Zhang, C.; Hu, K.; Wang, Q.K.; Chen, Q. MOG1 Rescues Defective Trafficking of $\mathrm{Na}_{\mathrm{v}}$ 1.5 Mutations in Brugada Syndrome and Sick Sinus Syndrome. Circ. Arrhythmia Electrophysiol. 2013, 6, 392-401. [CrossRef]

202. Wang, Z.; Yu, G.; Liu, Y.; Liu, S.; Aridor, M.; Huang, Y.; Hu, Y.; Wang, L.; Li, S.; Xiong, H.; et al. Small GTPases SAR1A and SAR1B regulate the trafficking of the cardiac sodium channel $\mathrm{Na}_{\mathrm{v}}$ 1.5. Biochim. Biophys. Acta-Mol. Basis Dis. 2018, 1864, 3672-3684. [CrossRef]

203. Chatin, B.; Colombier, P.; Gamblin, A.L.; Allouis, M.; Le Bouffant, F. Dynamitin affects cell-surface expression of voltage-gated sodium channel $\mathrm{Na}_{\mathrm{v}}$ 1.5. Biochem. J. 2014, 463, 339-349. [CrossRef]

204. Ednie, A.R.; Horton, K.K.; Wu, J.; Bennett, E.S. Expression of the sialyltransferase, ST3Gal4, impacts cardiac voltage-gated sodium channel activity, refractory period and ventricular conduction. J. Mol. Cell. Cardiol. 2013, 59, 117-127. [CrossRef] [PubMed]

205. Baroni, D.; Picco, C.; Moran, O. A mutation of SCN1B associated with GEFS+ causes functional and maturation defects of the voltage-dependent sodium channel. Hum. Mutat. 2018, 39, 1402-1415. [CrossRef] [PubMed]

206. Rosnoblet, C.; Peanne, R.; Legrand, D.; Foulquier, F. Glycosylation disorders of membrane trafficking. Glycoconj. J. 2013, 30, 23-31. [CrossRef] [PubMed]

207. Bennett, E.; Urcan, M.S.; Tinkle, S.S.; Koszowski, A.G.; Levinson, S.R. Contribution of sialic acid to the voltage dependence of sodium channel gating: A possible electrostatic mechanism. J. Gen. Physiol. 1997, 109, 327-343. [CrossRef]

208. Ufret-Vincenty, C.A.; Baro, D.J.; Lederer, W.J.; Rockman, H.A.; Quiñones, L.E.; Santana, L.F. Role of Sodium Channel Deglycosylation in the Genesis of Cardiac Arrhythmias in Heart Failure. J. Biol. Chem. 2001, 276, 28197-28203. [CrossRef]

209. Ednie, A.R.; Bennett, E.S. Modulation of voltage-gated ion channels by sialylation. Compr. Physiol. 2012, 2, 1269-1301. [CrossRef]

210. Gu, F.; Crump, C.M.; Thomas, G. Trans-golgi network sorting. Cell. Mol. Life Sci. 2001, 58, 1067-1084. [CrossRef]

211. Ponce-Balbuena, D.; Guerrero-Serna, G.; Valdivia, C.R.; Caballero, R.; Diez-Guerra, F.J.; Jiménez-Vázquez, E.N.; Ramírez, R.J.; Monteiro Da Rocha, A.; Herron, T.J.; Campbell, K.F.; et al. Cardiac Kir2.1 and $\mathrm{Na}_{\mathrm{v}} 1.5$ Channels Traffic Together to the Sarcolemma to Control Excitability. Circ. Res. 2018, 122, 1501-1516. [CrossRef]

212. Willis, B.C.; Ponce-Balbuena, D.; Jalife, J. Protein assemblies of sodium and inward rectifier potassium channels control cardiac excitability and arrhythmogenesis. Am. J. Physiol.-Heart Circ. Physiol. 2015, 308, H1463-H1473. [CrossRef]

213. Yang, H.-Q.; Perez-Hernandez, M.; Sanchez-Alonso, J.; Shevchuk, A.; Gorelik, J.; Rothenberg, E.; Delmar, M.; Coetzee, W.A. Ankyrin-G mediates targeting of both $\mathrm{Na}^{+}$and $\mathrm{K}$ ATP channels to the rat cardiac intercalated disc. Elife 2020, 9, 1-23. [CrossRef]

214. Shy, D.; Gillet, L.; Abriel, H. Targeting the sodium channel $\mathrm{Na}_{\mathrm{v}} 1.5$ to specific membrane compartments of cardiac cells not a simple task! Circ. Res. 2014, 115, 901-903. [CrossRef]

215. Maier, S.K.G.; Westenbroek, R.E.; McCormick, K.A.; Curtis, R.; Scheuer, T.; Catterall, W.A. Distinct Subcellular Localization of Different Sodium Channel $\alpha$ and $\beta$ Subunits in Single Ventricular Myocytes from Mouse Heart. Circulation 2004, 109, $1421-1427$. [CrossRef]

216. Domínguez, J.N.; De La Rosa, Á.; Navarro, F.; Franco, D.; Aránega, A.E. Tissue distribution and subcellular localization of the cardiac sodium channel during mouse heart development. Cardiovasc. Res. 2008, 78, 45-52. [CrossRef] [PubMed] 
217. Cohen, S.A. Immunocytochemical localization of rh1 sodium channel in adult rat heart atria and ventricle: Presence in terminal intercalated disks. Circulation 1996, 94, 3083-3086. [CrossRef] [PubMed]

218. Shy, D.; Gillet, L.; Abriel, H. Cardiac sodium channel $\mathrm{Na}_{\mathrm{v}} 1.5$ distribution in myocytes via interacting proteins: The multiple pool model. Biochim. Biophys. Acta-Mol. Cell Res. 2013, 1833, 886-894. [CrossRef]

219. Peeters, U.; Scornik, F.; Riuró, H.; Pérez, G.; Komurcu-Bayrak, E.; Van Malderen, S.; Pappaert, G.; Tarradas, A.; Pagans, S.; Daneels, D.; et al. Contribution of cardiac sodium channel $\beta$-subunit variants to brugada syndrome. Circ. J. 2015, 79, 2118-2129. [CrossRef]

220. Salvage, S.C.; Rees, J.S.; McStea, A.; Hirsch, M.; Wang, L.; Tynan, C.J.; Reed, M.W.; Irons, J.R.; Butler, R.; Thompson, A.J.; et al. Supramolecular clustering of the cardiac sodium channel $\mathrm{Na}_{\mathrm{v}} 1.5$ in HEK293F cells, with and without the auxiliary $\beta 3$-subunit. FASEB J. 2020, 34, 3537-3553. [CrossRef]

221. Catterall, W.A. Voltage-gated sodium channels at 60_ structure, function and pathophysiology. J. Physiol. 2012, 590, 2577-2589. [CrossRef]

222. Chen, C.; Calhoun, J.D.; Zhang, Y.; Lopez-Santiago, L.; Zhou, N.; Davis, T.H.; Salzer, J.L.; Isom, L.L. Identification of the cysteine residue responsible for disulfide linkage of $\mathrm{Na}^{+}$channel alpha and beta2. J. Biol. Chem. 2012, 287, 39061-39069. [CrossRef]

223. Yu, F.H.; Westenbroek, R.E.; Silos-santiago, I.; Mccormick, K.A.; Lawson, D.; Ge, P.; Ferriera, H.; Lilly, J.; Distefano, P.S.; Catterall, W.A.; et al. Sodium Channel $\beta 4$, a New Disulfide-Linked Auxiliary Subunit with Similarity to $\beta 2$. J. Neurosci. 2003, 23, 7577-7585. [CrossRef] [PubMed]

224. Zhu, W.; Voelker, T.L.; Varga, Z.; Schubert, A.R.; Nerbonne, J.M.; Silva, J.R. Mechanisms of noncovalent $\beta$ subunit regulation of $\mathrm{Na}_{\mathrm{v}}$ channel gating. J. Gen. Physiol. 2017, 149, 813-831. [CrossRef] [PubMed]

225. Malhotra, J.D.; Kazen-Gillespie, K.; Hortsch, M.; Isom, L.L. Sodium channel $\beta$ subunits mediate homophilic cell adhesion and recruit ankyrin to points of cell-cell contact. J. Biol. Chem. 2000, 275, 11383-11388. [CrossRef] [PubMed]

226. Domínguez, J.N.; Navarro, F.; Franco, D.; Thompson, R.P.; Aránega, A.E. Temporal and spatial expression pattern ofh1 sodium channel subunitduring heart development. Cardiovasc. Res. 2004, 65, 842-850. [CrossRef]

227. Zimmer, T.; Biskup, C.; Bollensdorff, C.; Benndorf, K. The $\beta 1$ Subunit but not the $\beta 2$ Subunit Colocalizes with the Human Heart $\mathrm{Na}^{+}$Channel $(\mathrm{hHl})$ already within the Endoplasmic Reticulum. J. Membr. Biol. 2002, 186, 13-21. [CrossRef]

228. Mercier, A.; Clement, R.; Harnois, T.; Bourmeyster, N.; Faivre, J.F.; Findlay, I.; Chahine, M.; Bois, P.; Chatelier, A. The $\beta 1-S u b u n i t$ of $\mathrm{Na}_{\mathrm{v}} 1.5$ Cardiac Sodium Channel Is Required for a Dominant Negative Effect through $\alpha-\alpha$ Interaction. PLoS ONE 2012, 7, e48690.

229. Dulsat, G.; Palomeras, S.; Cortada, E.; Riuró, H.; Brugada, R.; Vergés, M. Trafficking and localisation to the plasma membrane of $\mathrm{Na}$ v 1.5 promoted by the $\beta 2$ subunit is defective due to a $\beta 2$ mutation associated with Brugada syndrome. Biol. Cell 2017, 109, 273-291. [CrossRef]

230. Namadurai, S.; Balasuriya, D.; Rajappa, R.; Wiemhöfer, M.; Stott, K.; Klingauf, J.; Edwardson, J.M.; Chirgadze, D.Y.; Jackson, A.P. Crystal structure and molecular imaging of the Nav channel $\beta 3$ subunit indicates a trimeric assembly. J. Biol. Chem. 2014, 289, 10797-10811. [CrossRef]

231. Medeiros-Domingo, A.; Kaku, T.; Tester, D.J.; Iturralde-Torres, P.; Itty, A.; Ye, B.; Valdivia, C.; Ueda, K.; Canizales-Quinteros, S.; Tusié-Luna, M.T.; et al. SCN4B-Encoded Sodium Channel $\beta 4$ Subunit in Congenital Long-QT Syndrome. Circulation 2007, 116, 134-142. [CrossRef] [PubMed]

232. Watanabe, H.; Koopmann, T.T.; Le Scouarnec, S.; Yang, T.; Ingram, C.R.; Schott, J.-J.; Demolombe, S.; Probst, V.; Anselme, F.; Escande, D.; et al. Sodium channel $\beta 1$ subunit mutations associated with Brugada syndrome and cardiac conduction disease in humans. J. Clin. Investig. 2008, 118, 2260-2268. [CrossRef]

233. Wilde, A.A.M.; Brugada, R. Phenotypical manifestations of mutations in the genes encoding subunits of the cardiac sodium channel. Circ. Res. 2011, 108, 884-897. [CrossRef] [PubMed]

234. O'Malley, H.A.; Isom, L.L. Sodium channel $\beta$ subunits: Emerging targets in channelopathies. Annu. Rev. Physiol. 2015, 77, 481-504. [CrossRef] [PubMed]

235. Qu, Y.; Curtis, R.; Lawson, D.; Gilbride, K.; Ge, P.; DiStefano, P.S.; Silos-Santiago, I.; Catterall, W.A.; Scheuer, T. Differential Modulation of Sodium Channel Gating and Persistent Sodium Currents by the $\beta 1, \beta 2$, and $\beta 3$ Subunits. Mol. Cell. Neurosci. 2001, 18, 570-580. [CrossRef] [PubMed]

236. Morgan, K.; Stevens, E.B.; Shah, B.; Cox, P.J.; Dixon, A.K.; Lee, K.; Pinnock, R.D.; Hughes, J.; Richardson, P.J.; Mizuguchi, K.; et al. B3: An additional auxiliary subunit of the voltage-sensitive sodium channel that modulates channel gating with distinct kinetics. Proc. Natl. Acad. Sci. USA 2000, 97, 2308-2313. [CrossRef]

237. Delmar, M. Connexin 43 regulates sodium current; Ankyrin-G modulates gap junctions: The intercalated disc exchanger. Cardiovasc. Res. 2012, 93, 220-222. [CrossRef]

238. Abriel, H.; Rougier, J.S.; Jalife, J. Ion Channel Macromolecular Complexes in Cardiomyocytes: Roles in Sudden Cardiac Death. Circ. Res. 2015, 116, 1971-1988. [CrossRef]

239. Godreau, D.; Vranckx, R.; Maguy, A.; Goyenvalle, C.; Hatem, S.N. Different Isoforms of Synapse-associated Protein, SAP97, Are Expressed in the Heart and Have Distinct Effects on the Voltage-gated K ${ }^{+}$Channel Kv1.5. J. Biol. Chem. 2003, 278, 47046-47052. [CrossRef]

240. Milstein, M.L.; Musa, H.; Balbuena, D.P.; Anumonwo, J.M.B.; Auerbach, D.S.; Furspan, P.B.; Hou, L.; Hu, B.; Schumacher, S.M.; Vaidyanathan, R.; et al. Dynamic reciprocity of sodium and potassium channel expression in a macromolecular complex controls cardiac excitability and arrhythmia. Proc. Natl. Acad. Sci. USA 2012, 109, E2134-E2143. [CrossRef] 
241. Petitprez, S.; Zmoos, A.F.; Ogrodnik, J.; Balse, E.; Raad, N.; El-Haou, S.; Albesa, M.; Bittihn, P.; Luther, S.; Lehnart, S.E.; et al. SAP97 and dystrophin macromolecular complexes determine two pools of cardiac sodium channels $\mathrm{Na}_{\mathrm{v}} 1.5$ in cardiomyocytes. Circ. Res. 2011, 108, 294-304. [CrossRef] [PubMed]

242. Gillet, L.; Rougier, J.S.; Shy, D.; Sonntag, S.; Mougenot, N.; Essers, M.; Shmerling, D.; Balse, E.; Hatem, S.N.; Abriel, H. Cardiacspecific ablation of synapse-associated protein SAP97 in mice decreases potassium currents but not sodium current. Heart Rhythm 2015, 12, 181-192. [CrossRef] [PubMed]

243. Mohler, P.J. Editorial: Sodium channel traffic on the cardiac microtubule highway. Cardiovasc. Res. 2010, 85, 645-646. [CrossRef] [PubMed]

244. Agullo-Pascual, E.; Lin, X.; Leo-Macias, A.; Zhang, M.; Liang, F.; Li, Z.; Pfenniger, A.; Bkemeier, I.L.; Keegan, S.; Fenyo, D.; et al. Super-resolution imaging reveals that loss of theC-terminus of connexin 43 limits microtubuleplus-end capture and $\mathrm{Na}_{\mathrm{v}} 1.5$ localization at theintercalated disc. Cardiovasc. Res. 2014, 104, 371-381. [CrossRef] [PubMed]

245. Marchal, G.A.; Jouni, M.; Chiang, D.Y.; Pérez-Hernández, M.; Podliesna, S.; Yu, N.; Casini, S.; Potet, F.; Veerman, C.C.; Klerk, M.; et al. Targeting the Microtubule EB1-CLASP2 Complex Modulates Na 1.5 at Intercalated Discs. Circ. Res. 2021, 129, $349-365$. [CrossRef] [PubMed]

246. Mimori-Kiyosue, Y.; Grigoriev, I.; Lansbergen, G.; Sasaki, H.; Matsui, C.; Severin, F.; Galjart, N.; Grosveld, F.; Vorobjev, I.; Tsukita, S.; et al. CLASP1 and CLASP2 bind to EB1 and regulate microtubule plus-end dynamics at the cell cortex. J. Cell Biol. 2005, 168, 141-153. [CrossRef]

247. Desplantez, T. Cardiac Cx43, Cx40 and Cx45 co-assembling: Involvement of connexins epitopes in formation of hemichannels and Gap junction channels. BMC Cell Biol. 2017, 18,1-13. [CrossRef]

248. Hunter, A.W.; Barker, R.J.; Zhu, C.; Gourdie, R.G. Zonula occludens-1 alters connexin43 gap junction size and organization by influencing channel accretion. Mol. Biol. Cell 2005, 16, 5686-5698. [CrossRef]

249. Rhett, J.M.; Ongstad, E.L.; Jourdan, J.; Gourdie, R.G. Cx43 Associates with $\mathrm{Na}_{\mathrm{v}} 1.5$ in the Cardiomyocyte Perinexus. J. Membr. Biol. 2012, 245, 411-422.

250. Noorman, M.; Hakim, S.; Kessler, E.; Groeneweg, J.; Cox, M.G.P.J.; Asimaki, A.; van Rijen, H.V.M.; van Stuijvenberg, L.; Chkourko, H.; van der Heyden, M.A.G.; et al. Remodeling of the cardiac sodium channel, Connexin 43 andPlakoglobin at the intercalated disk in patients witharrhythmogenic cardiomyopathy. Heart Rhythm 2013, 10, 412-419. [CrossRef] [PubMed]

251. Rhett, J.M.; Veeraraghavan, R.; Poelzing, S.; Gourdie, R.G. The perinexus: Sign-post on the path to a new model of cardiac conduction? Trends Cardiovasc. Med. 2013, 23, 222-228. [CrossRef]

252. Cunha, S.R.; Mohler, P.J. Cardiac ankyrins: Essential components for development and maintenance of excitable membrane domains in heart. Cardiovasc. Res. 2006, 71, 22-29. [CrossRef]

253. Hashemi, S.M.; Hund, T.J.; Mohler, P.J. Cardiac ankyrins in health and disease. J. Mol. Cell. Cardiol. 2009, 47, 203-209. [CrossRef]

254. Makara, M.A.; Curran, J.; Little, S.C.; Musa, H.; Polina, I.; Smith, S.A.; Wright, P.J.; Unudurthi, S.D.; Snyder, J.; Bennett, V.; et al. Ankyrin-G Coordinates Intercalated Disc Signaling Platform to Regulate Cardiac Excitability In Vivo. Circ Res. 2014, 115, 929-938. [CrossRef] [PubMed]

255. Hund, T.J.; Koval, O.M.; Li, J.; Wright, P.J.; Qian, L.; Snyder, J.S.; Gudmundsson, H.; Kline, C.F.; Davidson, N.P.; Cardona, N.; et al. A $\beta$ IV -spectrin/CaMKII signaling complex is essential for membrane excitability in mice. J. Clin. Investig. 2010, 120, 3508-3519. [CrossRef] [PubMed]

256. Sato, P.Y.; Coombs, W.; Lin, X.; Nekrasova, O.; Green, K.J.; Isom, L.L.; Taffet, S.M.; Delmar, M. Interactions Between Ankyrin-G, Plakophilin-2, and Connexin43 at the Cardiac Intercalated Disc. Circ Res. 2011, 109, 193-201. [CrossRef]

257. Makara, M.A.; Curran, J.; Lubbers, E.R.; Murphy, N.P.; Little, S.C.; Musa, H.; Smith, S.A.; Unudurthi, S.D.; Rajaram, M.V.S.; Janssen, P.M.L.; et al. Novel Mechanistic Roles for Ankyrin-G in Cardiac Remodeling and Heart Failure. JACC Basic Transl. Sci. 2018, 3, 675-689. [CrossRef] [PubMed]

258. Mohler, P.J.; Rivolta, I.; Napolitano, C.; Lemaillet, G.; Lambert, S.; Priori, S.G.; Bennett, V. Na 1.5 E1053K mutation causing Brugada syndrome blocks binding to ankyrin-G and expression of $\mathrm{Na}_{\mathrm{v}} 1.5$ on the surface of cardiomyocytes. Proc. Natl. Acad. Sci. USA 2004, 101, 17533-17538. [CrossRef]

259. Cavus, O.; Williams, J.; Musa, H.; el Refaey, M.; Gratz, D.; Shaheen, R.; Schwieterman, N.A.; Koenig, S.; Antwi-Boasiako, S.; Young, L.J.; et al. Giant ankyrin-G regulates cardiac function. J. Biol. Chem. 2021, 296, 1-13. [CrossRef]

260. Cerrone, M.; Delmar, M. Desmosomes and the sodium channel complex: Implications for arrhythmogenic cardiomyopathy and Brugada syndrome. Trends Cardiovasc. Med. 2014, 24, 184-190. [CrossRef]

261. Cerrone, M.; Lin, X.; Zhang, M.; Agullo-Pascual, E.; Pfenniger, A.; Chkourko Gusky, H.; Novelli, V.; Kim, C.; Tirasawadichai, T.; Judge, D.P.; et al. Missense mutations in plakophilin-2 cause sodium current deficit and associate with a brugada syndrome phenotype. Circulation 2014, 129, 1092-1103. [CrossRef]

262. Cerrone, M.; Lin, X.; Zhang, M.; Agullo-Pascual, E.; Pfenniger, A.; Chkourko Gusky, H.; Novelli, V.; Kim, C.; Tirasawadischai, T.; Judge, D.P.; et al. Missense Mutations in Plakophilin-2 Can Cause Brugada Syndrome Phenotype By Decreasing Sodium Current and $\mathrm{Na}_{\mathrm{v}}$ 1.5 Membrane Localization. Heart Rhythm 2013, 10, 1743. [CrossRef]

263. Sato, P.Y.; Musa, H.; Coombs, W.; Guerrero-Serna, G.; Patiño, G.A.; Taffet, S.M.; Isom, L.L.; Delmar, M. Loss of plakophilin-2 expression leads to decreased sodium current and slower conduction velocity in cultured cardiac myocytes. Circ. Res. 2009, 105, 523-526. [CrossRef] 
264. Kim, C.; Wong, J.; Wen, J.; Wang, S.; Wang, C.; Spiering, S.; Kan, N.G.; Forcales, S.; Puri, P.L.; Leone, T.C.; et al. Studying arrhythmogenic right ventricular dysplasia with patient-specific iPSCs. Nature 2013, 494, 105-110. [CrossRef]

265. Rizzo, S.; Lodder, E.M.; Verkerk, A.O.; Wolswinkel, R.; Beekman, L.; Pilichou, K.; Basso, C.; Remme, C.A.; Thiene, G.; Bezzina, C.R. Intercalated disc abnormalities, reduced $\mathrm{Na}^{+}$current density, and conduction slowing in desmoglein-2 mutant mice prior to cardiomyopathic changes. Cardiovasc. Res. 2012, 95, 409-418. [CrossRef]

266. Zhang, Q.; Deng, C.; Rao, F.; Modi, R.M.; Zhu, J.; Liu, X.; Mai, L.; Tan, H.; Yu, X.; Lin, Q.; et al. Silencing of desmoplakin decreases connexin43/ $\mathrm{Na}_{\mathrm{v}} 1.5$ expression and sodium current in HL-1 cardiomyocytes. Mol. Med. Rep. 2013, 8, 780-786. [CrossRef]

267. Cunha, S.R.; Mohler, P.J. Ankyrin protein networks in membrane formation and stabilization. J. Cell. Mol. Med. 2009, 13, 4364-4376. [CrossRef] [PubMed]

268. Nassal, D.; Yu, J.; Min, D.; Lane, C.; Shaheen, R.; Gratz, D.; Hund, T.J. Regulation of cardiac conduction and arrhythmias by ankyrin/spectrin-based macromolecular complexes. J. Cardiovasc. Dev. Dis. 2021, 8, 48. [CrossRef] [PubMed]

269. Bennett, V.; Chen, L. Ankyrins and cellular targeting of diverse membrane proteins to physiological sites. Curr. Opin. Cell Biol. 2001, 13, 61-67. [CrossRef]

270. Glynn, P.; Musa, H.; Wu, X.; Unudurthi, S.D.; Little, S.; Qian, L.; Wright, P.J.; Radwanski, P.B.; Gyorke, S.; Mohler, P.J.; et al. Voltage-Gated Sodium Channel Phosphorylation at Ser571 Regulates Late Current, Arrhythmia, and Cardiac Function in Vivo. Circulation 2015, 132, 567-577. [CrossRef]

271. Greer-Short, A.; Musa, H.; Alsina, K.M.; Ni, L.; Word, T.A.; Reynolds, J.O.; Gratz, D.; Lane, C.; El-Refaey, M.; Unudurthi, S.; et al. Calmodulin kinase II regulates atrial myocyte late sodium current, calcium handling, and atrial arrhythmia. Heart Rhythm 2020, 17, 503-511. [CrossRef]

272. Marsman, R.F.; Bezzina, C.R.; Freiberg, F.; Verkerk, A.O.; Adriaens, M.E.; Podliesna, S.; Chen, C.; Purfürst, B.; Spallek, B.; Koopmann, T.T.; et al. Coxsackie and adenovirus receptor (CAR) is a modifier of cardiac conduction and arrhythmia vulnerability in the setting of myocardial ischemia. J. Am. Coll. Cardiol. 2015, 63, 549-559. [CrossRef] [PubMed]

273. Noutsias, M.; Fechner, H.; De Jonge, H.; Wang, X.; Dekkers, D.; Houtsmuller, A.B.; Pauschinger, M.; Bergelson, J.; Warraich, R.; Yacoub, M.; et al. Human Coxsackie-Adenovirus Receptor Is Colocalized With Integrins avb3 and avb5 on the Cardiomyocyte Sarcolemma and Upregulated in Dilated Cardiomyopathy Implications for Cardiotropic Viral Infections. Heart 2001, 104, 275-280.

274. Clatot, J.; Ziyadeh-Isleem, A.; Maugenre, S.; Denjoy, I.; Liu, H.; Dilanian, G.; Hatem, S.N.; Deschenes, I.; Coulombe, A.; Guicheney, P.; et al. Dominant-negative effect of $S C N 5 A$ N-terminal mutations through the interaction of $\mathrm{Na}_{\mathrm{v}} 1.5$ alpha subunits. Cardiovasc. Res. 2012, 96, 53-56. [CrossRef]

275. Clatot, J.; Hoshi, M.; Wan, X.; Liu, H.; Jain, A.; Shinlapawittayatorn, K.; Marionneau, C.; Ficker, E.; Ha, T.; Deschênes, I. Voltage-gated sodium channels assemble and gate as dimers. Nat. Commun. 2017, 8, 2077. [CrossRef]

276. Allouis, M.; Le Bouffant, F.; Wilders, R.; Péroz, D.; Schott, J.J.; Noireaud, J.; Le Marec, H.; Mérot, J.; Escande, D.; Baró, I. 14-3-3 Is a regulator of the cardiac voltage-gated sodium channel $\mathrm{Na}_{\mathrm{v}}$ 1.5. Circ. Res. 2006, 98, 1538-1546. [CrossRef]

277. Rougier, J.S.; Essers, M.C.; Gillet, L.; Guichard, S.; Sonntag, S.; Shmerling, D.; Abriel, H. A Distinct Pool of Na 1.5 Channels at the Lateral Membrane of Murine Ventricular Cardiomyocytes. Front. Physiol. 2019, 10, 1-20. [CrossRef]

278. Gee, S.H.; Madhavan, R.; Levinson, S.R.; Caldwell, J.H.; Sealock, R.; Froehner, S.C. Interaction of muscle and brain sodium channels with multiple members of the syntrophin family of dystrophin-associated proteins. J. Neurosci. 1998, 18, $128-137$. [CrossRef]

279. Ou, Y.; Strege, P.; Miller, S.M.; Makielski, J.; Ackerman, M.; Gibbons, S.J.; Farrugia, G. Syntrophin $\gamma 2$ regulates SCN5A gating by a PDZ domain-mediated interaction. J. Biol. Chem. 2003, 278, 1915-1923. [CrossRef] [PubMed]

280. Schultz, J.; Hoffmuller, U.; Krause, G.; Ashurst, J.; Macias, M.J.; Schmieder, P.; Schneider-Mergener, J.; Oschkinat, H. Specific interactions between the syntrophin PDZ domain and voltagegated sodium channels. Nat. Struct. Biol. 1998, 5, 19-24. [CrossRef] [PubMed]

281. Matamoros, M.; Perez-Hernandez, M.; Guerrero-Serna, G.; Amoros, I.; Barana, A.; Nunez, M.; Ponce-Balbuena, D.; Sacristan, S.; Gomez, R.; Tamargo, J.; et al. $\mathrm{Na}_{\mathrm{v}} 1.5 \mathrm{~N}$-terminal domain binding to alpha1 syntrophin incraeses membrane density of human Kir2.1 Kir2.2 and $\mathrm{Na}_{\mathrm{v}}$ 1.5. Cardiovasc. Res. 2016, 110, 279-290. [CrossRef] [PubMed]

282. Pérez-hernández, M.; Caballero, R.; Delpón, E.; Pérez-hernández, M.; Matamoros, M.; Alfayate, S.; Nieto-marín, P.; Utrilla, R.G.; Tinaquero, D.; De Andrés, R.; et al. channels can trap cardiac Kir2.1/2.2 channels. JCI Insights 2018, 3, e96291. [CrossRef] [PubMed]

283. Eichel, C.A.; Beuriot, A.; Chevalier, M.Y.E.; Rougier, J.S.; Louault, F.; Dilanian, G.; Amour, J.; Coulombe, A.; Abriel, H.; Hatem, S.N.; et al. Lateral Membrane-Specific MAGUK CASK Down-Regulates $\mathrm{Na}_{\mathrm{v}} 1.5$ Channel in Cardiac Myocytes. Circ. Res. 2016, 119, 544-556. [CrossRef] [PubMed]

284. Ziane, R.; Huang, H.; Moghadaszadeh, B.; Beggs, A.H.; Levesque, G.; Chahine, M. Cell membrane expression of cardiac sodium channel $\mathrm{Na}_{\mathrm{v}} 1.5$ is modulated by $\alpha$-actinin-2 interaction. Biochemistry 2010, 49, 166-178. [CrossRef] [PubMed]

285. Mazzone, A.; Strege, P.R.; Tester, D.J.; Bernard, C.E.; Faulkner, G.; De Giorgio, R.; Makielski, J.C.; Stanghellini, V.; Gibbons, S.J.; Ackerman, M.J.; et al. A Mutation in Telethonin Alters Na 1.5 Function. J. Biol. Chem. 2008, 283, 16537-16544. [CrossRef]

286. Turker, I.; Makiyama, T.; Ueyama, T.; Shimizu, A.; Yamakawa, M.; Chen, P.S.; Vatta, M.; Horie, M.; Ai, T. Telethonin Variants Found in Brugada Syndrome, J-Wave Pattern ECG, and ARVC Reduce Peak Na 1.5 Currents in HEK-293 Cells. PACE-Pacing Clin. Electrophysiol. 2020, 43, 838-846. [CrossRef] 
287. Goldfarb, M. Fibroblast growth factor homologous factors evolution, structure, and function. Cytokine Growth Factor Rev. 2005, 16, 215-220. [CrossRef]

288. Rush, A.M.; Wittmack, E.K.; Tyrrell, L.; Black, J.A.; Dib-hajj, S.D.; Waxman, S.G. Differential modulation of sodium channel Na 1.6 by two members of the fibroblast growth factor homologous factor 2 subfamily. Eur. J. Neurosci. 2006, 23, 2551-2562. [CrossRef]

289. Liu, C.; Dib-Hajj, S.D.; Renganathan, M.; Cummins, T.R.; Waxman, S.G. Modulation of the cardiac sodium channel Na 1.5 by fibroblast growth factor homologous factor 1B. J. Biol. Chem. 2003, 278, 1029-1036. [CrossRef]

290. Wang, C.; Hennessey, J.A.; Kirkton, R.D.; Wang, C.; Graham, V.; Puranam, R.S.; Rosenberg, P.B.; Bursac, N.; Pitt, G.S. Fibroblast Growth Factor Homologous Factor 13 Regulates $\mathrm{Na}^{+}$Channels and Conduction Velocity in Murine Hearts. Circ. Res. 2011, 109, 775-782. [CrossRef] [PubMed]

291. Wang, C.; Wang, C.; Hoch, E.G.; Pitt, G.S. Identification of Novel Interaction Sites that Determine Specificity between Fibroblast Growth Factor Homologous Factors and Voltage-gated Sodium Channels. J. Biol. Chem. 2011, 286, 24253-24263. [CrossRef]

292. Yang, J.; Wang, Z.; Sinden, D.S.; Wang, X.; Shan, B.; Yu, X.; Zhang, H.; Pitt, G.S.; Wang, C. FGF13 modulates the gating properties of the cardiac sodium channel $\mathrm{Na}_{\mathrm{v}} 1.5$ in an isoform-specific maner. Channels 2016, 10, 410-420. [CrossRef]

293. Lou, J.Y.; Laezza, F.; Gerber, B.R.; Xiao, M.; Yamada, K.A.; Hartmann, H.; Craig, A.M.; Nerbonne, J.M.; Ornitz, D.M. Fibroblast growth factor 14 is an intracellular modulator of voltage-gated sodium channels. J. Physiol. 2005, 569, 179-193. [CrossRef] [PubMed]

294. Mohler, P.J.; Splawski, I.; Napolitano, C.; Bottelli, G.; Sharpe, L.; Timothy, K.; Priori, S.G.; Keating, M.T.; Bennett, V. A cardiac arrhythmia syndrome caused by loss of ankyrin-B function. Proc. Natl. Acad. Sci. USA 2004, 101, 9137-9142. [CrossRef]

295. Wang, C.; Chung, B.C.; Yan, H.; Wang, H.G.; Lee, S.Y.; Pitt, G.S. Structural analyses of $\mathrm{Ca}^{2+} / \mathrm{CaM}$ interaction with NaV channel C-termini reveal mechanisms of calcium-dependent regulation. Nat. Commun. 2014, 5, 4896. [CrossRef]

296. Urbauer, J.L. Direct Sodium Channel Regulation by Calmodulin. Structure 2018, 26, 677-678. [CrossRef] [PubMed]

297. Kang, P.W.; Chakouri, N.; Diaz, J.; Tomaselli, G.F.; Yue, D.T.; Ben-Johny, M. Elementary mechanisms of calmodulin regulation of $\mathrm{Na}_{\mathrm{v}} 1.5$ producing divergent arrhythmogenic phenotypes. Proc. Natl. Acad. Sci. USA 2021, 118, e2025085118. [CrossRef] [PubMed]

298. Turnow, K.; Metzner, K.; Cotella, D.; Morales, M.J.; Schaefer, M.; Christ, T.; Ravens, U.; Wettwer, E.; Kämmerer, S. Interaction of DPP10a with Kv4.3 channel complex results in a sustained current component of human transient outward current Ito. Basic Res. Cardiol. 2015, 110, 5. [CrossRef]

299. Belau, F.; Metzner, K.; Christ, T.; Ravens, U.; Schaefer, M.; Künzel, S.; Li, W.; Wettwer, E.; Dobrev, D.; El-Armouche, A.; et al. DPP10 is a new regulator of $\mathrm{Na}_{\mathrm{v}} 1.5$ channels in human heart. Int. J. Cardiol. 2019, 284, 68-73. [CrossRef]

300. Yarbrough, T.L.; Lu, T.; Lee, H.-C.; Shibata, E.F. Localization of Cardiac Sodium Channels in Caveolin-Rich Membrane Domains. Circ. Res. 2002, 90, 443-449. [CrossRef]

301. Balijepalli, R.C.; Kamp, T.J. Caveolae, Ion Channels and Cardiac Arrhythmias. Prog. Biophys. Mol. Biol. 2008, 98, 149-160. [CrossRef] [PubMed]

302. Xiao, Y.F.; Kang, J.X.; Morgan, J.P.; Leaf, A. Blocking effects of polyunsaturated fatty acids on $\mathrm{Na}^{+}$channels of neonatal rat ventricular myocytes. Proc. Natl. Acad. Sci. USA 1995, 92, 11000-11004. [CrossRef] [PubMed]

303. Kang, J.X.; Xiao, Y.F.; Leaf, A. Free, long-chain, polyunsaturated fatty acids reduce membrane electrical excitability in neonatal rat cardiac myocytes. Proc. Natl. Acad. Sci. USA 1995, 92, 3997-4001. [CrossRef]

304. Shibata, E.F.; Brown, T.L.Y.; Washburn, Z.W.; Bai, J.; Revak, T.J.; Butters, C.A. Autonomic Regulation of Voltage-Gated Cardiac Ion Channels. J. Cardiovasc. Electrophysiol. 2006, 17, 34-42. [CrossRef]

305. Vatta, M.; Ackerman, M.J.; Ye, B.; Makielski, J.C.; Ughanze, E.E.; Taylor, E.W.; Tester, D.J.; Balijepalli, R.C.; Foell, J.D.; Li, Z.; et al Mutant Caveolin-3 Induces Persistent Late Sodium Current and Is Associated With Long-QT Syndrome. Circulation 2006, 114, 2104-2112. [CrossRef]

306. Vaidyanathan, R.; Reilly, L.; Eckhardt, L.L. Caveolin-3 Microdomain: Arrhythmia Implications for Potassium Inward Rectifier and Cardiac Sodium Channel. Front. Physiol. 2018, 9, 1-8. [CrossRef] [PubMed]

307. Ehrlich, J.R. Taking ion channel degradation to heart. Cardiovasc. Res. 2007, 74, 6-7. [CrossRef]

308. Abriel, H.; Staub, O. Ubiquitylation of ion channels. Physiology 2005, 20, 398-407. [CrossRef] [PubMed]

309. Liu, X.; Chen, Z.; Han, Z.; Liu, Y.; Wu, X.; Peng, Y.; Di, W.; Lan, R.; Sun, B.; Xu, B.; et al. AMPK-mediated degradation of Na 1.5 through autophagy. FASEB J. 2019, 33, 5366-5376. [CrossRef] [PubMed]

310. Van Bemmelen, M.X.; Rougier, J.S.; Gavillet, B.; Apothéloz, F.; Daidié, D.; Tateyama, M.; Rivolta, I.; Thomas, M.A.; Kass, R.S.; Staub, O.; et al. Cardiac voltage-gated sodium channel $\mathrm{Na}_{\mathrm{v}} 1.5$ is regulated by Nedd4-2 mediated ubiquitination. Circ. Res. 2004, 95, 284-291. [CrossRef]

311. Rougier, J.S.; Van Bemmelen, M.X.; Bruce, M.C.; Jespersen, T.; Gavillet, B.; Apothéloz, F.; Cordonier, S.; Staub, O.; Rotin, D.; Abriel, H. Molecular determinants of voltage-gated sodium channel regulation by the Nedd4/Nedd4-like proteins. Am. J. Physiol.-Cell Physiol. 2005, 288, 692-701. [CrossRef] [PubMed]

312. Huang, Y.; Wang, Z.; Liu, Y.; Xiong, H.; Zhao, Y.; Wu, L.; Yuan, C.; Wang, L.; Hou, Y.; Yu, G.; et al. $\alpha$ B-crystallin interacts with $\mathrm{Na}_{\mathrm{v}} 1.5$ and regulates ubiquitination and internalization of cell surface $\mathrm{Na}_{\mathrm{v}}$ 1.5. J. Biol. Chem. 2016, 291, 11030-11041. [CrossRef]

313. Boehmer, C.; Wilhelm, V.; Palmada, M.; Wallisch, S.; Henke, G.; Brinkmeier, H.; Cohen, P.; Pieske, B.; Lang, F. Serum and glucocorticoid inducible kinases in the regulation of the cardiac sodium channel SCN5A. Cardiovasc. Res. 2003, 57, 1079-1084. [CrossRef] 
314. Tang, B.; Hu, Y.; Wang, Z.; Cheng, C.; Wang, P.; Liang, L.; Xiong, H.; Luo, C.; Xu, C.; Chen, Q.; et al. UBC9 regulates cardiac sodium channel $\mathrm{Na}_{\mathrm{v}} 1.5$ ubiquitination, degradation and sodium current density. J. Mol. Cell Cardiol. 2019, 129, 79-91. [CrossRef] [PubMed]

315. Liu, X.; Ge, J.; Chen, C.; Shen, Y.; Xie, J.; Zhu, X.; Liu, M.; Hu, J.; Chen, L.; Guo, L.; et al. FAT10 protects against ischemia-induced ventricular arrhythmia by decreasing Nedd4-2_Na $\mathrm{Na}_{\mathrm{v}} 1.5$ complex formation. Cell Death Dis. 2021, 12, 1-12.

316. Bhalla, V.; Oyster, N.M.; Fitch, A.C.; Wijngaarden, M.A.; Neumann, D.; Schlattner, U.; Pearce, D.; Hallows, K.R. AMP-activated kinase inhibits the epithelial $\mathrm{Na}^{+}$channel through functional regulation of the ubiquitin ligase Nedd4-2. J. Biol. Chem. 2006, 281, 26159-26169. [CrossRef] [PubMed]

317. Tadros, R.; Ton, A.T.; Fiset, C.; Nattel, S. Sex differences in cardiac electrophysiology and clinical arrhythmias: Epidemiology, therapeutics, and mechanisms. Can. J. Cardiol. 2014, 30, 783-792. [CrossRef]

318. Costa, S.; Saguner, A.M.; Gasperetti, A.; Akdis, D.; Brunckhorst, C.; Duru, F. The Link Between Sex Hormones and Susceptibility to Cardiac Arrhythmias: From Molecular Basis to Clinical Implications. Front. Cardiovasc. Med. 2021, 8, 85. [CrossRef]

319. Gaborit, N.; Varro, A.; Le Bouter, S.; Szuts, V.; Escande, D.; Nattel, S.; Demolombe, S. Gender-related differences in ion-channel and transporter subunit expression in non-diseased human hearts. J. Mol. Cell. Cardiol. 2010, 49, 639-646. [CrossRef]

320. Furukawa, T.; Kurokawa, J. Regulation of cardiac ion channels via non-genomic action of sex steroid hormones: Implication for the gender difference in cardiac arrhythmias. Pharmacol. Ther. 2007, 115, 106-115. [CrossRef]

321. Clemens Moller, R.N. Effects of estradiol on cardiac ion channel currents. Eur. J. Pharmacol. 2006, 532, 44-49. [CrossRef]

322. Yang, G.; Liu, J.; Wang, Y.; Du, Y.; Ma, A.; Wang, T. Lack of influence of sex hormones on Brugada syndrome-associated mutant $\mathrm{Na}_{\mathrm{v}} 1.5$ sodium channel. J. Electrocardiol. 2019, 52, 82-87. [CrossRef] [PubMed]

323. Peto, K.; Miko, I.; Ba, T.; To, I.B. Effects of sex hormones on ECG parameters and expression of cardiac ion channels in dogs. Acta Physiol. 2006, 188, 163-171. [CrossRef]

324. Hu, X.; Fu, L.; Zhao, M.; Wang, D.; Zhang, H.; Gong, Z.; Ma, T.; Zhang, Y.; Machuki, J.; Pan, X.; et al. Sex hormones ameliorated sodium channel dysfunction induced by $\beta$-adrenergic overstimulation: The role of estrogen and $G$ protein-coupled estrogen receptor. Authorea Prepr. 2020, 1-12. [CrossRef]

325. Mangold, K.E.; Brumback, B.D.; Angsutararux, P.; Voelker, T.L.; Zhu, W.; Kang, P.W.; Moreno, J.D.; Silva, J.R. Mechanisms and models of cardiac sodium channel inactivation. Channels 2017, 11, 517-533. [CrossRef] [PubMed]

326. Nassal, M.M.J.; Wan, X.; Dale, Z.; Deschênes, I.; Wilson, L.D.; Piktel, J.S. Mild hypothermia preserves myocardial conduction during ischemia by maintaining gap junction intracellular communication and $\mathrm{Na}^{+}$channel function. Am. J. Physiol. Heart Circ. Physiol. 2021, 312, 886-895. [CrossRef]

327. Porres, J.M.; Brugada, J.; Urbistondo, V.; García, F.; Reviejo, K.; Marco, P. Fever unmasking the Brugada syndrome. Pacing Clin. Electrophysiol. 2002, 25, 1646-1648. [CrossRef] [PubMed]

328. Abdelsayed, M.; Peters, C.H.; Ruben, P.C. Differential thermosensitivity in mixed syndrome cardiac sodium channel mutants. J. Physiol. 2015, 593, 4201-4223. [CrossRef]

329. Dumaine, R.; Towbin, J.A.; Brugada, P.; Vatta, M.; Nesterenko, D.V.; Nesterenko, V.V.; Brugada, J.; Brugada, R.; Antzelevitch, C. Ionic mechanisms responsible for the electrocardiographic phenotype of the Brugada syndrome are temperature dependent. Circ. Res. 1999, 85, 803-809. [CrossRef]

330. Peters, C.H.; Abdelsayed, M.; Ruben, P.C. Triggers for arrhythmogenesis in the Brugada and long QT 3 syndromes. Prog. Biophys. Mol. Biol. 2016, 120, 77-88. [CrossRef]

331. Kazutaka Gima and Yoram Rudy Ionic current basis of electrocardiographic waveforms: A model study. Circ. Res. 2007, 90, 889-896.

332. Park, D.S.; Shekhar, A.; Marra, C.; Lin, X.; Vasquez, C.; Solinas, S.; Kelley, K.; Morley, G.; Goldfarb, M.; Fishman, G.I. Fhf2 gene deletion causes temperature-sensitive cardiac conduction failure. Nat. Commun. 2016, 7, 1-10. [CrossRef]

333. Jones, D.K.; Peters, C.H.; Tolhurst, S.A.; Claydon, T.W.; Ruben, P.C. Extracellular proton modulation of the cardiac voltage-gated sodium channel, $\mathrm{Na}_{\mathrm{v}} 1.5$. Biophys. J. 2011, 101, 2147-2156. [CrossRef]

334. Jones, D.K.; Claydon, T.W.; Ruben, P.C. Extracellular protons inhibit charge immobilization in the cardiac voltage-gated sodium channel. Biophys. J. 2013, 105, 101-107. [CrossRef]

335. Jones, D.K.; Peters, C.H.; Allard, C.R.; Claydon, T.W.; Ruben, P.C. Proton Sensors in the Pore Domain of the Cardiac Voltage-gated Sodium Channel. J. Biol. Chem. 2013, 288, 4782-4791. [CrossRef] [PubMed]

336. Wang, Q.; Shen, J.; Li, Z.; Timothy, K.; Vincent, G.M.; Priori, S.G.; Schwartz, P.J.; Keating, M.T. Cardiac sodium channel mutations in patients with long QT syndrome, an inherited cardiac arrhythmia. Hum. Mol. Genet. 1995, 4, 1603-1607. [CrossRef]

337. Wang, D.W.; Yazawa, K.; George, A.L.; Bennett, P.B. Characterization of human cardiac $\mathrm{Na}^{+}$channel mutations in the congenital long QT syndrome. Proc. Natl. Acad. Sci. USA 1996, 93, 13200-13205. [CrossRef] [PubMed]

338. Wilde, A.A.M.; Amin, A.S. Clinical Spectrum of SCN5A Mutations. JACC Clin. Electrophysiol. 2018, 4, 569-579. [CrossRef]

339. Tester, D.J.; Ackerman, M.J. Genetics of Long QT Syndrome. Methodist Debakey Cardiovasc. J. 2014, 10, 29. [CrossRef] [PubMed]

340. Pérez-Riera, A.R.; Barbosa-Barros, R.; Daminello Raimundo, R.; da Costa de Rezende Barbosa, M.P.; Esposito Sorpreso, I.C.; de Abreu, L.C. The congenital long QT syndrome Type 3: An update. Indian Pacing Electrophysiol. J. 2018, 18, 25-35. [CrossRef]

341. Remme, C.A. Cardiac sodium channelopathy associated with SCN5A mutations: Electrophysiological, molecular and genetic aspects. J. Physiol. 2013, 591, 4099-4116. [CrossRef] 
342. Riuró, H.; Campuzano, O.; Arbelo, E.; Iglesias, A.; Batlle, M.; Pérez-Villa, F.; Brugada, J.; Pérez, G.J.; Scornik, F.S.; Brugada, R. A missense mutation in the sodium channel $\beta 1 \mathrm{~b}$ subunit reveals SCN1B as a susceptibility gene underlying long QT syndrome. Heart Rhythm 2014, 11, 1202-1209. [CrossRef]

343. Adler, A.; Novelli, V.; Amin, A.S.; Abiusi, E.; Care, M.; Nannenberg, E.A.; Feilotter, H.; Amenta, S.; Mazza, D.; Bikker, H.; et al. An International, Multicentered, Evidence-Based Reappraisal of Genes Reported to Cause Congenital Long QT Syndrome. Circulation 2020, 141, 418-428. [CrossRef]

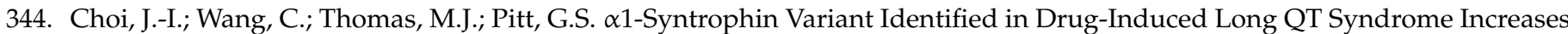
Late Sodium Current. PLOS ONE 2016, 11, e0152355. [CrossRef]

345. Ueda, K.; Valdivia, C.; Medeiros-Domingo, A.; Tester, D.J.; Vatta, M.; Farrugia, G.; Ackerman, M.J.; Makielski, J.C. Syntrophin mutation associated with long QT syndrome through activation of the nNOS-SCN5A macromolecular complex. Proc. Natl. Acad. Sci. USA 2008, 105, 9355-9360. [CrossRef] [PubMed]

346. Wu, G.; Ai, T.; Kim, J.J.; Mohapatra, B.; Xi, Y.; Li, Z.; Abbasi, S.; Purevjav, E.; Samani, K.; Ackerman, M.J.; et al. $\alpha-1-S y n t r o p h i n$ Mutation and the Long-QT Syndrome. Circ. Arrhythmia Electrophysiol. 2008, 1, 193-201. [CrossRef]

347. Hu, R.-M.; Tan, B.-H.; Orland, K.M.; Valdivia, C.R.; Peterson, A.; Pu, J.; Makielski, J.C. Digenic inheritance novel mutations in SCN5A and SNTA1 increase late $I_{N a}$ contributing to LQT syndrome. Am. J. Physiol. Circ. Physiol. 2013, 304, H994-H1001. [CrossRef]

348. Kostera-Pruszczyk, A.; Suszek, M.; Płoski, R.; Franaszczyk, M.; Potulska-Chromik, A.; Pruszczyk, P.; Sadurska, E.; Karolczak, J.; Kamińska, A.M.; Rędowicz, M.J. BAG3-related myopathy, polyneuropathy and cardiomyopathy with long QT syndrome. J. Muscle Res. Cell Motil. 2015, 36, 423-432. [CrossRef]

349. Prondzynski, M.; Lemoine, M.D.; Zech, A.T.; Horváth, A.; Di Mauro, V.; Koivumäki, J.T.; Kresin, N.; Busch, J.; Krause, T.; Krämer E.; et al. Disease modeling of a mutation in $\alpha$-actinin 2 guides clinical therapy in hypertrophic cardiomyopathy. EMBO Mol. Med. 2019, 11, e11115. [CrossRef]

350. Markunas, A.M.; Manivannan, P.K.R.; Ezekian, J.E.; Agarwal, A.; Eisner, W.; Alsina, K.; Allen, H.D.; Wray, G.A.; Kim, J.J.; Wehrens, X.H.T.; et al. TBX5-encoded T-box transcription factor 5 variant T223M is associated with long QT syndrome and pediatric sudden cardiac death. Am. J. Med. Genet. Part A 2021, 185, 923-929. [CrossRef] [PubMed]

351. Nieto-Marín, P.; Tinaquero, D.; Utrilla, R.G.; Cebrián, J.; González-Guerra, A.; Crespo-García, T.; Cámara-Checa, A.; RubioAlarcón, M.; Dago, M.; Alfayate, S.; et al. Tbx5 variants disrupt $\mathrm{Na}_{\mathrm{v}} 1.5$ function differently in patients diagnosed with Brugada or Long QT Syndrome. Cardiovasc. Res. 2021, cvab045. [CrossRef]

352. Splawski, I.; Shen, J.; Timothy, K.W.; Lehmann, M.H.; Priori, S.; Robinson, J.L.; Moss, A.J.; Schwartz, P.J.; Towbin, J.A.; Vincent, G.M.; et al. Spectrum of Mutations in Long-QT Syndrome Genes. Circulation 2000, 102, 1178-1185. [CrossRef]

353. Chung, S.-K.; MacCormick, J.M.; McCulley, C.H.; Crawford, J.; Eddy, C.-A.; Mitchell, E.A.; Shelling, A.N.; French, J.K.; Skinner, J.R.; Rees, M.I. Long QT and Brugada syndrome gene mutations in New Zealand. Heart Rhythm 2007, 4, 1306-1314. [CrossRef]

354. Chang, R.-K.R.; Lan, Y.-T.; Silka, M.J.; Morrow, H.; Kwong, A.; Smith-Lang, J.; Wallerstein, R.; Lin, H.J. Genetic Variants for Long QT Syndrome among Infants and Children from a Statewide Newborn Hearing Screening Program Cohort. J. Pediatr. 2014, 164, 590-595.e3. [CrossRef]

355. Murphy, L.L.; Moon-Grady, A.J.; Cuneo, B.F.; Wakai, R.T.; Yu, S.; Kunic, J.D.; Benson, D.W.; George, A.L. Developmentally regulated SCN5A splice variant potentiates dysfunction of a novel mutation associated with severe fetal arrhythmia. Heart Rhythm 2012, 9, 590-597. [CrossRef]

356. Hu, D.; Barajas-Martínez, H.; Medeiros-Domingo, A.; Crotti, L.; Veltmann, C.; Schimpf, R.; Urrutia, J.; Alday, A.; Casis, O.; Pfeiffer R.; et al. A novel rare variant in SCN1Bb linked to Brugada syndrome and SIDS by combined modulation of $\mathrm{Na}_{\mathrm{v}} 1.5$ and $\mathrm{Kv} 4.3$ channel currents. Heart Rhythm 2012, 9, 760-769. [CrossRef]

357. Rossenbacker, T. Unconventional intronic splice site mutation in SCN5A associates with cardiac sodium channelopathy. J. Med. Genet. 2005, 42, e29. [CrossRef]

358. Casini, S.; Albesa, M.; Wang, Z.; Portero, V.; Ross-Kaschitza, D.; Rougier, J.-S.; Marchal, G.A.; Chung, W.K.; Bezzina, C.R.; Abriel, H.; et al. Functional Consequences of the SCN5A-p.Y1977N Mutation within the PY Ubiquitylation Motif: Discrepancy between HEK293 Cells and Transgenic Mice. Int. J. Mol. Sci. 2019, 20, 5033. [CrossRef]

359. Wang, L.; Han, Z.; Dai, J.; Cao, K. Brugada Syndrome Caused by Sodium Channel Dysfunction Associated with a SCN1B Variant A197V. Arch. Med. Res. 2020, 51, 245-253. [CrossRef]

360. Liu, L.; Hayashi, K.; Kaneda, T.; Ino, H.; Fujino, N.; Uchiyama, K.; Konno, T.; Tsuda, T.; Kawashiri, M.; Ueda, K.; et al. A novel mutation in the transmembrane nonpore region of the $\mathrm{KCNH} 2$ gene causes severe clinical manifestations of long QT syndrome. Heart Rhythm 2013, 10, 61-67. [CrossRef]

361. Rivolta, I.; Abriel, H.; Tateyama, M.; Liu, H.; Memmi, M.; Vardas, P.; Napolitano, C.; Priori, S.G.; Kass, R.S. Inherited Brugada and Long QT-3 Syndrome Mutations of a Single Residue of the Cardiac Sodium Channel Confer Distinct Channel and Clinical Phenotypes. J. Biol. Chem. 2001, 276, 30623-30630. [CrossRef]

362. Liu, H.; Tateyama, M.; Clancy, C.E.; Abriel, H.; Kass, R.S. Channel Openings Are Necessary but not Sufficient for Use-dependent Block of Cardiac $\mathrm{Na}^{+}$Channels by Flecainide. J. Gen. Physiol. 2002, 120, 39-51. [CrossRef]

363. Davis, R.P.; Casini, S.; van den Berg, C.W.; Hoekstra, M.; Remme, C.A.; Dambrot, C.; Salvatori, D.; Oostwaard, D.W.; Wilde, A.A.M.; Bezzina, C.R.; et al. Cardiomyocytes Derived From Pluripotent Stem Cells Recapitulate Electrophysiological Characteristics of an Overlap Syndrome of Cardiac Sodium Channel Disease. Circulation 2012, 125, 3079-3091. [CrossRef] 
364. Zhang, J.; Chen, Y.; Yang, J.; Xu, B.; Wen, Y.; Xiang, G.; Wei, G.; Zhu, C.; Xing, Y.; Li, Y. Electrophysiological and trafficking defects of the SCN5A T353I mutation in Brugada syndrome are rescued by alpha-allocryptopine. Eur. J. Pharmacol. 2015, 746, 333-343. [CrossRef] [PubMed]

365. Ortiz-Bonnin, B.; Rinné, S.; Moss, R.; Streit, A.K.; Scharf, M.; Richter, K.; Stöber, A.; Pfeufer, A.; Seemann, G.; Kääb, S.; et al Electrophysiological characterization of a large set of novel variants in the SCN5A-gene: Identification of novel LQTS3 and BrS mutations. Pflügers Arch.-Eur. J. Physiol. 2016, 468, 1375-1387. [CrossRef]

366. El-Battrawy, I.; Müller, J.; Zhao, Z.; Cyganek, L.; Zhong, R.; Zhang, F.; Kleinsorge, M.; Lan, H.; Li, X.; Xu, Q.; et al. Studying Brugada Syndrome With an SCN1B Variants in Human-Induced Pluripotent Stem Cell-Derived Cardiomyocytes. Front. Cell Dev. Biol. 2019, 7, 261. [CrossRef] [PubMed]

367. Gray, B.; Hasdemir, C.; Ingles, J.; Aiba, T.; Makita, N.; Probst, V.; Wilde, A.A.M.; Newbury-Ecob, R.; Sheppard, M.N.; Semsarian, C.; et al. Lack of genotype-phenotype correlation in Brugada Syndrome and Sudden Arrhythmic Death Syndrome families with reported pathogenic SCN1B variants. Heart Rhythm 2018, 15, 1051-1057. [CrossRef]

368. Ricci, M.T.; Menegon, S.; Vatrano, S.; Mandrile, G.; Cerrato, N.; Carvalho, P.; De Marchi, M.; Gaita, F.; Giustetto, C.; Giachino, D.F. SCN1B gene variants in Brugada Syndrome: A study of 145 SCN5A-negative patients. Sci. Rep. 2015, 4, 6470. [CrossRef]

369. Ogawa, R.; Kishi, R.; Takagi, A.; Sakaue, I.; Takahashi, H.; Matsumoto, N.; Masuhara, K.; Nakazawa, K.; Kobayashi, S.; Miyake, F.; et al. A novel microsatellite polymorphism of sodium channel beta1-subunit gene (SCN1B) may underlie abnormal cardiac excitation manifested by coved-type ST-elevation compatible with Brugada syndrome in Japanese. Int. J. Clin. Pharmacol. Ther. 2010, 48, 109-119. [CrossRef]

370. Olesen, M.S.; Holst, A.G.; Svendsen, J.H.; Haunsø, S.; Tfelt-Hansen, J. SCN1Bb R214Q found in 3 patients: 1 with Brugada syndrome and 2 with lone atrial fibrillation. Heart Rhythm 2012, 9, 770-773. [CrossRef]

371. Peters, S. Arrhythmogenic cardiomyopathy and provocable Brugada ECG in a patient caused by missense mutation in plakophilin2. Int. J. Cardiol. 2014, 173, 317-318. [CrossRef]

372. Forkmann, M.; Tomala, J.; Huo, Y.; Mayer, J.; Christoph, M.; Wunderlich, C.; Salmas, J.; Gaspar, T.; Piorkowski, C. Epicardial Ventricular Tachycardia Ablation in a Patient With Brugada ECG Pattern and Mutation of PKP2 and DSP Genes. Circ. Arrhythmia Electrophysiol. 2015, 8, 505-507. [CrossRef]

373. Kattygnarath, D.; Maugenre, S.; Neyroud, N.; Balse, E.; Ichai, C.; Denjoy, I.; Dilanian, G.; Martins, R.P.; Fressart, V.; Berthet, M.; et al. MOG1. Circ. Cardiovasc. Genet. 2011, 4, 261-268. [CrossRef] [PubMed]

374. Zhou, J.; Wang, L.; Zuo, M.; Wang, X.; Ahmed, A.S.I.; Chen, Q.; Wang, Q.K. Cardiac sodium channel regulator MOG1 regulates cardiac morphogenesis and rhythm. Sci. Rep. 2016, 6, 21538. [CrossRef]

375. Olesen, M.S.; Jensen, N.F.; Holst, A.G.; Nielsen, J.B.; Tfelt-Hansen, J.; Jespersen, T.; Sajadieh, A.; Haunsø, S.; Lund, J.T.; Calloe, K.; et al. A Novel Nonsense Variant in $\mathrm{Na}_{\mathrm{v}} 1.5$ Cofactor MOG1 Eliminates Its Sodium Current Increasing Effect and May Increase the Risk of Arrhythmias. Can. J. Cardiol. 2011, 27, 523.e17-523.e23. [CrossRef] [PubMed]

376. Park, D.S.; Shekhar, A.; Santucci, J.; Redel-Traub, G.; Solinas, S.; Mintz, S.; Lin, X.; Chang, E.W.; Narke, D.; Xia, Y.; et al. Ionic Mechanisms of Impulse Propagation Failure in the FHF2-Deficient Heart. Circ. Res. 2020, 127, 1536-1548. [CrossRef] [PubMed]

377. Schmidt, C.; Wiedmann, F.; El-Battrawy, I.; Fritz, M.; Ratte, A.; Beller, C.J.; Lang, S.; Rudic, B.; Schimpf, R.; Akin, I.; et al. Reduced $\mathrm{Na}^{+}$Current in Native Cardiomyocytes of a Brugada Syndrome Patient Associated With $\beta$-2-Syntrophin Mutation. Circ. Genom. Precis. Med. 2018, 11, e02263. [CrossRef] [PubMed]

378. Shimizu, A.; Zankov, D.P.; Sato, A.; Komeno, M.; Toyoda, F.; Yamazaki, S.; Makita, T.; Noda, T.; Ikawa, M.; Asano, Y.; et al. Identification of transmembrane protein 168 mutation in familial Brugada syndrome. FASEB J. 2020, 34, 6399-6417. [CrossRef] [PubMed]

379. Nguyen, L.K.C.; Shimizu, A.; Soh, J.E.C.; Komeno, M.; Sato, A.; Ogita, H. Transmembrane protein 168 mutation reduces cardiomyocyte cell surface expression of $\mathrm{Na}_{\mathrm{v}} 1.5$ through $\alpha \mathrm{B}$-crystallin intracellular dynamics. J. Biochem. 2021, 170, mvab066. [CrossRef]

380. Di Resta, C.; Pietrelli, A.; Sala, S.; Della Bella, P.; De Bellis, G.; Ferrari, M.; Bordoni, R.; Benedetti, S. High-throughput genetic characterization of a cohort of Brugada syndrome patients. Hum. Mol. Genet. 2015, 24, 5828-5835. [CrossRef]

381. Musa, H.; Marcou, C.A.; Herron, T.J.; Makara, M.A.; Tester, D.J.; O’Connell, R.P.; Rosinski, B.; Guerrero-Serna, G.; Milstein, M.L.; Monteiro da Rocha, A.; et al. Abnormal myocardial expression of SAP97 is associated with arrhythmogenic risk. Am. J. Physiol. Circ. Physiol. 2020, 318, H1357-H1370. [CrossRef]

382. Wang, Z.; Vermij, S.H.; Sottas, V.; Shestak, A.; Ross-Kaschitza, D.; Zaklyazminskaya, E.V.; Hudmon, A.; Pitt, G.S.; Rougier, J.S.; Abriel, H. Calmodulin binds to the N-terminal domain of the cardiac sodium channel $\mathrm{Na}_{\mathrm{v}} 1.5$. Channels 2020, 14, 268-286. [CrossRef]

383. Jiménez-Jáimez, J.; Palomino Doza, J.; Ortega, Á.; Macías-Ruiz, R.; Perin, F.; Rodríguez-Vázquez del Rey, M.M.; Ortiz-Genga, M.; Monserrat, L.; Barriales-Villa, R.; Blanca, E.; et al. Calmodulin 2 Mutation N98S Is Associated with Unexplained Cardiac Arrest in Infants Due to Low Clinical Penetrance Electrical Disorders. PLoS ONE 2016, 11, e0153851. [CrossRef] [PubMed]

384. Yagihara, N.; Watanabe, H.; Barnett, P.; Duboscq-Bidot, L.; Thomas, A.C.; Yang, P.; Ohno, S.; Hasegawa, K.; Kuwano, R.; Chatel, S.; et al. Variants in the SCN5A Promoter Associated with Various Arrhythmia Phenotypes. J. Am. Heart Assoc. 2016, 5, 1-10. [CrossRef]

385. Kimura, Y.; Aiba, T.; Sasano, T.; Furukawa, T.; Kusano, K.; Shimizu, W. IRX3 variant as a modifier of Brugada syndrome with frequent ventricular fibrillation. Heart Case Rep. 2016, 2, 465-468. [CrossRef] 
386. Yang, P.; Koopmann, T.T.; Pfeufer, A.; Jalilzadeh, S.; Schulze-Bahr, E.; Kääb, S.; Wilde, A.A.; Roden, D.M.; Bezzina, C.R. Polymorphisms in the cardiac sodium channel promoter displaying variant in vitro expression activity. Eur. J. Hum. Genet. 2008, 16, 350-357. [CrossRef]

387. Matsumura, H.; Nakano, Y.; Ochi, H.; Onohara, Y.; Sairaku, A.; Tokuyama, T.; Tomomori, S.; Motoda, C.; Amioka, M.; Hironobe, N.; et al. H558R, a common SCN5A polymorphism, modifies the clinical phenotype of Brugada syndrome by modulating DNA methylation of SCN5A promoters. J. Biomed. Sci. 2017, 24, 91. [CrossRef]

388. Scumaci, D.; Oliva, A.; Concolino, A.; Curcio, A.; Fiumara, C.V.; Tammè, L.; Campuzano, O.; Pascali, V.L.; Coll, M.; Iglesias, A.; et al. Integration of "Omics" Strategies for Biomarkers Discovery and for the Elucidation of Molecular Mechanisms Underlying Brugada Syndrome. Proteom.-Clin. Appl. 2018, 12, 1800065. [CrossRef]

389. Aiba, T.; Farinelli, F.; Kostecki, G.; Hesketh, G.G.; Edwards, D.; Biswas, S.; Tung, L.; Tomaselli, G.F. A Mutation Causing Brugada Syndrome Identifies a Mechanism for Altered Autonomic and Oxidant Regulation of Cardiac Sodium Currents. Circ. Cardiovasc. Genet. 2014, 7, 249-256. [CrossRef]

390. Darbar, D.; Kannankeril, P.J.; Donahue, B.S.; Kucera, G.; Stubblefield, T.; Haines, J.L.; George, A.L.J.; Roden, D.M. Cardiac sodium channel (SCN5A) variants associated with atrial fibrillation. Circulation 2008, 117, 1927-1935. [CrossRef]

391. Takehara, N.; Makita, N.; Kawabe, J.; Sato, N.; Kawamura, Y.; Kitabatake, A.; Kikuchi, K. A cardiac sodium channel mutation identified in Brugada syndrome associated with atrial standstill. J. Intern. Med. 2004, 255, 137-142. [CrossRef]

392. Laitinen-Forsblom, P.J.; Makynen, P.; Makynen, H.; Yli-Mayry, S.; Virtanen, V.; Kontula, K.; Aalto-Setala, K. SCN5A Mutation Associated with Cardiac Conduction Defect and Atrial Arrhythmias. J. Cardiovasc. Electrophysiol. 2006, 17, 480-485. [CrossRef]

393. Benito, B.; Brugada, R.; Perich, R.M.; Lizotte, E.; Cinca, J.; Mont, L.; Berruezo, A.; Tolosana, J.M.; Freixa, X.; Brugada, P.; et al A mutation in the sodium channel is responsible for the association of long QT syndrome and familial atrial fibrillation. Heart Rhythm 2008, 5, 1434-1440. [CrossRef]

394. Rossenbacker, T.; Carroll, S.J.; Liu, H.; Kuipéri, C.; de Ravel, T.J.L.; Devriendt, K.; Carmeliet, P.; Kass, R.S.; Heidbüchel, H. Novel pore mutation in SCN5A manifests as a spectrum of phenotypes ranging from atrial flutter, conduction disease, and Brugada syndrome to sudden cardiac death. Heart Rhythm 2004, 1, 610-615. [CrossRef]

395. Watanabe, H.; Darbar, D.; Kaiser, D.W.; Jiramongkolchai, K.; Chopra, S.; Donahue, B.S.; Kannankeril, P.J.; Roden, D.M. Mutations in sodium channel $\beta 1$ - and $\beta 2$-subunits associated with atrial fibrillation. Circ. Arrhythmia Electrophysiol. 2009, 2, $268-275$. [CrossRef] [PubMed]

396. Xiong, H.; Yang, Q.; Zhang, X.; Wang, P.; Chen, F.; Liu, Y.; Wang, P.; Zhao, Y.; Li, S.; Huang, Y.; et al. Significant association of rare variant p.Gly8Ser in cardiac sodium channel $\beta 4$-subunit SCN4B with atrial fibrillation. Ann. Hum. Genet. 2019, 83, 239-248. [CrossRef] [PubMed]

397. Li, R.-G.; Wang, Q.; Xu, Y.-J.; Zhang, M.; Qu, X.-K.; Liu, X.; Fang, W.-Y.; Yang, Y.-Q. Mutations of the SCN4B-encoded sodium channel $\beta 4$ subunit in familial atrial fibrillation. Int. J. Mol. Med. 2013, 32, 144-150. [CrossRef]

398. Wang, P.; Yang, Q.; Wu, X.; Yang, Y.; Shi, L.; Wang, C.; Wu, G.; Xia, Y.; Yang, B.; Zhang, R.; et al. Functional dominant-negative mutation of sodium channel subunit gene SCN3B associated with atrial fibrillation in a Chinese GeneID population. Biochem. Biophys. Res. Commun. 2010, 398, 98-104. [CrossRef] [PubMed]

399. Husser, D.; Ueberham, L.; Hindricks, G.; Büttner, P.; Ingram, C.; Weeke, P.; Shoemaker, M.B.; Adams, V.; Arya, A.; Sommer, P.; et al. Rare variants in genes encoding the cardiac sodium channel and associated compounds and their impact on outcome of catheter ablation of atrial fibrillation. PLoS ONE 2017, 12, e0183690. [CrossRef] [PubMed]

400. Cunha, S.R.; Hund, T.J.; Hashemi, S.; Voigt, N.; Li, N.; Wright, P.; Koval, O.; Li, J.; Gudmundsson, H.; Gumina, R.J.; et al. Defects in Ankyrin-Based Membrane Protein Targeting Pathways Underlie Atrial Fibrillation. Circulation 2011, 124, 1212-1222. [CrossRef]

401. Robaei, D.; Ford, T.; Ooi, S.-Y. Ankyrin-B Syndrome: A Case of Sinus Node Dysfunction, Atrial Fibrillation and Prolonged QT in a Young Adult. Heart Lung Circ. 2015, 24, e31-e34. [CrossRef]

402. Girolami, F.; Iascone, M.; Tomberli, B.; Bardi, S.; Benelli, M.; Marseglia, G.; Pescucci, C.; Pezzoli, L.; Sana, M.E.; Basso, C.; et al Novel $\alpha$-Actinin 2 Variant Associated With Familial Hypertrophic Cardiomyopathy and Juvenile Atrial Arrhythmias. Circ. Cardiovasc. Genet. 2014, 7, 741-750. [CrossRef]

403. LIU, Y.; NI, B.; LIN, Y.; CHEN, X.-G.; CHEN, M.; HU, Z.; ZHANG, F. The rs3807989 G/A Polymorphism in CAV1 is Associated with the Risk of Atrial Fibrillation in Chinese Han Populations. Pacing Clin. Electrophysiol. 2015, 38, 164-170. [CrossRef]

404. Watanabe, H.; Nogami, A.; Ohkubo, K.; Kawata, H.; Hayashi, Y.; Ishikawa, T.; Makiyama, T.; Nagao, S.; Yagihara, N.; Takehara, N.; et al. Electrocardiographic Characteristics and SCN5A Mutations in Idiopathic Ventricular Fibrillation Associated with Early Repolarization. Circ. Arrhythmia Electrophysiol. 2011, 4, 874-881. [CrossRef]

405. Watanabe, H.; Ohkubo, K.; Watanabe, I.; Matsuyama, T.; Ishibashi-Ueda, H.; Yagihara, N.; Shimizu, W.; Horie, M.; Minamino, T.; Makita, N. SCN5A mutation associated with ventricular fibrillation, early repolarization, and concealed myocardial abnormalities. Int. J. Cardiol. 2013, 165, e21-e23. [CrossRef]

406. Reithmann, C.; Beckmann, B.-M.; Kääb, S. Purkinje-related ventricular fibrillation associated with a homozygous H558R polymorphism in the sodium channel SCN5A gene. Europace 2016, 18, 896. [CrossRef] [PubMed]

407. Vilin, Y.; Fujimoto, E.; Ruben, P. A novel mechanism associated with idiopathic ventricular fibrillation (IVF) mutations R1232W and T1620M in human cardiac sodium channels. Pflügers Arch. Eur. J. Physiol. 2001, 442, 204-211. [CrossRef] [PubMed] 
408. Akai, J.; Makita, N.; Sakurada, H.; Shirai, N.; Ueda, K.; Kitabatake, A.; Nakazawa, K.; Kimura, A.; Hiraoka, M. A novel SCN5A mutation associated with idiopathic ventricular fibrillation without typical ECG findings of Brugada syndrome. FEBS Lett. 2000, 479, 29-34. [CrossRef]

409. Wan, X.; Chen, S.; Sadeghpour, A.; Wang, Q.; Kirsch, G.E. Accelerated inactivation in a mutant $\mathrm{Na}^{+}$channel associated with idiopathic ventricular fibrillation. Am. J. Physiol.-Heart Circ. Physiol. 2001, 280, 354-360. [CrossRef] [PubMed]

410. Raharjo, S.B.; Maulana, R.; Maghfirah, I.; Alzahra, F.; Putrinarita, A.D.; Hanafy, D.A.; Yuniadi, Y. SCN 5A gene mutations and the risk of ventricular fibrillation and syncope in Brugada syndrome patients: A meta-analysis. J. Arrhythmia 2018, 34, $473-477$. [CrossRef]

411. Nishii, N.; Ogawa, M.; Morita, H.; Nakamura, K.; Banba, K.; Miura, D.; Kumagai, N.; Matsunaga, A.; Kawamura, H.; Urakawa, S.; et al. SCN5A Mutation Is Associated With Early and Frequent Recurrence of Ventricular Fibrillation in Patients With Brugada Syndrome. Circ. J. 2010, 74, 2572-2578. [CrossRef] [PubMed]

412. KELLER, D.; HUANG, H.; ZHAO, J.; FRANK, R.; SUAREZ, V.; DELACRETAZ, E.; BRINK, M.; OSSWALD, S.; SCHWICK, N.; CHAHINE, M. A novel SCN5A mutation, F1344S, identified in a patient with Brugada syndrome and fever-induced ventricular fibrillation. Cardiovasc. Res. 2006, 70, 521-529. [CrossRef]

413. Kawamura, M.; Ozawa, T.; Yao, T.; Ashihara, T.; Sugimoto, Y.; Yagi, T.; Itoh, H.; Ito, M.; Makiyama, T.; Horie, M. Dynamic Change in ST-Segment and Spontaneous Occurrence of Ventricular Fibrillation in Brugada Syndrome With a Novel Nonsense Mutation in the SCN5A Gene During Long-Term Follow-up. Circ. J. 2009, 73, 584-588. [CrossRef]

414. Lieve, K.V.; Verkerk, A.O.; Podliesna, S.; van der Werf, C.; Tanck, M.W.; Hofman, N.; van Bergen, P.F.; Beekman, L.; Bezzina, C.R.; Wilde, A.A.M.; et al. Gain-of-function mutation in SCN5A causes ventricular arrhythmias and early onset atrial fibrillation. Int. J. Cardiol. 2017, 236, 187-193. [CrossRef] [PubMed]

415. Boehringer, T.; Bugert, P.; Borggrefe, M.; Elmas, E. SCN5A mutations and polymorphisms in patients with ventricular fibrillation during acute myocardial infarction. Mol. Med. Rep. 2014, 10, 2039-2044. [CrossRef]

416. Wang, F.; Liu, Y.; Liao, H.; Xue, Y.; Zhan, X.; Fang, X.; Liang, Y.; Wei, W.; Rao, F.; Zhang, Q.; et al. Genetic Variants on SCN5A, KCNQ1, and KCNH2 in Patients with Ventricular Arrhythmias during Acute Myocardial Infarction in a Chinese Population. Cardiology 2020, 145, 38-45. [CrossRef]

417. Hu, D.; Viskin, S.; Oliva, A.; Carrier, T.; Cordeiro, J.M.; Barajas-Martinez, H.; Wu, Y.; Burashnikov, E.; Sicouri, S.; Brugada, R.; et al. Novel mutation in the SCN5A gene associated with arrhythmic storm development during acute myocardial infarction. Heart Rhythm 2007, 4, 1072-1080. [CrossRef]

418. Ter Bekke, R.M.A.; Isaacs, A.; Barysenka, A.; Hoos, M.B.; Jongbloed, J.D.H.; Hoorntje, J.C.A.; Patelski, A.S.M.; Helderman-van den Enden, A.T.J.M.; van den Wijngaard, A.; Stoll, M.; et al. Heritability in a SCN5A -mutation founder population with increased female susceptibility to non-nocturnal ventricular tachyarrhythmia and sudden cardiac death. Heart Rhythm 2017, 14, 1873-1881. [CrossRef] [PubMed]

419. Son, M.K.; Ki, C.-S.; Park, S.-J.; Huh, J.; Kim, J.S.; On, Y.K. Genetic Mutation in Korean Patients of Sudden Cardiac Arrest as a Surrogating Marker of Idiopathic Ventricular Arrhythmia. J. Korean Med. Sci. 2013, 28, 1021. [CrossRef] [PubMed]

420. Stawiarski, K.; Clarke, J.-R.D.; Pollack, A.; Winslow, R.; Majumdar, S. Ventricular fibrillation in Graves disease reveals a rare SCN5A mutation with W1191X variant associated with Brugada syndrome. Heart Case Rep. 2021, 7, 95-99. [CrossRef]

421. Valdivia, C.R.; Medeiros-Domingo, A.; Ye, B.; Shen, W.K.; Algiers, T.J.; Ackerman, M.J.; Makielski, J.C. Loss-of-function mutation of the SCN3B-encoded sodium channel 3 subunit associated with a case of idiopathic ventricular fibrillation. Cardiovasc. Res. 2010, 86, 392-400. [CrossRef]

422. Lasam, G.; Oaks, J.B. A Rare Desmoglein-2 Gene Mutation in Arrhythmogenic Right Ventricular Cardiomyopathy Inciting Incessant Ventricular Fibrillation. Cureus 2018, 10, e3388. [CrossRef]

423. Rigato, I.; Bauce, B.; Rampazzo, A.; Zorzi, A.; Pilichou, K.; Mazzotti, E.; Migliore, F.; Marra, M.P.; Lorenzon, A.; De Bortoli, M.; et al. Compound and Digenic Heterozygosity Predicts Lifetime Arrhythmic Outcome and Sudden Cardiac Death in Desmosomal Gene-Related Arrhythmogenic Right Ventricular Cardiomyopathy. Circ. Cardiovasc. Genet. 2013, 6, 533-542. [CrossRef]

424. Bhonsale, A.; Groeneweg, J.A.; James, C.A.; Dooijes, D.; Tichnell, C.; Jongbloed, J.D.H.; Murray, B.; te Riele, A.S.J.M.; van den Berg, M.P.; Bikker, H.; et al. Impact of genotype on clinical course in arrhythmogenic right ventricular dysplasia/cardiomyopathyassociated mutation carriers. Eur. Heart J. 2015, 36, 847-855. [CrossRef] [PubMed]

425. Cox, M.G.P.J.; van der Zwaag, P.A.; van der Werf, C.; van der Smagt, J.J.; Noorman, M.; Bhuiyan, Z.A.; Wiesfeld, A.C.P.; Volders, P.G.A.; van Langen, I.M.; Atsma, D.E.; et al. Arrhythmogenic Right Ventricular Dysplasia/Cardiomyopathy. Circulation 2011, 123, 2690-2700. [CrossRef] [PubMed]

426. Marsman, R.F.; Barc, J.; Beekman, L.; Alders, M.; Dooijes, D.; van den Wijngaard, A.; Ratbi, I.; Sefiani, A.; Bhuiyan, Z.A.; Wilde, A.A.M.; et al. A Mutation in CALM1 Encoding Calmodulin in Familial Idiopathic Ventricular Fibrillation in Childhood and Adolescence. J. Am. Coll. Cardiol. 2014, 63, 259-266. [CrossRef]

427. Nomikos, M.; Thanassoulas, A.; Beck, K.; Vassilakopoulou, V.; Hu, H.; Calver, B.L.; Theodoridou, M.; Kashir, J.; Blayney, L.; Livaniou, E.; et al. Altered RyR2 regulation by the calmodulin F90L mutation associated with idiopathic ventricular fibrillation and early sudden cardiac death. FEBS Lett. 2014, 588, 2898-2902. [CrossRef]

428. Bagnall, R.D.; Molloy, L.K.; Kalman, J.M.; Semsarian, C. Exome sequencing identifies a mutation in the ACTN2 gene in a family with idiopathic ventricular fibrillation, left ventricular noncompaction, and sudden death. BMC Med. Genet. 2014, 15, 99. [CrossRef] 
429. Butters, T.D.; Aslanidi, O.V.; Inada, S.; Boyett, M.R.; Hancox, J.C.; Lei, M.; Zhang, H. Mechanistic Links Between Na ${ }^{+}$Channel (SCN5A) Mutations and Impaired Cardiac Pacemaking in Sick Sinus Syndrome. Circ. Res. 2010, 107, 126-137. [CrossRef]

430. GUI, J.; WANG, T.; TRUMP, D.; ZIMMER, T.; LEI, M. Mutation-Specific Effects of Polymorphism H558R in SCN5A-Related Sick Sinus Syndrome. J. Cardiovasc. Electrophysiol. 2010, 21, 564-573. [CrossRef] [PubMed]

431. Abe, K.; Machida, T.; Sumitomo, N.; Yamamoto, H.; Ohkubo, K.; Watanabe, I.; Makiyama, T.; Fukae, S.; Kohno, M.; Harrell, D.T.; et al. Sodium Channelopathy Underlying Familial Sick Sinus Syndrome With Early Onset and Predominantly Male Characteristics. Circ. Arrhythmia Electrophysiol. 2014, 7, 511-517. [CrossRef]

432. Nakajima, S.; Makiyama, T.; Hanazawa, K.; Kaitani, K.; Amano, M.; Hayama, Y.; Onishi, N.; Tamaki, Y.; Miyake, M.; Tamura, T.; et al. A Novel SCN5A Mutation Demonstrating a Variety of Clinical Phenotypes in Familial Sick Sinus Syndrome. Intern. Med. 2013, 52, 1805-1808. [CrossRef] [PubMed]

433. Tan, B.; Iturraldetorres, P.; Medeirosdomingo, A.; Nava, S.; Tester, D.; Valdivia, C.; Tusieluna, T.; Ackerman, M.; Makielski, J. A novel C-terminal truncation $S C N 5 A$ mutation from a patient with sick sinus syndrome, conduction disorder and ventricular tachycardia. Cardiovasc. Res. 2007, 76, 409-417. [CrossRef]

434. Kodama, T.; Serio, A.; Disertori, M.; Bronzetti, G.; Diegoli, M.; Narula, N.; Grasso, M.; Mazzola, S.; Arbustini, E. Autosomal recessive paediatric sick sinus syndrome associated with novel compound mutations in SCN5A. Int. J. Cardiol. 2013, 167, 3078-3080. [CrossRef] [PubMed]

435. Holst, A.G.; Liang, B.; Jespersen, T.; Bundgaard, H.; Haunso, S.; Svendsen, J.H.; Tfelt-Hansen, J. Sick Sinus Syndrome, Progressive Cardiac Conduction Disease, Atrial Flutter and Ventricular Tachycardia Caused by a Novel SCN5A Mutation. Cardiology 2010, 115, 311-316. [CrossRef] [PubMed]

436. Alkorashy, M.; Al-Ghamdi, B.; Tulbah, S.; Al-Numair, N.S.; Alhadeq, F.; Takroni, S.A.; Al-Hassnan, Z.N. A novel homozygous SCN5A variant detected in sick sinus syndrome. Pacing Clin. Electrophysiol. 2021, 44, 380-384. [CrossRef] [PubMed]

437. Ziyadeh-Isleem, A.; Clatot, J.; Duchatelet, S.; Gandjbakhch, E.; Denjoy, I.; Hidden-Lucet, F.; Hatem, S.; Deschênes, I.; Coulombe, A.; Neyroud, N.; et al. A truncating SCN5A mutation combined with genetic variability causes sick sinus syndrome and early atrial fibrillation. Heart Rhythm 2014, 11, 1015-1023. [CrossRef] [PubMed]

438. Ackerman, M.J. Postmortem Molecular Analysis of SCN5A Defects in Sudden Infant Death Syndrome. JAMA 2001, $286,2264$. [CrossRef]

439. Wang, D.W.; Desai, R.R.; Crotti, L.; Arnestad, M.; Insolia, R.; Pedrazzini, M.; Ferrandi, C.; Vege, A.; Rognum, T.; Schwartz, P.J.; et al. Cardiac Sodium Channel Dysfunction in Sudden Infant Death Syndrome. Circulation 2007, 115, 368-376. [CrossRef]

440. Turillazzi, E.; La Rocca, G.; Anzalone, R.; Corrao, S.; Neri, M.; Pomara, C.; Riezzo, I.; Karch, S.B.; Fineschi, V. Heterozygous nonsense SCN5A mutation W822X explains a simultaneous sudden infant death syndrome. Virchows Arch. 2008, 453, 209-216. [CrossRef]

441. Van Norstrand, D.W.; Tester, D.J.; Ackerman, M.J. Overrepresentation of the proarrhythmic, sudden death predisposing sodium channel polymorphism S1103Y in a population-based cohort of African-American sudden infant death syndrome. Heart Rhythm 2008, 5, 712-715. [CrossRef]

442. Wedekind, H.; Smits, J.P.P.; Schulze-Bahr, E.; Arnold, R.; Veldkamp, M.W.; Bajanowski, T.; Borggrefe, M.; Brinkmann, B.; Warnecke, I.; Funke, H.; et al. De Novo Mutation in the SCN5A Gene Associated With Early Onset of Sudden Infant Death. Circulation 2001, 104, 1158-1164. [CrossRef]

443. Plant, L.D. A common cardiac sodium channel variant associated with sudden infant death in African Americans, SCN5A S1103Y. J. Clin. Investig. 2006, 116, 430-435. [CrossRef]

444. Todd, S.J.; Campbell, M.J.; Roden, D.M.; Kannankeril, P.J. Novel Brugada SCN5A mutation causing sudden death in children. Heart Rhythm 2005, 2, 540-543. [CrossRef] [PubMed]

445. Neubauer, J.; Rougier, J.-S.; Abriel, H.; Haas, C. Functional implications of a rare variant in the sodium channel $\beta 1 B$ subunit (SCN1B) in a 5-month-old male sudden infant death syndrome case. Heart Case Rep. 2018, 4, 187-190. [CrossRef]

446. Tan, B.-H.; Pundi, K.N.; Van Norstrand, D.W.; Valdivia, C.R.; Tester, D.J.; Medeiros-Domingo, A.; Makielski, J.C.; Ackerman, M.J. Sudden infant death syndrome-associated mutations in the sodium channel beta subunits. Heart Rhythm 2010, 7, 771-778. [CrossRef]

447. Denti, F.; Bentzen, B.H.; Wojciak, J.; Thomsen, N.M.; Scheinman, M.; Schmitt, N. Multiple genetic variations in sodium channel subunits in a case of sudden infant death syndrome. Pacing Clin. Electrophysiol. 2018, 41, 620-626. [CrossRef]

448. Winkel, B.G.; Yuan, L.; Olesen, M.S.; Sadjadieh, G.; Wang, Y.; Risgaard, B.; Jabbari, R.; Haunsø, S.; Holst, A.G.; Hollegaard, M.V.; et al. The role of the sodium current complex in a nonreferred nationwide cohort of sudden infant death syndrome. Heart Rhythm 2015, 12, 1241-1249. [CrossRef]

449. Makita, N.; Yagihara, N.; Crotti, L.; Johnson, C.N.; Beckmann, B.-M.; Roh, M.S.; Shigemizu, D.; Lichtner, P.; Ishikawa, T.; Aiba, T.; et al. Novel Calmodulin Mutations Associated With Congenital Arrhythmia Susceptibility. Circ. Cardiovasc. Genet. 2014, 7, 466-474. [CrossRef] [PubMed]

450. Cheng, J.; Van Norstrand, D.W.; Medeiros-Domingo, A.; Tester, D.J.; Valdivia, C.R.; Tan, B.-H.; Vatta, M.; Makielski, J.C.; Ackerman, M.J. LQTS-associated mutation A257G in $\alpha 1$-syntrophin interacts with the intragenic variant P74L to modify its biophysical phenotype. Cardiogenetics 2011, 1, 13. [CrossRef] [PubMed]

451. Cronk, L.B.; Ye, B.; Kaku, T.; Tester, D.J.; Vatta, M.; Makielski, J.C.; Ackerman, M.J. Novel mechanism for sudden infant death syndrome: Persistent late sodium current secondary to mutations in caveolin-3. Heart Rhythm 2007, 4, 161-166. [CrossRef] 
452. Veltmann, C.; Barajas-Martinez, H.; Wolpert, C.; Borggrefe, M.; Schimpf, R.; Pfeiffer, R.; Cáceres, G.; Burashnikov, E.; Antzelevitch, C.; Hu, D. Further Insights in the Most Common SCN5A Mutation Causing Overlapping Phenotype of Long QT Syndrome, Brugada Syndrome, and Conduction Defect. J. Am. Heart Assoc. 2016, 5, 1-15. [CrossRef] [PubMed]

453. Kyndt, F.; Probst, V.; Potet, F.; Demolombe, S.; Chevallier, J.C.; Baro, I.; Moisan, J.P.; Boisseau, P.; Schott, J.J.; Escande, D.; et al. Novel SCN5A mutation leading either to isolated cardiac conduction defect or Brugada syndrome in a large French family. Circulation 2001, 104, 3081-3086. [CrossRef]

454. Hothi, S.S.; Ara, F.; Timperley, J. p.Y1449C SCN5A Mutation Associated with Overlap Disorder Comprising Conduction Disease, Brugada Syndrome, and Atrial Flutter. J. Cardiovasc. Electrophysiol. 2015, 26, 93-97. [CrossRef]

455. Chen, S. SNP S1103Y in the cardiac sodium channel gene SCN5A is associated with cardiac arrhythmias and sudden death in a white family. J. Med. Genet. 2002, 39, 913-915. [CrossRef] [PubMed]

456. Márquez, M.F.; Cruz-Robles, D.; Inés-Real, S.; Gallardo, G.J.; Gonzlez-Hermosillo, A.; Cárdenas, M.; Vargas-Alarcón, G. A novel SCN5A deletion mutation in a child with ventricular tachycardia, recurrent aborted sudden death, and Brugada electrocardiographic pattern. Arch. Cardiol. Mex. 2007, 77, 284-287. [PubMed]

457. Patel, C.; Silcock, L.; McMullan, D.; Brueton, L.; Cox, H. TBX5 intragenic duplication: A family with an atypical Holt-Oram syndrome phenotype. Eur. J. Hum. Genet. 2012, 20, 863-869. [CrossRef] 